\title{
Análise dos genes LIN28B, KISS1 e KISS1R em crianças com puberdade precoce central idiopática
}

Dissertação apresentada à Faculdade de Medicina da Universidade de São Paulo para obtenção do título de Mestre em Ciências

Programa de: Ciências Médicas

Área de concentração: Distúrbios Genéticos de Desenvolvimento e Metabolismo

Orientadora: Profa. Dra. Ana Claudia Latronico

São Paulo 
Dados Internacionais de Catalogação na Publicação (CIP)

Preparada pela Biblioteca da

Faculdade de Medicina da Universidade de São Paulo

Creprodução autorizada pelo autor

\section{Silveira-Neto, Acácio Pinto da}

Análise dos genes LIN28B, KISS1 e KISS1R em crianças com puberdade precoce central idiopática / Acácio Pinto da Silveira Neto. -- São Paulo, 2011.

Dissertação(mestrado)--Faculdade de Medicina da Universidade de São Paulo. Programa de Ciências Médicas. Área de concentração: Distúrbios Genéticos de Desenvolvimento e Metabolismo.

Orientadora: Ana Claudia Latronico.

Descritores: 1.Puberdade precoce 2.Hormônio liberador de gonadotropina 3.Gonadotropinas 4.Sistema hipotálamo-hipofisário 5.Receptor KISS1R 6.LIN28B

USP/FM/DBD-263/11 
Este trabalho foi desenvolvido na Unidade de Endocrinologia do Desenvolvimento, Laboratório de Hormônios e Genética Molecular LIM/42 da Disciplina de Endocrinologia do Hospital das Clínicas da Faculdade de Medicina da Universidade de São Paulo 


\section{DEDICATÓRIA}


Agradeço aos meus pais Luiz e Iracy que nunca mediram esforços para que eu pudesse realizar minha formação acadêmica e sempre serão para mim motivo de orgulho e exemplo de vida. 
À minha namorada Camila e sua família por preencherem de amor e felicidade os meus dias, trazendo-me tranqüilidade e maturidade para vencer os desafios. 


\section{AGRADECIMENTOS}

À Profa. Dra. Ana Claudia Latronico pela oportunidade concedida, ensinamentos e inestimável orientação e amizade durante a realização deste trabalho. Exemplo de profissionalismo e seriedade a ser seguido.

À Profa. Dra. Berenice B. de Mendonça por seu exemplo de profissionalismo e amizade, por ter me acolhido em seu serviço e possibilitado que eu realizasse este trabalho.

À Dra. Letícia Ferreira Gontijo Silveira pela co-orientação, ensinamentos, críticas construtivas, sugestões e por sua amizade.

À mestranda Daiane Beneduzzi (dos Santos) pela inestimável ajuda na realização de experimentos, pela valiosa amizade e companheirismo, sempre disposta à ajudar.

Ao Prof. Dr. Richard Gregory, chefe do Departament of Biological Chemistry and Molecular Pharmacology, Harvard Medical School, Boston, EUA, pela realização dos estudos funcionais deste trabalho.

À Dra. Milena Teless e À Dra. Priscilla Cukier pela ajuda na organização da casuística de pacientes de puberdade precoce.

À Dra. Maria Escobar, do centro de Investigações Endocrinológicas do Hospital de Niños Ricardo Gutiérrez, Buenos Aires, por ter selecionado pacientes de puberdade precoce.

Ao Prof. Dr. Vinícius Brito pelas análises estatísticas, sugestões e amizade. 
Aos queridos amigos do Laboratório de Hormônios e Genética Molecular LIM/42: Ricardo Paranhos, Cintia Tusset, Vivian Moura, Gisele Yuri, Tathiana Silva, Lucas Moura, Fabiana Mendez, Michele Moreira, Regina Matsunaga, Ricardo Araújo e Laura Kaupert pela agradável convivência durante a realização deste trabalho.

À Dra. Elaine Costa pelas agradáveis discussões sobre o "projeto por água abaixo", do zebrafish.

À Dra. Miriam Nishi, Dra. Ericka Trarbach e Mariana Funari por terem me ensinado e compartilhado conhecimentos valiosos na área da biologia molecular.

Às funcionárias Nilda, Fran, Cristina, Cidinha, Rosana e Cristiane pela competência, generosidade e dedicação que são fundamentais para o bom funcionamento das atividades no LIM/42.

À minha irmã Francine e aos tios Frank e Henny pelo apoio, carinho e incentivo em todas as horas.

Ao amigo Bino Lanna pelo companheirismo na reta final deste trabalho.

À instituição de fomento FAPESP (bolsa de mestrado, processo 08/55953-4, projeto temático, processo 05/04726-0), pelo apoio financeiro durante a realização deste trabalho.

À todos os funcionários do LIM42 e aqueles que, direta ou indiretamente, contribuíram para a realização deste trabalho. 


\section{SUMÁRIO}

Lista de Abreviaturas

Lista de Figuras

Lista de Tabelas

Resumo

Summary

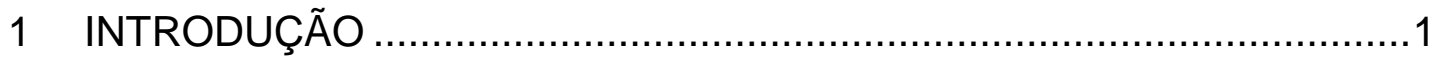

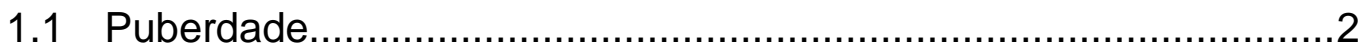

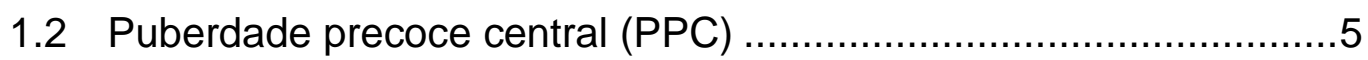

1.3 Kisspeptinas e seu receptor KISS1R ....................................6

1.3.1 Estrutura gênica e protéica/ via de sinalização intracelular....6

1.3.2 Regulação do eixo gonadotrófico .................................11

1.3.3 Mutações inativadoras no gene KISS1R associadas ao hipogonadismo hipogonadotrófico.............................17

1.3.4 Mutações ativadoras nos genes KISS1R e KISS1 associadas à puberdade precoce central ......................19

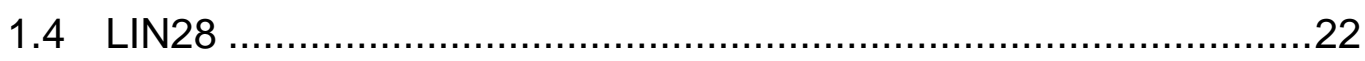

1.4.1 Lin28B e puberdade ........................................... 22

1.4.2 Estrutura gênica e protéica.......................................24

1.4.3 Lin28 regula o tempo de desenvolvimento em Caenorhabditis elegans.............................................25

1.4.4 LIN28 e sua associação com miRNAs ..........................27

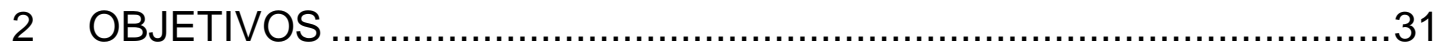

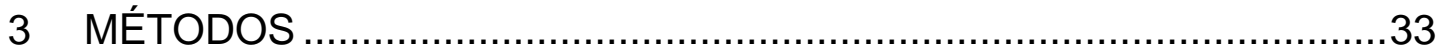

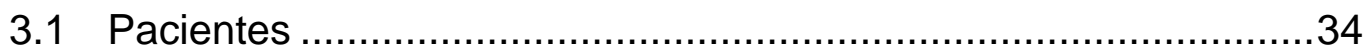

3.2 Avaliação hormonal.......................................................... 36

3.3 Pesquisa de mutações......................................................42

3.3.1 Extração do DNA genômico de leucócitos a partir de sangue periférico

3.3.2 Amplificação de DNA genômico por reação em cadeia da polimerase (PCR) ..............................................43

3.3.3 Sequenciamento automático ....................................45

3.3.4 Análise estatística dos polimorfismos..........................46

3.3.5 Predição de mudança de sítio de splicing .......................46

3.3.6 Digestão por enzima de restrição ..............................47 


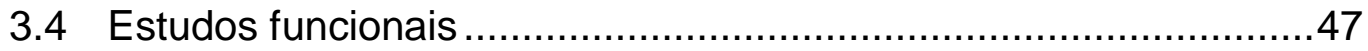

3.4.1- Clonagem e mutagênese sítio-dirigida ...........................48

3.4.2- Cultura celular e transfecção ......................................48

3.4.3- Imunoprecipitação, Western Blotting e EMSA ...................48

3.4.4- Extração de RNA e PCR em Tempo Real ..........................49

3.4.5- Ensaio de luciferase ...............................................49

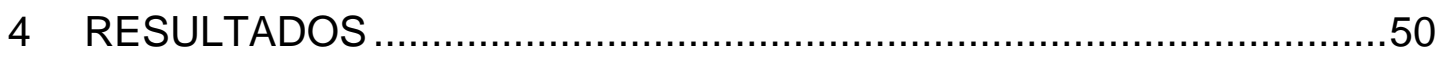

4.1 Pesquisa de mutações e polimorfismos no gene KISS1 .................51

4.2 Pesquisa de mutações e polimorfismos no gene KISS1R .............56

4.3 Pesquisa de mutações e polimorfismos no gene LIN28B .............58

4.3.1 Apresentação clínica da paciente portadora da variante p.H199R do LIN28B ...........................................59

4.4 Estudos funcionais .................................................... 61

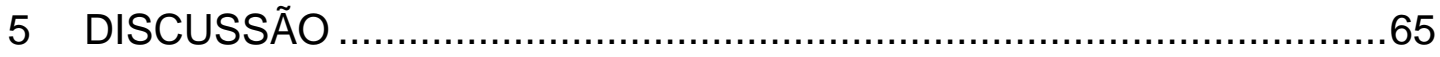

5.1 Variante p.H9OD no gene KISS1 ........................................69

5.2 Polimorfismos no gene KISS1.......................................... 70

5.3 Variante p.H199R no gene LIN28B ................................. 72

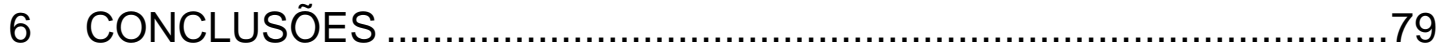

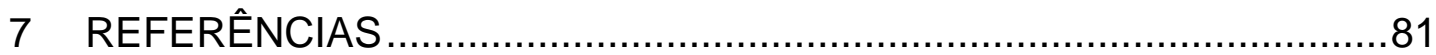




\section{LISTA DE ABREVIATURAS}

\begin{tabular}{|c|c|}
\hline aa & Aminoácido \\
\hline AR & Receptor de andrógenos \\
\hline ARC & Núcleo arqueado \\
\hline AVPV & Núcleo paraventricular anteroventral \\
\hline $\mathrm{CCHC}$ & Cisteína-Cisteína-Histidina-Cisteína \\
\hline cDNA & DNA complementar \\
\hline ChIP & Imunoprecipitação da cromatina \\
\hline $\mathrm{CHO}$ & Células derivadas de ovário de hamster chinês \\
\hline $\mathrm{CHO}-\mathrm{K} 1$ & $\begin{array}{l}\text { Células derivadas de ovário de hamster chinês que } \\
\text { expressam KISS1R }\end{array}$ \\
\hline COS-7 & Células derivadas de rim de macaco verde africanc \\
\hline $\mathrm{COOH}$ & Carboxiterminal \\
\hline $\mathrm{CRH}$ & Hormônio liberador de corticotrofina \\
\hline CSD & Domínio de choque frio \\
\hline DAG & Diacilglicerol \\
\hline dNTP & Desoxirribonucleotídeos \\
\hline DP & Desvio-padrão \\
\hline $\mathrm{E}$ & Estatura \\
\hline$E_{2}$ & Estradiol \\
\hline EA & Estatura alvo \\
\hline EDTA & Ácido etilenodiamino tetracético \\
\hline EGF & Fator de crescimento epidérmico \\
\hline EMSA & Ensaio de retardo da mobilidade eletroforética \\
\hline ER- $\alpha$ & Receptor alfa de estrógeno \\
\hline ERK 1 & Quinase regulada por sinal extracelular 1 \\
\hline ERK 2 & Quinase regulada por sinal extracelular 2 \\
\hline $\mathrm{FSH}$ & Hormônio folículo-estimulante \\
\hline GABA & Ácido gama-aminobutírico \\
\hline
\end{tabular}




$\begin{array}{ll}\text { GnRH } & \text { Hormônio liberador de gonadotropinas } \\ \text { GPR54 } & \text { Receptor acoplado a proteína G-54 } \\ \text { GWAS } & \text { Estudos de associação ampla do genoma } \\ \text { G2 } & \text { Fase G2 do ciclo celular } \\ \text { HCl } & \text { Ácido clorídrico } \\ \text { HEK-293 } & \text { Células derivadas de rim embrionário humano } \\ \text { HHI } & \text { Hipogonadismo hipogonadotrófico isolado } \\ \text { HHG } & \text { Eixo hipotálamo-hipófise-gonadal } \\ \text { Huh7 } & \text { Células de hepatocarcinoma humano } \\ \text { IC } & \text { Idade cronológica } \\ \text { ICV } & \text { Intracerebroventricular } \\ \text { IE } & \text { Idade estatural } \\ \text { IFMA } & \text { Ensaio imunofluorimétrico } \\ \text { IL-1 } & \text { Interleucina 1 } \\ \text { IL-6 } & \text { Interleucina 6 } \\ \text { Indel } & \text { Inserção e deleção de um ou mais nucleotídeos } \\ \text { IO } & \text { Idade óssea } \\ \text { IP } 3 & \text { Inositol 1,4,5 trifosfato } \\ \text { kb } & \text { kilobases } \\ \text { KDa } & \text { Kilodalton } \\ \text { Kiss1+/+ } & \text { Modelo murino que expressa o gene Kiss1 } \\ \text { Kiss1-/- } & \text { Knockout do gene Kiss1 murino } \\ \text { KISS1R } & \text { Receptor de kisspeptina } \\ \text { Kiss1R-/- } & \text { Knockout do gene Kiss1R murino } \\ \text { KP } & \text { Kisspeptina } \\ \text { Kp54-wt } & \text { Kisspeptina selvagem } \\ \text { Kp54-P74S } & \text { Kisspeptina mutante P74S } \\ \text { L } & \text { Estágio larval do Caenorhabditis elegans } \\ \text { LH } & \text { Hormônio luteinizante } \\ \text { MAP } & \text { Proteínas ativadas por mitógenos } \\ \text { MEK } & \text { Quinase regulada por metiletilcetona-mitógeno }\end{array}$




\begin{tabular}{|c|c|}
\hline $\mathrm{MgCl}_{2}$ & Cloreto de magnésio \\
\hline MREs & Elementos reconhecidos por miRNA \\
\hline miRNA & Micro RNA \\
\hline $\mathrm{NaCl}$ & Cloreto de sódio \\
\hline $\mathrm{NCBI}$ & National Center for Biotechnology and Information \\
\hline $\mathrm{NH}_{2}$ & Aminoterminal \\
\hline NPY & Neuropeptídeo Y \\
\hline OVX & Ovariectomia \\
\hline $\mathrm{pb}$ & Pares de base \\
\hline PCR & Reação em cadeia da polimerase \\
\hline $\mathrm{PeN}$ & Núcleo periventricular \\
\hline pERK & Quinase regulada por sinal extracelular fosforilada \\
\hline $\mathrm{PIP}_{2}$ & fosfatidilinositol 4,5 difosfato \\
\hline PKC & Proteína quinase C \\
\hline PLC & Fosfolipase C \\
\hline POA & Área pré-óptica \\
\hline PP & Pêlos pubianos \\
\hline PPC & Puberdade precoce central \\
\hline PPP & Puberdade precoce periférica \\
\hline PR & Receptor de prolactina \\
\hline Pré-miRNA & Precursor do miRNA maduro \\
\hline Pri-miRNA & Micro RNA primário \\
\hline RCCP & $\begin{array}{l}\text { Atraso constitucional de crescimento e desenvolvimento } \\
\text { puberal }\end{array}$ \\
\hline RF-amida & Arginina e fenilalanina ligada a um grupo amida \\
\hline RIE & Radioimunoensaio \\
\hline RISC & Complexo silenciador induzido pelo RNA \\
\hline RM & Ressonância magnética \\
\hline RNAm & RNA mensageiro \\
\hline rpm & Rotações por minuto \\
\hline RT-PCR & Reação em cadeia da polimerase via transcriptase reversa \\
\hline
\end{tabular}


$\mathrm{S}$

SDS

SNC

SNP

SP1

$\mathrm{T}$

TE

TGF- $\alpha$

TGF- $\beta$

Tris

TTF1

TUTase

up-miRNA

VIP

$\chi^{2}$

Z

ZFD
Fase $\mathrm{S}$ do ciclo celular

Sulfato dodecil de sódio

Sistema nervoso central

Polimorfismo de nucleotídeo único

Proteína da especificidade 1

Testosterona

Tampão de Tris e EDTA

Fator de transformação de crescimento $\alpha$

Fator de transformação de crescimento $\beta$

Trisaminometano

Fator de transcrição tireoidiano 1

$3 `$ terminal uridil transferase

MicroRNA uridilado

Peptídeo intestinal vasoativo

Qui-quadrado

Desvio padrão

Domínio de dedos de zinco 


\section{LISTA DE FIGURAS}

Figura 1. Representação esquemática da secreção de $\mathrm{GnRH}$ ao longo da vida

Figura 2. Representação esquemática do gene KISS1, contendo três exons, e seus produtos protéicos, as kisspeptinas.

Figura 3. Cascata de sinalização da kisspeptina 10

Figura 4. Alinhamento da sequência de amino ácidos da kisspeptina de diferentes espécies de mamíferos.

Figura 5. Modelo dos processos de maturação e regulação do microRNA let-7.

Figura 6. Eletroferograma mostrando a substituição de uma citosina por uma guanina em homozigose no exon 3 do gene KISS1 (c.422C>G), em comparação com uma sequência normal

Figura 7. Eletroferograma mostrando as variantes polimórficas identificadas nos três exons do gene KISS1, incluindo regiões codificadoras e não traduzidas

Figura 8. Eletroferograma mostrando as variantes polimórficas identificadas na região promotora do gene KISS1

Figura 9. Eletroferograma mostrando as variantes polimórficas identificadas nos cinco exons do gene KISS1R, incluindo regiões codificadoras e não traduzidas

Figura 10. Eletroferograma mostrando a substituição de uma adenina por uma guanina em heterozigose no exon 4 do gene LIN28B (c.799A>G), em comparação com uma sequência normal

Figura 11. Eletroferograma mostrando a substituição de uma timina por uma citosina em heterozigose no íntron 2 do gene LIN28B (IVS2-118T>C), em comparação com uma sequência normal..59 
Figura 12. Análise por Western Blotting das proteínas LIN28B e LIN28B H199R imunopurificadas com anticorpo anti-Flag....

Figura 13. EMSA realizado com pré-let-7 e quantidades crescentes de proteínas LIN28B e LIN28B H199R imunopurificadas com anticorpo anti-Flag

Figura 14. Análise por PCR em Tempo Real da expressão de let-7g maduro em células HEK293

Figura 15. Ensaio da atividade de luciferase através de um gene repórter responsivo a let-7 


\section{LISTA DE TABELAS}

Tabela 1. Dados clínicos dos pacientes do sexo feminino com PPC. .......37

Tabela 2. Dados clínicos dos pacientes do sexo masculino com PPC .....40

Tabela 3. Valores normais de testosterona e LH no sexo masculino, obtidos nos ensaios IFMA e RIE em pré-púberes e adultos ......41

Tabela 4. Valores normais de estradiol e LH no sexo feminino, obtidos nos ensaios de IFMA e RIE em pré-púberes e adultos.

Tabela 5. Oligonucleotídeos utilizados para amplificação dos genes KISS1, KISS1R e LIN28B

Tabela 6. Frequência alélica dos polimorfismos identificados nos exons 1 a 3 do gene KISS1 em pacientes com PPC e controles.

Tabela 7. Frequência genotípica dos polimorfismos identificados nos exons 1 a 3 do gene KISS1 em pacientes com PPC e controles

Tabela 8. Frequência alélica dos polimorfismos identificados na região promotora do gene KISS1 em pacientes com PPC e controles

Tabela 9. Frequência genotípica dos polimorfismos identificados na região promotora do gene KISS1 em pacientes com PPC e controles

Tabela 10. Frequência alélica dos polimorfismos identificados no gene KISS1R em pacientes com PPC

Tabela 11. Frequência genotípica dos polimorfismos identificados no gene KISS1R em pacientes com PPC

Tabela 12. Características clínicas da paciente portadora da variante p.H199R no gene LIN28B. 
Tabela 13. Resumo das mutações ou polimorfismos do tipo missense identificados nos genes KISS1R e KISS1 em crianças com PPC

Tabela 14. Análise comparativa da sequência de aminoácidos de LIN28B entre diferentes espécies de mamíferos.

Tabela 15. Resumo das mutações ou polimorfismos identificados no gene LIN28B em crianças com PPC......................................78 


\section{RESUMO}

Silveira-Neto AP. Análise dos genes LIN28B, KISS1 e KISS1R em crianças com puberdade precoce central idiopática [tese]. São Paulo. Faculdade de Medicina, Universidade de São Paulo; 2011. 93p.

A puberdade é um processo biológico complexo do desenvolvimento sexual que tem início no final da infância e se caracteriza pela maturação do eixo hipotálamo-hipófise-gonadal, pelo desenvolvimento dos caracteres sexuais secundários, aceleração do crescimento e finalmente pela capacidade reprodutiva. Nos últimos anos, o peptídeo kisspeptina e seu receptor KISS1R têm sido fortemente envolvidos na regulação da secreção pulsátil do GnRH hipotalâmico e, portanto, com o início da puberdade humana. Mutações nos genes KISS1R e KISS1 foram identificadas em crianças brasileiras com puberdade precoce central (PPC). Estudos em famílias e em irmãs gêmeas estimaram que $50-70 \%$ da variação na idade de menarca pode ser hereditária, porém, até pouco tempo atrás, não se tinha conhecimento de variantes genéticas comuns que influenciassem no tempo de puberdade. Recentemente, quatro estudos independentes de associação ampla do genoma estabeleceram que marcadores genéticos próximos ou dentro do gene $L I N 28 B$ estavam relacionados com a idade da menarca em mulheres normais. Além disso, mutações recessivas no gene lin28 levaram ao desenvolvimento precoce no $C$. elegans. Camundongos que superexpressam Lin28a apresentaram um retardo no desenvolvimento sexual. Com base nesses achados, investigamos a presença de variantes conhecidas ou novas nos genes KISS1, KISS1R e LIN28B em um grupo de crianças portadoras de PPC idiopática com o intuito de estabelecermos a prevalência dessas mutações na etiologia do desenvolvimento sexual prematuro em humanos. Cento e sete crianças com PPC (101 meninas e 6 meninos) foram selecionados, incluindo casos esporádicos e familiares. A população controle consistiu de 200 indivíduos adultos com história de desenvolvimento puberal normal em idade apropriada. A região promotora e os três exons do gene KISS1, os cinco exons do gene K1SS1R e os quatro exons do gene LIN28B foram amplificados e submetidos à sequenciamento automático. Uma variante em homozigose no gene KISS1, descrita anteriormente por pesquisadores do nosso laboratório, p.H90D, foi identificada em mais três crianças não relacionadas, portadoras de PPC idiopática. Essa variante está localizada no exon 3 do KISS1, levando a substituição de uma histidina por um ácido aspártico na posição 90 da kisspeptina-1 (p.H90D), correspondendo à região amino-terminal da 
kisspeptina-54 e estava ausente em 200 controles brasileiros. Estudos prévios in vitro com a variante p.H90D não revelaram alterações na capacidade de ligação ou ativação do KISS1R e na resistência a degradação. As mutações ativadoras p.R386P do KISS1R e p.P74S da kisspeptina, previamente descritas em puberdade precoce central, não foram identificadas no estudo atual. Uma nova e rara variante em heterozigose no gene LIN28B, p.H199R, foi identificada em uma menina brasileira com PPC idiopática. Essa variante está localizada no exon 4 do LIN28B, levando a substituição de uma histidina conservada por uma arginina na posição 199 da proteína (p.H199R) e estava ausente em 200 controles brasileiros. O pai da paciente, que apresentou desenvolvimento puberal normal, era portador da mesma variante em heterozigose. Estudos in vitro revelaram que a variante p.H199R não afeta a função de LIN28B na regulação da expressão do miRNA let-7. Outra variante alélica no gene LIN28B foi identificada numa menina com PPC. Essa variante estava localizada no íntron 2 do gene e uma análise computacional demonstrou que ela não altera o sítio de splicing no RNA maduro. Em conclusão, observamos que mutações nos genes KISS1 e KISS1R têm uma baixa prevalência em crianças com puberdade precoce central idiopática. Descrevemos uma nova e rara variante no gene LIN28B (p.H199R) numa menina com puberdade precoce central e os estudos funcionais do LIN28B selvagem ou contendo a variante p.H199R sugeriram que essa variante não está relacionada ao fenótipo de puberdade precoce.

Descritores: 1.Puberdade precoce 2.Hormônio liberador de gonadotropina 3.Gonadotropinas 4.Sistema hipotálamo-hipofisário 5.Receptor KISS1R 6.LIN28B 


\section{SUMMARY}

Silveira-Neto AP. LIN28B, KISS1 and KISS1R genes analysis in children with idiophatic central precocious puberty [thesis]. São Paulo. "Faculdade de Medicina, Universidade de São Paulo"; 2011. 93p.

Puberty is a complex biological process of sexual development that begins in the late childhood and it is characterized by the maturation of the hipothalamic-pituitary-gonadal axis, secondary sexual characteristics development, growth acceleration and acquisition of the reproductive capacity. Over the last years, the kisspeptin peptide and its receptor KISS1R have been envolved in the regulation of the pulsatile hipothalamic $\mathrm{GnRH}$ secretion and consequently with the beginning of the puberty human. Researchers from our laboratory identified mutations in the KISS1R and KISS1 genes in Brazilian children with central precocious puberty (CPP). Studies performed in families and twins estimated that $50 \%-70 \%$ of the variation in the menarce age can be hereditary, however, until last years, we did not have knowledgment of the influence of commun genetic variants in the puberty time. Recently, four independent Genome-Wide Association Studies established that genetic markers near or inside of LIN28B gene were related with the menarce age in normal women. Furthermore, recessive mutations in the LIN28B gene caused a precocious develpment in $C$. elegans. Interestingly, mouse that overexpress Lin28a exhibited a sexual development delay. Accordingly with these datas investigated the presence of known or new variants in the KISS1, KISS1R and LIN28B genes in a larger cohort of children with CPP to establish the prevalence of these mutations in the etiology of premature sexual development in humans. 107 children with CPP (101 girls and 6 boys) were selected, including sporadic and familial cases. The control population consisted of 200 adults with normal pubertal development. The promoter region and the three exons of $K I S S 1$ gene, five exons of KISS1R and four exons of LIN28B were amplified and automatically sequenced. A homozygous variant previously described by researchers from our laboratory in the KISS1 gene, p.H90D, was identified in more 3 no related children with CPP idiophatic. This variant is located in exon 3 of KISS1, resulting in substitution of a histidine to an aspartic acid at position 90 of kisspeptin-1 (p.H90D), in the amino-terminal region of the protein-54 and was absent in 200 Brazilian controls. Previous studies in vitro with the p.H90D variant did not show alterations in the binding or activation capacity and in the resistance to degradation. The activating mutations p.R386P of the KISS1R and p.P74S of the kisspeptin, previously described in 
central precocious puberty, were not identified in the present study. A new and rare heterozygous variant in the LIN28B gene, p.H199R, was identified in a Brazilian girl with CPP idiophatic. This variant is located in exon 4 of the LIN28B, resulting in substitution of a histidine to an arginine at position 199 of protein (p.H199R) and was absent in 200 Brazilian controls. Her father, which had normal pubertal development, carried the same heterozygous variant.

Studies in vitro revealed p.H199R did not affect the function of Lin28B in the regulation of let-7 miRNA expression. Another allelic variant in the LIN28B gene was identified in a girl with CPP. This variant was located in intron 2 of the gene and an in silico analysis showed that it does not change the splicing site in mature RNA. In conclusion, we observed that mutations in the KISS1 and KISS1R genes have a low prevalence in children with idiopathic central precocious puberty. We described a new and rare variant in LIN28B gene (p.H199R) in a girl with central precocious puberty and functional studies of the wild LIN28B or containing p.H199R variant suggested that p.H199R variant of the LIN28B is not related to the precocious puberty phenotype.

Descriptors: 1.Puberty, precocious 2.Gonadotropin-realising hormone 3.Gonadotropins 4.Hypotalamo-hipophyseal ystem 5.KISS1R receptor 6.LIN28B 
1 INTRODUÇÃO 


\subsection{Puberdade}

A secreção pulsátil do decapeptídeo hipotalâmico GnRH representa o primeiro passo conhecido do processo de ativação seqüencial do eixo hipotálamo-hipófise-gonadal (HHG) [1]. Na glândula hipofisária, o GnRH se liga ao seu receptor na superfície dos gonadotrófos, estimulando a síntese e secreção das gonadotropinas LH e FSH e, conseqüentemente, a secreção dos esteróides sexuais gonadais e a produção de gametas maduros nas gônadas [2]. Os princípios da secreção pulsátil do GnRH, assim como o seu papel fundamental no início da puberdade, foram bem estabelecidos nas últimas duas décadas [3]. Em humanos, o eixo HHG esta ativo durante o período neonatal, seguido por um período de relativa quiescência durante toda a infância. A reemergência da secreção pulsátil de GnRH ocorre no final da infância, marcando o início da puberdade (Figura 1) [1]. Esse complexo processo biológico de desenvolvimento sexual caracteriza-se pela maturação do eixo gonadotrófico, desenvolvimento de caracteres sexuais secundários, aceleração do crescimento e maturação das gônadas (ovários e testículos), com conseqüente aquisição da função reprodutiva [4-6]. No entanto, os mecanismos de inibição do eixo gonadotrófico na infância e de reativação no início da puberdade ainda não foram bem estabelecidos [3]. Fisiologicamente, a idade de início da puberdade varia amplamente e segue 
uma distribuição normal ou Gaussiana [1]. Tal variabilidade é determinada pela interação de um conjunto complexo de fatores, envolvendo aspectos genéticos, étnicos, nutricionais, ambientais e socioeconômicos [1]. Fatores genéticos desempenham uma função importante na idade de início da puberdade. A idade de menarca semelhante entre mães e filhas, e a concordância do desenvolvimento puberal entre gêmeos monozigóticos quando comparados à dizigóticos são fatores que reforçam a influência genética [1]. Atualmente, a hipótese mais aceita para explicar o mecanismo de início do processo puberal envolve a modulação central da secreção de GnRH independente da inibição exercida pelos esteróides gonadais [1, 6, 7]. A regulação da secreção de $\mathrm{GnRH}$ é dependente de uma rede de neuropeptídeos que controlam a secreção pulsátil do $\mathrm{GnRH}$, com fatores inibitórios predominando no período da infância e fatores excitatórios e permissivos desencadeando a reemergência da secreção pulsátil de GnRH no início da puberdade (Figura 1) [1, 6, 7].

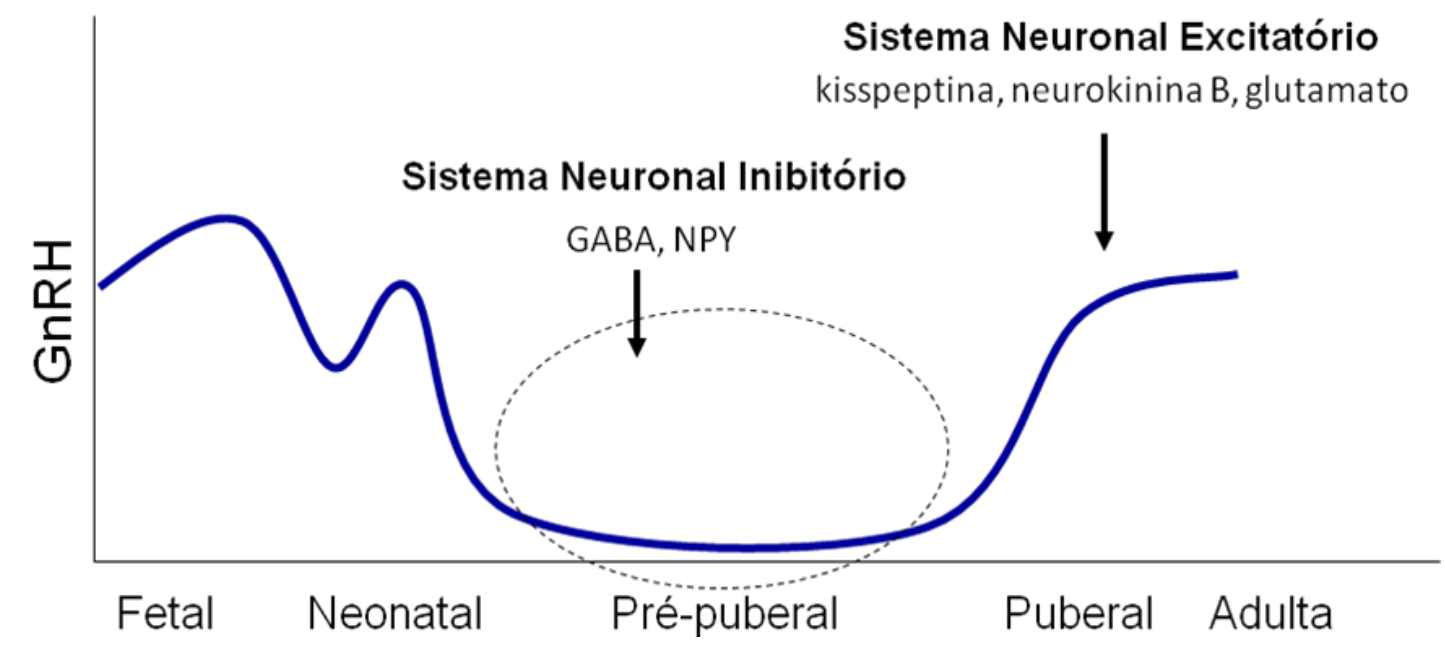

Figura 1. Representação esquemática da secreção de GnRH ao longo da vida 
Vários neurotransmissores e neuromoduladores apresentam propriedades excitatórias ou inibitórias sobre a secreção de $\mathrm{GnRH}$ em mamíferos $[4,6]$. Os principais neurotransmissores e neuromoduladores inibitórios são os opióides endógenos, o ácido gama-amino butírico (GABA), o peptídeo intestinal vasoativo (VIP), o hormônio liberador de corticotrofina $(\mathrm{CRH})$ e a melatonina [6]. Destacam- se como principais neurotransmissores excitatórios: glutamato, norepinefrina, dopamina, serotonina e mais recentemente a kisspeptina, juntamente com o seu receptor, GPR54 ou KISS1R $[6,8]$. Ao neuropeptídeo $\mathrm{Y}$ (NPY) é atribuído tanto uma atividade excitatória quanto inibitória sobre a secreção de GnRH [9]. As células da glia e os fatores de crescimento, tais como fator de crescimento de fibroblastos (TGF $\alpha$ e $\beta$ ), fator de crescimento epidermal (EGF), citoquinas e interleucinas (IL-1 e IL-6), estão também implicados no complexo mecanismo regulatório da secreção de GnRH [4, 7]. O estado nutricional e aquisição de uma massa corporal mínima são importantes para o início do desenvolvimento puberal e ocorrência da menarca. A leptina, hormônio secretado principalmente pelos adipócitos, tem sido implicada no início da puberdade humana [4]. A leptina exerce seu efeito diminuindo a sinalização dos neurônios secretores de NPY e é atualmente considerado um fator permissivo que informa o cérebro sobre os estoques periféricos de energia [7]. 


\subsection{Puberdade precoce central (PPC)}

A puberdade precoce é definida como o desenvolvimento de caracteres sexuais secundários antes dos oito anos de idade nas meninas e dos nove anos nos meninos [10]. Denomina-se puberdade precoce central (PPC), ou dependente de gonadotropinas, quando o desenvolvimento dos caracteres sexuais secundários é conseqüência da ativação prematura do eixo HHG [11].

Clinicamente, é caracterizada pelo desenvolvimento precoce dos caracteres sexuais secundários, aceleração do crescimento linear e avanço da idade óssea, com conseqüente prejuízo da estatura final [11]. A prevalência estimada da PPC é de 1:10.000-1:5.000 [12, 13]. A PPC é considerada idiopática quando o exame de imagem do sistema nervoso central (SNC), preferencialmente a ressonância magnética (RM), afasta causas orgânicas de ativação do eixo gonadotrófico [13]. A PPC idiopática é aproximadamente 10 vezes mais comum em meninas do que em meninos [13]. No sexo masculino, as anormalidades neurológicas são responsáveis por cerca de dois terços dos casos, sendo que os tumores do SNC, principalmente o hamartoma hipotalâmico, representam o fator etiológico de metade dos meninos com PPC [14].

Em 2004 de Vries et al. [15] estudaram retrospectivamente um grande número de crianças israelenses com puberdade precoce. De 453 pacientes estudados, 156 apresentavam a forma de puberdade precoce central. Destas, 147 eram do sexo feminino e nove do sexo masculino. Quarenta e 
três crianças (27\%) apresentavam puberdade precoce familial. Após análise de segregação dessas famílias, foi possível estabelecer um padrão de herança autossômico dominante com penetrância incompleta e sexodependente. Portanto, fatores genéticos parecem ter um papel importante no início da puberdade, mesmo em condições patológicas.

\subsection{Kisspeptinas e seu receptor KISS1R}

\subsubsection{Estrutura gênica e protéical via de sinalização intracelular}

As kisspeptinas são inseridas numa família de neuropeptídeos codificados pelo gene KISS1. O produto inicial desse gene é um peptídeo hidrofílico de 145 aminoácidos, a kisspeptina-1, que apresenta um sítio de processamento de peptídeo sinal, dois sítios dibásicos potenciais de processamento e sítio preditivo de clivagem terminal e amidação [16]. O processamento da kisspeptina-1 origina um peptídeo de 54 aminoácidos denominado kisspeptina-54 [16-18]. A kisspeptina-54 também é conhecida como metastina, devido a sua capacidade de inibir metástases de melanomas e carcinomas de mama humanos $[19,20]$. Outros peptídeos de menor tamanho, como as kisspeptinas -10, -13 e -14 foram também descritos, entretanto, nenhum sítio de clivagem para a síntese endógena desses peptídeos foi detectado, sugerindo que esses peptídeos menores sejam produtos da degradação da kisspeptina-54 [16, 17] (Figura 2). Todos 
esses peptídeos compartilham uma seqüência carboxi-terminal de dez aminoácidos, kisspeptina-10 (112-121 aa), conservada entre as diferentes espécies de mamíferos e vertebrados não mamíferos, e possuem igual afinidade pelo receptor KISS1R [16, 18, 21-23], indicando um importante papel de atuação numa grande variedade de vertebrados. Assim como outros membros da família de neuropeptídeos RF amidas, possuem os aminoácidos arginina e fenilalanina ligada a um grupo amida na região carboxi-terminal [16-18, 24].

\section{Cromossomo $1 \mathrm{q} 32$}

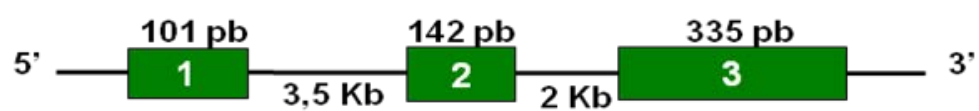

\section{Kisspeptinas}

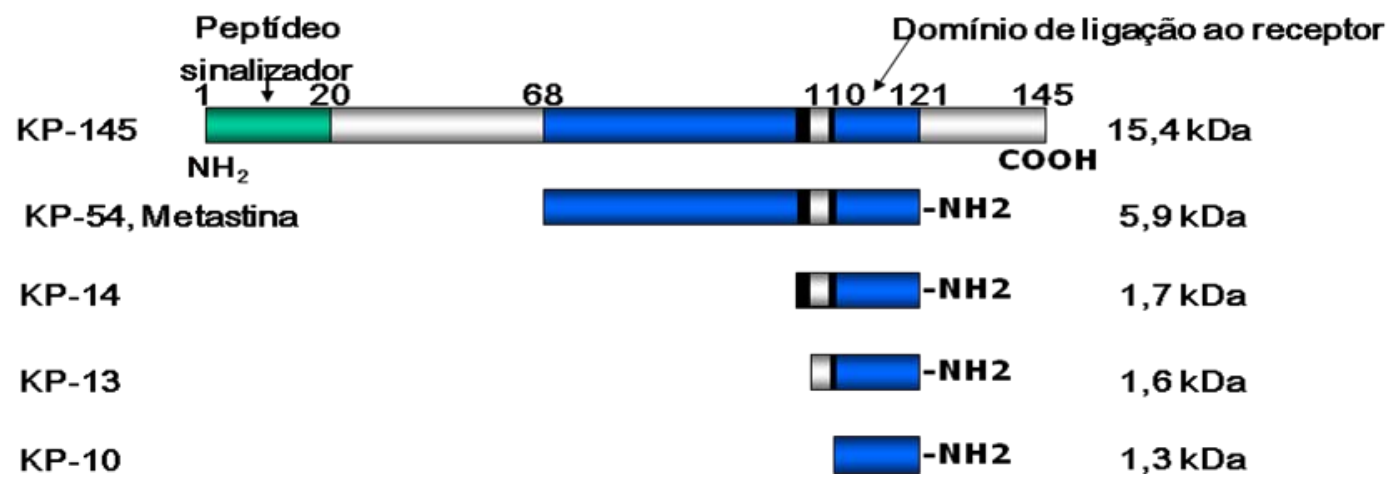

pb, pares de base; Kb, kilobases; KP, kisspeptina; KDa, kilodalton

Figura 2. Representação esquemática do gene KISS1, contendo três exons, e seus produtos protéicos, as kisspeptinas. O RNAm do KISS1 é traduzido em um peptídeo precursor de 145 aminoácidos, chamado kisspeptina-1, que é posteriormente clivada dando origem à kisspeptina-54, também conhecida como metastina. Peptídeos menores, de 14, 13 e 10 aminoácidos também foram identificados. Todos esses peptídeos apresentam um radical RF-amida na porção carboxi-terminal, essencial para a ligação das kisspeptinas ao receptor 
Kotani et al. [16] demonstraram que a kisspeptina-10 (112-121 aa) é responsável pela bioatividade das kisspeptinas, mantendo a mesma eficácia na ativação do KISS1R que os peptídeos maiores. A ausência de um dos 10 resíduos ou da amidação na região carboxi-terminal reduz significativamente a afinidade pelo KISS1R, indicando que essa região é de fundamental importância para a ligação ao receptor [16, 18]. A região amino-terminal da kisspeptina-54 pode estar envolvida em outros processos biológicos, tais como estabilização e proteção contra digestão proteolítica [18].

O gene KISS1 foi descoberto por um grupo de pesquisadores da Universidade da Pensilvânia, na cidade de Hershey, EUA, e foi denominado como KISS1 em homenagem ao famoso chocolate produzido nessa cidade (Hershey's Kisses) [19]. A expressão de KISS1 foi inicialmente identificada em células cancerígenas não metastáticas, levando à descoberta de que o KISS1 poderia suprimir o potencial metastático de linhagens celulares de melanoma e de carcinoma de mama humano $[19,20,25]$. O gene KISS1 humano, localizado no braço longo do cromossomo 1 (1q32) é composto por três exons, sendo que o primeiro exon e os primeiros 38 pb do segundo exon não são traduzidos (Figura 2). A sequência codificadora consiste dos últimos 103 pb do exon 2 e dos primeiros 314 pb do exon 3 [19, 25].

Os transcritos do gene KISS1 são altamente expressos na placenta e em menor grau no cérebro, incluindo o hipotálamo, hipófise, gônadas, fígado, pâncreas e intestino delgado [16-18]. Em 2001, pesquisadores demonstraram que a kisspeptina era o ligante do GPR54, descrito inicialmente como um receptor órfão [26]. O GPR54, atualmente conhecido 
como KISS1R, é um receptor acoplado à proteína G, com 40\% de homologia com receptores da família da galanina [26]. O gene KISS1R humano está localizado na porção telomérica do braço curto do cromossomo 19 (19p13.3) e possui cinco exons [27]. Os primeiros 161 pb do exon 1 não são traduzidos, enquanto os exons 2, 3 e 4 e dos primeiros 359 pb do exon cinco sofrem tradução [17]. Os transcritos do gene KISS1R são altamente expressos na placenta, hipófise e pâncreas e moderadamente expressos nas gônadas, no intestino delgado, nos rins e no cérebro, incluindo o hipotálamo [16-18]. A proteína codificada pelo KISS1R em humanos possui 398 aminoácidos e, como todos os receptores acoplados a proteína G, apresenta sete alfa hélices transmembrana, com um domínio amino-terminal extracelular e um domínio carboxi-terminal intracelular [17].

A ligação da kisspeptina ao seu receptor estimula a ação da fosfolipase C (PLC), por meio da ativação da proteína $G q$, que efetua a hidrólise de fosfatidilinositol $(4,5)$ difosfato $\left(\mathrm{PIP}_{2}\right)$ em diacilglicerol (DAG) e inositol $(1,4,5)$ trifosfato $\left(\mathrm{IP}_{3}\right)$, os quais atuam como segundos mensageiros (Figura 3) [16]. O $\mathrm{IP}_{3}$ é um mediador hidrossolúvel que é liberado no citosol e age por meio do receptor $\mathrm{IP}_{3}$, um canal de cálcio controlado por ligante presente na membrana do retículo plasmático, estimulando a liberação de $\mathrm{Ca}^{2+}$ do retículo endoplasmático para o citosol [16-18]. O DAG, uma substância lipofílica presente na membrana celular, ativa uma proteína quinase ligada à membrana, proteína quinase $C(P K C)$, que catalisa a fosforilação de várias proteínas intracelulares [28]. 


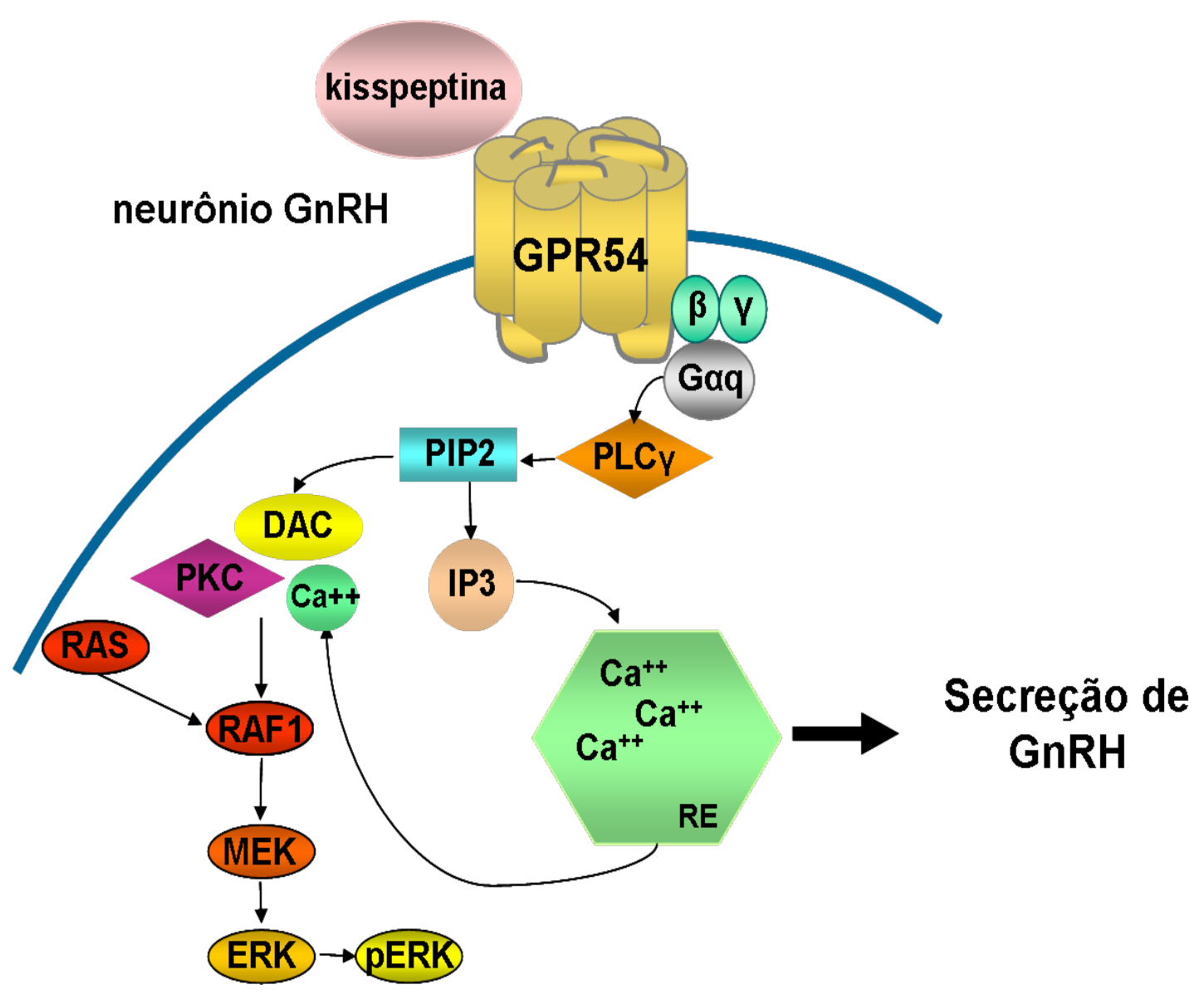

PLC, fosfolipase C; PIP2, fosfatidilinositol $(4,5)$ bifosfato; IP3, inositol $(1,4,5)$ trifosfato; $\mathrm{Ca}^{++}$, cálcio; DAG, diacilglicerol; PKC, proteína quinase C; RAF1, MEK, quinases serinatreonina; ERK, quinase regulada por sinal extracelular; $p E R K, E R K$ fosforilada

Figura 3. Cascata de sinalização da kisspeptina. A ligação da kisspeptina ao receptor acoplado a proteína Gq, GPR54, ativa a PLC, que induz à hidrólise de PIP2 em IP3 e DAG, levando a mobilização de cálcio intracelular e ativação da PKC, que por sua vez leva a fosforilação da ERK

A primeira evidência que as kisspeptinas ativam o receptor KISS1R originou-se da descrição que o extrato placentário humano poderia aumentar a concentração de cálcio intracelular em células $\mathrm{CHO}$ (Chinese hamster ovary) que expressam KISS1R humano ou de rato $[16,18]$. Posteriormente, kisspeptinas isoladas da placenta humana foram capazes de ativar KISS1R humano e murino tranfectados em células CHO-K1 [16]. Castellano et al. 
[29] observaram que o bloqueio de PLC ou a redução de cálcio intracelular das suas reservas intracelulares por bloqueadores específicos resultou na abolição completa da secreção de $\mathrm{GnRH}$ mediada por kisspeptina em tecidos hipotalâmicos cultivados ex vivo, estabelecendo assim evidências que kisspeptina estimula a secreção de $\mathrm{GnRH}$ pelos neurônios $\mathrm{GnRH}$ hipotalâmicos via ativação de KISS1R. Estudos recentes têm demonstrado a capacidade de KISS1R em ativar cascatas de sinalização envolvendo as proteínas quinases ativadas por mitógenos (MAP) [30].

Estudos de sinalização em células CHO-K1 que expressam KISS1R humano ou de rato demonstraram um aumento da taxa de fosforilação nas MAP quinases ERK1/ERK2 e p38 após ativação do KISS1R pela kisspeptina-10, resultando numa forte inibição da proliferação celular [16]. A ativação de quinases pode não somente estar relacionada com os fenômenos de proliferação e migração celular, mas também com a secreção neuroendócrina [29]. De fato, o bloqueio de ERK1/ERK2 e p38 aboliu completamente a secreção de GnRH induzida por kisspeptina-10 em tecidos hipotalâmicos cultivados ex vivo [29].

\subsubsection{Regulação do eixo gonadotrófico}

Nos últimos anos, o peptídeo kisspeptina e seu receptor KISS1R foram fortemente implicados na regulação do início da puberdade [2, 27, 31, 32]. Em 2003, dois grupos de pesquisa independentes identificaram mutações inativadoras no KISS1R em pacientes portadores de hipogonadismo 
hipogonadotrófico isolado $(\mathrm{HHI})$ com olfato normal $[2,27]$. Na mesma época em que mutações no KISS1R foram sendo identificadas em humanos com $\mathrm{HHI}$, modelos murinos knockout para esse gene foram produzidos e também apresentaram características fenotípicas de $\mathrm{HHI}[2,33]$. Camundongos machos knockout para KISS1R (KISS1R-/-) possuíam testículos pequenos, hipodesenvolvimento dos caracteres sexuais secundários, baixas concentrações de testosterona plasmática, espermatogênese comprometida e redução do comportamento sexual. As fêmeas apresentaram abertura vaginal reduzida, valores baixos de estradiol, ausência de folículos e corpo lúteo nos ovários [2, 33]. Os camundongos de ambos os sexos apresentaram concentrações de LH e FSH baixas, quando comparadas aos camundongos selvagens. Os animais KISSIR-/- demonstraram presença de resposta das gonadotropinas ao $\mathrm{GnRH}$ exógeno, indicando integridade do receptor de GnRH hipofisário [2]. Posteriormente, modelos murinos knockout para o gene KISS1 (KISS1-/-) foram desenvolvidos e também exibiram fenótipo típico de $\mathrm{HHI}[34,35]$, entretanto, um desses estudos observou que camundongos KISS1-/- são menos afetados e apresentaram uma maior variabilidade fenotípica do que camundongos KISS1R-/- [35]. De fato, fêmeas de camundongos KISS1-/- demonstraram dois tipos de fenótipos: 50\% exibiram uma drástica redução no tamanho dos ovários e na abertura vaginal, similar ao das fêmeas KISS1R-/-, enquanto que a outra metade não apresentou uma alteração significativa no tamanho ovariano e na abertura vaginal e também apresentou uma persistência da cornificação vaginal, similar aos das fêmeas selvagens (KISS1+/+). Essa variabilidade fenotípica 
observada em fêmeas KISS1-/- sugere que outros peptídeos desconhecidos possam compensar parcialmente a ausência de kisspeptina [34, 35].

Desde então, vários grupos têm demonstrado que a administração de kisspeptina por diferentes vias (intracerebroventricular (ICV), subcutânea, intraperitoneal e intravenosa) estimula a secreção de gonadotropinas, por um mecanismo dependente de GnRH em diferentes espécies de mamíferos, inclusive em humanos [8, 32, 36-38]. No camundongo macho, a administração ICV da kisspeptina-54 ou da kisspeptina-10 foi capaz de aumentar a secreção de LH e FSH 30 minutos após a injeção, até mesmo em baixas doses [36]. Duas linhas de evidência sugerem que as kisspeptinas aumentam a secreção de gonadotropinas por estimular a secreção de GnRH. A primeira evidência indica que o pré-tratamento com os antagonistas do $\mathrm{GnRH}$, acilina [36] ou cetrorelix [39], previnem a secreção de gonadotropinas induzida pela kisspeptina em roedores. A segunda, que a administração de kisspeptina aumenta a secreção de $\mathrm{GnRH}$, simultaneamente a secreção de LH em ovelhas [37]. A kisspeptina parece estimular a liberação de gonadotropinas atuando somente em seu receptor, uma vez que ela não foi capaz de promover a liberação de gonadotropinas em camundongos KISS1R-/- [37]. A expressão de kisspeptina foi identificada por hibridização in situ e imunohistoquímica principalmente nos núcleos arqueado (ARC) e paraventricular anteroventral (AVPV) do hipotálamo de roedores, com um pequeno grupo de neurônios secretores de kisspeptina também sendo identificados no núcleo periventricular (PeN) [36, 40, 41]. Em camundongos, os neurônios secretores de kisspeptina projetam 
seus axônios para os dendritos e corpos celulares dos neurônios GnRH na área pré- óptica (POA) do hipotálamo [40]. De fato, outros estudos também demonstraram uma co-localização de 70-90\% de neurônios GnRH e kisspeptina em ovelhas e macaco Rhesus, sugerindo que kisspeptina atua diretamente nos neurônios GnRH para regular o eixo HHG $[42,43]$. Estudos de expressão gênica e hibridização in situ revelaram que transcritos do gene KISS1R também são expressos em neurônios GnRH de diferentes espécies, incluindo peixes, macacos e roedores [24].

A sinalização do complexo kisspeptina/KISS1R está envolvida na regulação do início da puberdade nos roedores e primatas. Além das observações que camundongos KISS1R -/- e KISS1 -/- não apresentam uma maturação sexual adequada [2, 33-35], a administração de kisspeptina em roedores e primatas pré-púberes induziu a ativação prematura do eixo gonadotrófico, observado pelo aumento na secreção das gonadotropinas hipofisárias [34, 43]. De fato, a administração ICV de kisspeptina-10 murina a cada 12 horas durante sete dias induziu à abertura vaginal precoce, aumento do peso uterino e aumento das concentrações de LH e estradiol em ratas imaturas [32]. Posteriormente, foi observado que a administração intermitente de kisspeptina-10 foi mais eficiente em manter a secreção de GnRH do que a infusão contínua desse peptídeo em macacos Rhesus machos agonádicos, a qual produziu uma dessensibilização do receptor KISS1R [44].

É provável que a estimulação do KISS1R pela kisspeptina aumente no decorrer da puberdade. De fato, estudos demonstraram que as 
concentrações hipotalâmicas de transcritos dos genes KISS1 e KISS1R aumentam nesse período em roedores [31, 45] e primatas [38]. Em roedores, foi observado um aumento dos transcritos do KISS1 no núcleo AVPV e também um aumento no número de neurônios $\mathrm{GnRH}$ despolarizados pela kisspeptina [31, 40]. Esse aumento no número de neurônios GnRH despolarizados durante a puberdade, parece ser devido a uma maior sensibilidade do KISS1R à kisspeptina e na aposição de neurônios kisspeptina com neurônios $\mathrm{GnRH}$, juntamente com o aumento de transcritos KISS1 no hipotálamo [31].

Atualmente, está bem estabelecido que o eixo HHG é regulado pelos esteróides gonadais. Recentes estudos demonstraram que neurônios kisspeptina expressam receptor de estrógeno alfa (ERa), receptor de prolactina (PR) e receptor de andrógeno (AR), atribuindo assim a esses neurônios a capacidade de mediar as ações de esteróides gonadais na regulação da secreção de $\mathrm{GnRH}$ [46-48]. De fato, a redução na atividade de neurônios secretores de kisspeptina no núcleo ARC de roedores, primatas e ovelhas é responsável por traduzir a retroalimentação positiva empregada pelos esteróides gonadais na secreção de GnRH [49]. A ovariectomia (OVX) em fêmeas e a castração em machos de camundongo [50, 51], ovelha $[42,47]$ e macaco Rhesus $[52,53]$ levaram ao aumento das concentrações de transcritos KISS1 nos neurônios kisspeptina do ARC. A reposição de esteróides sexuais nesses animais induziu uma redução dos transcritos KISS1 para valores normais observados em animais selvagens [42, 47, 51-53]. Entretanto, a kisspeptina não deve ser o único fator atuando na secreção de 
GnRH, uma vez que em camundongos KISS1R -/- ainda foi observado pulsos basais de LH [2]. De maneira interessante, os neurônios kisspeptina co-localizam com os neurônios dinorfina $A$ e neuroquinina $B$, os quais também expressam ER-a, PR e AR. Assim, é possível que todos esses neurônios exerçam uma ação em conjunto para regular a retroalimentação negativa no núcleo ARC de ovelhas [48].

O estrógeno também regula a retroalimentação positiva do eixo HHG através de neurônios secretores de kisspeptina localizados no núcleo AVPV, durante o ciclo estral de fêmeas de roedores [50, 54]. Smith et al. [50] observaram uma redução na expressão de transcritos KISS1 no AVPV de ratas OVX e um aumento desses transcritos após reposição de estrógeno nesses animais. Em ratas selvagens, as concentrações de transcritos de KISS1 no AVPV aumentam no final do pro- estro, período que antecede o pico de LH e a ovulação [54].

Kauffman et al. [41] observaram que a expressão de transcritos KISS1 é 12 vezes mais alta no núcleo AVPV de ratas, sendo esse dimorfismo sexual decorrente da exposição de esteróides sexuais durante a vida prénatal. De fato, ratas expostas à testosterona durante a vida neonatal desenvolvem concentrações ou valores de transcritos KISS1 similares aos de machos no AVPV, em contrapartida, camundongos KISS1R -/- machos desenvolvem concentrações de transcritos KISS1 similares aos de fêmeas, devido às baixas concentrações de testosterona. Esses dados sugerem que a testosterona é um importante fator na diferenciação de neurônios kisspeptina durante a vida neonatal de ratos [41]. 


\subsubsection{Mutações inativadoras no gene KISS1R associadas ao hipogonadismo hipogonadotrófico}

O hipogonadismo hipogonadotrófico isolado $(\mathrm{HHI})$ é causado por um defeito na produção ou secreção de GnRH pelo hipotálamo ou pela resistência hipofisária à ação do $\mathrm{GnRH}$ [55]. Em 2003, dois grupos de pesquisa independentes descobriram que mutações no KISS1R estavam associadas ao desenvolvimento de $\mathrm{HHI}$ em humanos [27, 55]. De Roux et al. [27] identificaram uma deleção de 155 nucleotídeos em homozigose no gene KISS1R de 5 irmãos com HHI, membros de uma família co- sanguínea. Essa deleção removeu o sítio aceptor de splicing da junção íntron 4-exon 5 e parte do exon 5 do gene, levando a perda dos domínios 6 e 7 de localização transmembrana e assim incapacitando a ativação do KISS1R. No mesmo ano, Seminara et al. [2] também observaram mutações nesse gene em pacientes hipogonádicos, uma mutação em homozigose, p.L148S, em seis membros de uma família co-sanguínea e duas mutações em heterozigose, p.R331X e p.X399R, num homem. As células COS-7 transfectadas com plasmídeos contendo as sequências dos três receptores mutantes apresentaram uma redução significante no acúmulo de $\mathrm{IP}_{3}$. As mutações p.R331X e p.X399R levaram a um ganho e perda do stop códon, respectivamente, e a análise de expressão por PCR em tempo real revelou uma redução de seus transcritos.

A descoberta dessas mutações posicionou definitivamente a kisspeptina e KISS1R como importantes reguladores do eixo HHG e da 
puberdade [49]. Desde então, outras mutações no KISS1R têm sido relacionadas com o desenvolvimento de $\mathrm{HHI}$ em humanos. Semple et al. [56] identificaram as mutações p.C223R e p.R297L num menino, as quais induziram a uma redução na capacidade de sinalização, com p.C223R exibindo uma maior redução na liberação de $\mathrm{Ca}^{++}$após estímulo com kisspeptina-10 em células HEK-293. Outro grupo de pesquisadores observou a mutação (1001_1002insC) num homem, resultando num aumento de 43 aminoácidos na sequência da proteína e numa alteração significante da estrutura protéica [57]. Em 2007, 5 pacientes com HHI de duas famílias co-sanguíneas exibiram a mutação p.L102P, que revelou uma redução significante na ativação de KISS1R pela kisspeptina-10 em células HEK-293, provavelmente devido a uma mudança conformacional no receptor [58]. Mais recentemente, pesquisadores do nosso laboratório identificaram uma mutação em homozigose no KISS1R em dois irmãos com HHI [59]. Essa variante foi caracterizada pela deleção de 3 nucleotídeos (GCA) na posição -2 a -4 e uma inserção de sete nucleotídeos (IVS2 -2_-4delGCAinsACCGGCT) no íntron 2 (indel). A análise in silico para predição de sítio de splicing confirmou que essa variante poderia gerar uma proteína anormal, devido à perda do sítio constitutivo de splicing e uso de sítios crípiticos [59].

No entanto, apenas 2\% dos casos de HHI estão relacionados com mutações no gene KISS1R [49]. 


\subsubsection{Mutações ativadoras nos genes KISS1R e KISS1 associadas à puberdade precoce central}

Até pouco tempo atrás, não se tinha conhecimento sobre alterações estruturais em genes que afetassem o eixo gonadotrófico causando puberdade precoce central (PPC). Recentemente, pesquisadores do nosso laboratório [60, 61] encontraram mutações nos genes KISS1R e KISS1, respectivamente, em crianças com PPC idiopática. Teles et al. [60] realizaram estudos de amplificação e sequenciamento do KISS1R a partir do DNA genômico de 53 crianças com PPC. O sequenciamento automático do DNA genômico de uma das meninas analisadas revelou uma substituição em heterozigose de guanina por citosina no nucleotídeo c.1157 presente no exon 5 do gene $K I S S 1 R$, resultando na substituição de arginina por prolina no códon 386 (p.R386P) na região carboxi-terminal do receptor. Estudos in vitro realizados em células COS-7 transfectadas com o tipo selvagem ou mutante (p.R386P) do receptor revelaram que a velocidade de declíneo do acúmulo de fosfato inositol foi mais lenta em células transfectadas com p.R386P do que em células transfectadas com o tipo selvagem do receptor, após estimulação com kisspeptina. De maneira semelhante, a fosforilação da ERK se apresentou prolongada no KISS1R mutante, confirmando assim um ganho de função da via de sinalização intracelular em resposta a kisspeptina. Esses achados sugeriram uma redução significante no índice de dessensibilização do KISS1R mutante. Complementando esses achados, estudos cinéticos de ligação ao receptor sugeriram uma redução no índice de internalização ou degradação da mutação p.R386P do KISS1R quando comparado ao tipo 
selvagem. Esse modelo de ativação não constitutiva do receptor que é caracterizado por uma redução em seu índice de dessensibilização, pode aumentar os efeitos estimulantes da kisspeptina na secreção de GnRH e, consequentemente acelerar a maturação do eixo reprodutivo nessa menina.

Silveira et al. [61] estudaram o gene KISS1 em 83 crianças com PPC idiopática. O sequenciamento automático do DNA de um menino com PPC revelou uma transição em heterozigose de citosina por timina no nucleotídeo c.369 presente no exon 3 do gene KISS1, resultando na substituição de prolina por serina no aminoácido 74 (p.P74S) (58) (Figura 4). Esse aminoácido é conservado em diferentes espécies de mamíferos e está localizado em uma sequência PEST, uma região rica nos aminoácidos prolina $(P)$, ácido glutâmico $(E)$, serina $(S)$ e treonina $(T)$, associada com proteínas de rápida degradação (Figura 4) [62, 63].

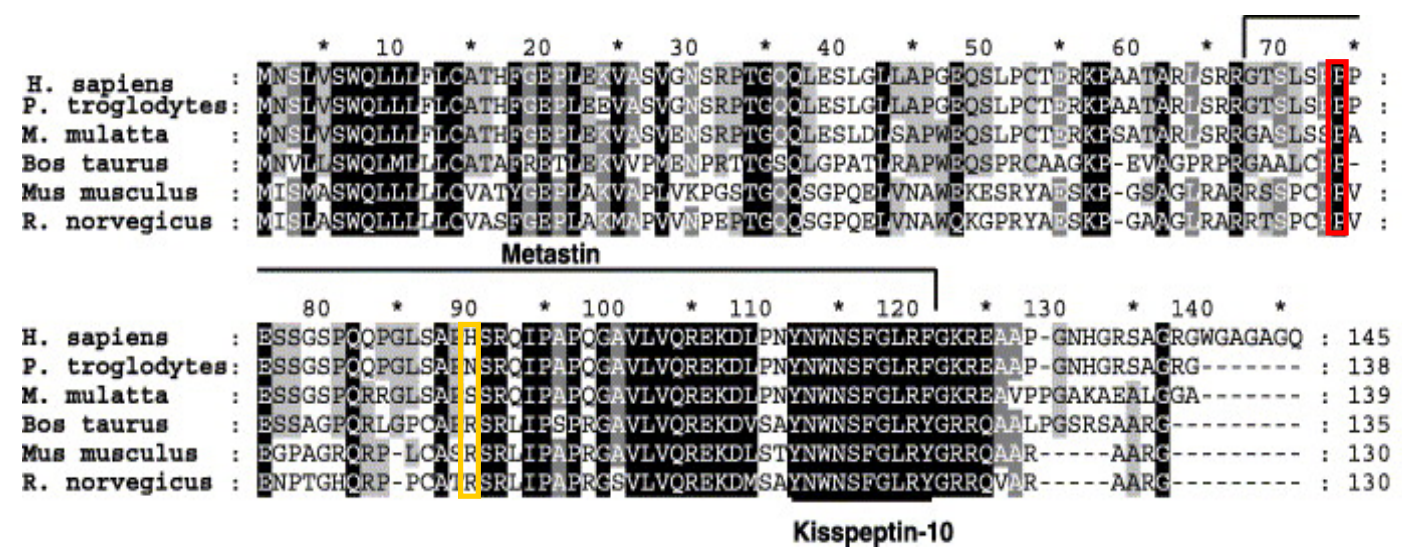

Figura 4. Alinhamento da sequência de amino ácidos da kisspeptina de diferentes espécies de mamíferos. As fontes das sequências são: Homo sapiens (GenBank, NP_002247.2), Pan troglodytes (GenBank, XP_514123.1), Macaca mulatta (GenBank, XP_001098284.1), Bos taurus (GenBank, XP_872566.1), Rattus norvegicus (GenBank, NP_859043.1) e Mus musculus (GenBank, NP_839991.1). A prolina na posição 74, substituída na variante p.P74S, está destacada em vermelho e a histidina na posição 90 , substituída na variante p.H90D, está destacada e em amarelo. Adaptado de Roa et al. [64] 
A incubação das kisspeptinas selvagem (kp54-wt) e mutante (kp54P74S) em soro humano a 50\%, por um período de duas horas, revelou que a taxa de degradação da kp54-P74S é menor do que kp54-wt [61]. A mãe e avó materna do paciente portador da mutação P74S apresentaram a mesma variante, entretanto, elas não apresentavam um histórico de puberdade precoce. De acordo com descrições anteriores [15], esses achados sugerem uma penetrância incompleta ou um fenótipo sexo dependente. Esses dados em conjunto sugerem que a mutação p.P74S possui uma maior resistência a degradação in vitro, podendo levar ao aumento na disponibilidade de kisspeptina e consequentemente influenciar o desenvolvimento do fenótipo de puberdade precoce nesse menino. Uma segunda variante, c.422 C>G, foi identificada em homozigose em uma menina com PPC [61]. Essa variante também está localizada no exon 3, levando à substituição de uma histidina não conservada por um ácido aspártico na posição 90 da kisspeptina (p.H90D) (Figura 4). A mãe da paciente, com histórico de menarca aos 10 anos de idade, era portadora da mesma variante em heterozigose. O pai da paciente não estava disponível para avaliação. Estudos in vitro com a variante p.H90D não revelaram alterações na capacidade de ligação ou ativação do KISS1R e na resistência a degradação [61]. 


\subsection{LIN28}

\subsubsection{Lin28B e puberdade}

Estudos em famílias e em irmãs gêmeas estimaram que 50-70\% da variação na idade de menarca pode ser hereditária, porém até pouco tempo atrás não se tinha conhecimento de variantes genéticas comuns que influenciassem o tempo da puberdade [65]. Recentemente, quatro estudos independentes de associação ampla do genoma (genome-wide association studies, GWAS) estabeleceram que marcadores genéticos próximos ou dentro do gene $L I N 28 B$ estavam relacionados com a idade da menarca em mulheres normais [65-68].

He et al. [66] realizaram uma análise combinada de dois estudos de associação (GWAS) para idade de menarca num total de 17.438 mulheres e observaram que seis polimorfismos de nucleotídeo único (SNPS) no LIN28B (quatro na região 5' upstream e dois no íntron 2) estavam associados com a idade da menarca. Ong et al. [67] conduziram outro estudo de associação para idade de menarca em 4.714 mulheres provenientes de dois estudos populacionais gerais e um estudo de obesidade. Este estudo revelou que somente um SNP no íntron 2 (rs314276) do gene LIN28B alcançou significância estatística $\left(p=1,5 \times 10^{-8}\right.$ ) e que cada cópia do alelo $\mathrm{C}$ estava associada com idade média de menarca 0,22 anos mais cedo. Uma metaanálise de estudos multicêntricos de replicação em 16.373 mulheres associou cada alelo C com idade de menarca 0,12 anos mais cedo [67]. 
Ong et al. [67] posteriormente genotiparam o SNP rs314276 no íntron 2 do gene LIN28B em estudos envolvendo população pediátrica e adulta com o intuito de explorar sua associação com o tempo de início da puberdade. Essa genotipagem revelou que o alelo C comum estava associado com desenvolvimento mais precoce das mamas em meninas, de pêlos pubianos e mudança de voz em meninos e maior velocidade de crescimento em ambos os sexos.

Perry et al. [68] realizaram uma meta-análise de oito diferentes estudos de associação do genoma (GWAS) para idade de menarca em 17.510 mulheres. Esses estudos mostraram que dez SNPs apresentaram significância estatística $\left(p<5 \times 10^{-8}\right)$ e que eles estavam presentes no cromossomo 6q21, mais especificamente no gene LIN28B. Cada cópia do alelo T do SNP rs7759938 que apresentou maior significância $\left(p=7,0 \times 10^{-9}\right)$ foi associado com redução da idade de menarca em aproximadamente cinco semanas.

Finalmente, Sulem et al. [65] realizaram também um estudo de associação do genoma (GWAS) para idade de menarca em 15.297 mulheres de um estudo populacional e observaram que cinco SNPs no cromossomo 6 q21 se mostraram significantes $\left(p<1,6 \times 10^{-7}\right)$. Na tentativa de replicar esta associação, foi realizada apenas a genotipagem do SNP rs314280, localizado na região 5' do gene LIN28B, num grupo adicional de 7.212 mulheres e uma replicação dessa associação em cada um dos grupos estudados foi constatada. Posteriormente uma estimativa combinada dos efeitos do polimorfismo rs314280 na idade de menarca nas amostras do 
primeiro estudo e do estudo de replicação demonstrou que cada cópia do alelo T desse SNP estava associada com ocorrência de menarca, 1,2 meses mais tarde. Eles também observaram a formação de dois haplótipos a partir dos SNPs rs314280 e rs314277 intrônico (rs314280[T], rs314277[A]; rs314280[T], rs314277[C]) que foram associados com idade em menarca. A estimativa combinada do efeito dos haplótipos rs314280[T], rs314277[C] e rs314280[T], rs314277[A] foram 0,9 meses e 1,9 meses mais tardia idade de menarca, respectivamente [65].

Os quatro diferentes artigos mencionados anteriormente, observaram que a maioria dos SNPs que alcançaram significância estatística no estudo de associação e que foram relacionados com idade de menarca estavam presentes numa região de alto desequilíbrio de ligação no cromossomo 6q21, a qual mostrou sobreposição com o gene LIN28B. Além disso, é provável que os SNPs detectados nesses estudos não estejam no loci causal, entretanto, eles estão em alto desequilíbrio de ligação com as variantes que podem ter as maiores associações com a variação na idade de menarca [65-68].

\subsubsection{Estrutura gênica e protéica}

O gene heterocrônico lin28 foi originalmente identificado como um regulador do tempo de desenvolvimento no nematóide Caenorhabditis elegans [69]. Os vertebrados possuem dois tipos de Lin28: Lin28a (também conhecido como Lin28) e Lin28b [70]. Em humanos, os transcritos do gene 
LIN28A (1p26) são expressos em células-tronco embrionárias e em células de carcinoma embrionário indiferenciado $[71,72]$. O gene LIN28B (6q21), composto por quatro exons, é expresso em testículos, placenta, fígado fetal e linhagens celulares indiferenciadas de carcinomas [70]. As proteínas codificadas pelos genes LIN28A e LIN28B apresentam 209 e 250 aminoácidos, respectivamente, e possuem dois domínios conservados que contêm sequências padrão para ligação ao RNA, sendo eles: um domínio de choque frio (CSD) amino terminal e dois dedos de zinco do tipo $\mathrm{CCHC}$ retroviral (ZFD) carboxi-terminal $[70,73]$. O domínio de choque frio é assim denominado por compartilhar as sequências características da família de proteínas de choque frio bacterianas [73]. Em nematóides e mamíferos, a proteína LIN28 localiza-se principalmente no citoplasma, entretanto, em cerca de $2 \%$ das células, pode ser encontrada também no núcleo [70]. Estudos em células Huh7 de carcinoma hepatocelular humano sugerem que a distribuição de LIN28B pode ser específica para cada fase do ciclo celular, uma vez que foi observado um acúmulo dessa proteína no núcleo das células nas fases $\mathrm{S}$ e G2 do ciclo celular, na frequência de 60\% e 30\%, respectivamente [70].

\subsubsection{Lin28 regula o tempo de desenvolvimento em Caenorhabditis elegans}

Os genes heterocrônicos compõem uma hierarquia genética regulatória que controla o tempo de desenvolvimento em larvas de $C$. elegans [69]. Mutações nesses genes podem causar a omissão (precocidade) 
ou reiteração (retardo) de eventos específicos de um estágio particular do desenvolvimento pós-embrionário, sugerindo que a expressão e atuação desses genes é estágio-específica [74].

Uma variedade de eventos do desenvolvimento é afetada por mutações em genes heterocrônicos, incluindo modelos de divisão celular, duração de ciclos celulares e eventos de diferenciação estágio-específico terminal $[69,75,76]$. Mutações recessivas no gene lin28 em C. elegans levam à alteração no tempo de expressão de eventos específicos para o desenvolvimento em vários tecidos, resultando em desenvolvimento precoce [69]. Nesses casos, eventos específicos do desenvolvimento para o segundo estágio larval (L2) são alterados e assim eventos que ocorreriam normalmente mais tardiamente, ocorrem num estágio mais cedo do que o normal [69]. Por exemplo, C. elegans com mutações recessivas nesse gene apresentam um modelo de divisão celular das células de junção da hipoderme lateral característico da terceira fase larval (L3) uma etapa antes do normal, na fase larval L2 e consequentemente todos os demais eventos tardios, incluindo a síntese de cutícula adulta, ocorrem precocemente [69]. Outros eventos de desenvolvimento, tais como a diferenciação e a divisão celular que são responsáveis pela formação da vulva hemafrodita, também são afetados nesses animais, resultando na deformação do órgão reprodutor e incapacidade de desova [76]. 


\subsubsection{LIN28 e sua associação com miRNAs}

Micro RNAs (miRNA) são moléculas de RNA fita simples de 19-25 nucleotídeos, não codificadores de proteínas, que agem como potentes reguladores pós-transcricionais da expressão gênica em plantas e animais. Os miRNAs exercem seus efeitos regulatórios ligando-se à região 3' não traduzida de RNAs mensageiros (RNAm). Este mecanismo de atuação permite a redução dos valores protéicos de seus genes-alvo, raramente afetando o grau de expressão transcricional. A biogênese do miRNA se inicia com a transcrição de seu gene pela RNA polimerase II, gerando um longo transcrito de miRNA primário (pri-miRNA) contendo cap 5' e cauda poli(A). O pri-miRNA apresenta uma estrutura hairpin ou grampo de cabelo em seu arcabouço que é clivada ainda no núcleo pela enzima RNase III Drosha e seu cofator DGCR8 (DiGeorge syndrome critical region gene 8), gerando uma molécula precursora do miRNA maduro denominada prémiRNA, com cerca de 70 nucleotídeos. Em seguida, o pré-miRNA é transportado ao citoplasma, onde é processado pela RNase III Dicer, gerando um miRNA de fita dupla com aproximadamente 22 nucleotídeos. Esse produto é incorporado a um complexo multimérico denominado RISC (RNA-induced silence complex), que inclui as proteínas argonautas como principais componentes. Apenas uma das fitas do duplex de miRNA permanece no complexo RISC para controlar a expressão pós-transcricional de genes-alvo [77] (Figura 5). 


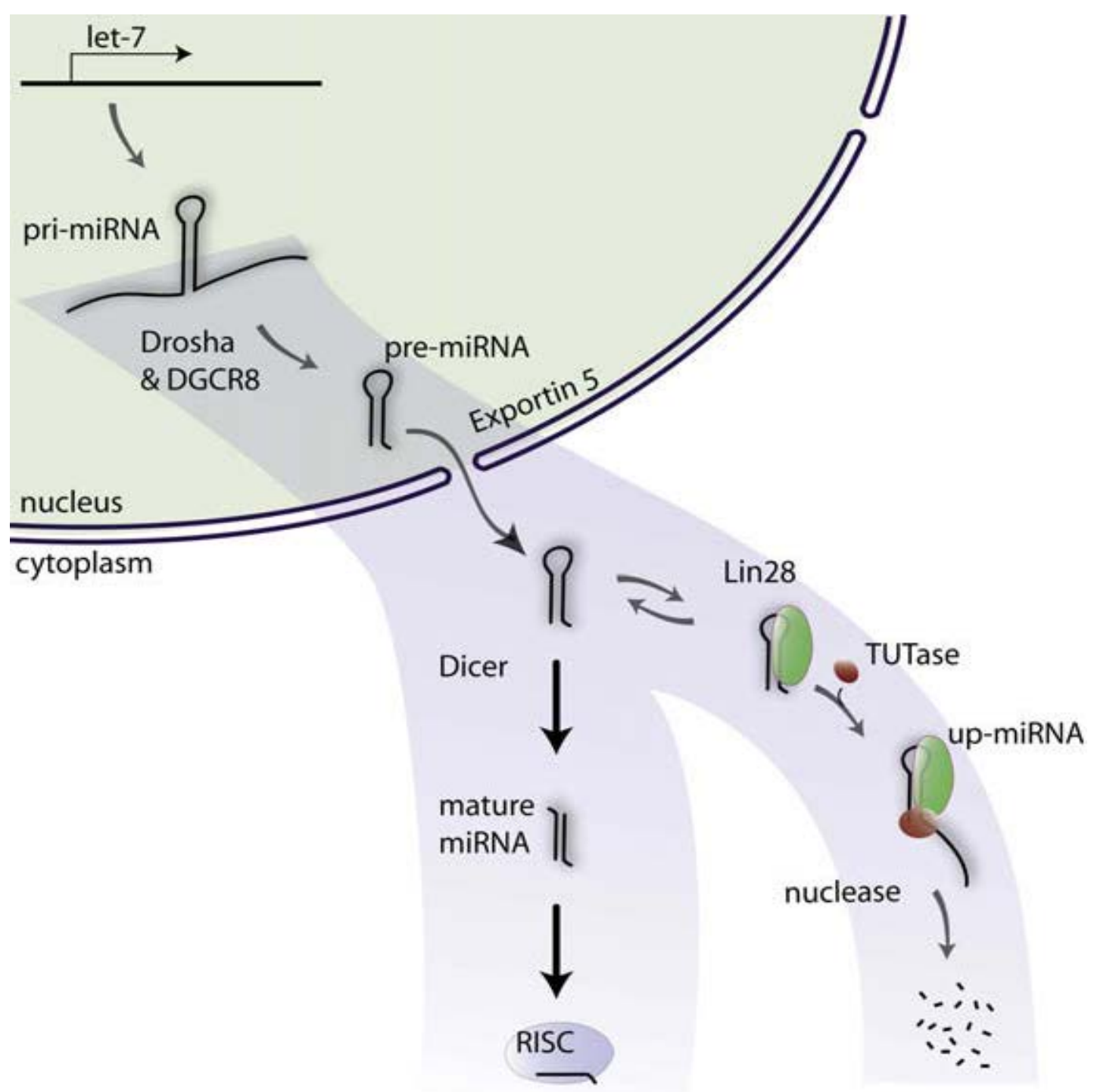

Figura 5. Modelo dos processos de maturação e regulação do microRNA let-7. O transcrito pri-let-7 é processado em pré-miRNA pela enzima Drosha, cuja atividade pode ser afetada pela ligação do Lin28. Após transporte ao citoplasma, o prémiRNA é processado numa forma madura pela enzima Dicer, a qual ação também pode ser afetada pela ligação do Lin28. Entretanto, o caminho de processamento da Dicer é efetivamente divergido com a chegada da enzima TUTase, uma vez que o pré-miRNA é irreversivelmente transformado em pré-miRNA uridilado (upmiRNA), a qual pode ser posteriormente degradado por nucleases. Adaptado de Heo et al. [78] 
O processamento de vários pri-miRNAs é bloqueado em tecidos embrionários, com sua reativação ocorrendo no decorrer do desenvolvimento [78]. Alguns pri-miRNAs são altamente expressos em célulastronco embrionárias murinas e humanas, células de carcinoma embrionário murino e tumores primários humanos, entretanto, os miRNAs maduros não são detectáveis nessas células [79]. Viswanathan et al. [79] observaram que a expressão de Lin28a é regulada negativamente durante a diferenciação de células-tronco embrionárias em roedores e coincide temporalmente com a ativação do processamento do pri-let-7. De fato, sabe-se que proteínas animais com domínio CSD atuam na repressão traducional e estabilização de mRNAs nos primeiros estágios de células embrionárias [80, 81]. A redução de expressão de LIN28B humano em células de carcinoma hepatocelular Huh7 levou ao aumento nas concentrações de miRNA maduro de alguns membros da família let-7, enquanto que as concentrações de pri-let-7 permaneceram inalteradas, sugerindo que LIN28B reprime a biogênese de let-7 sem afetar significantemente o processamento da enzima Drosha [78]. A imunoprecipitação de Lin28a murino expresso ectopicamente em células HEK-293 e posterior análise por Northern blot e PCR em tempo real revelou que pré-let-7 estava fortemente associado ao Lin28a [78]. Estudos in vitro realizados com extratos das células HEK-293 transfectadas com Lin28a e LIN28B demonstraram que tanto o Lin28a quanto o LIN28B induzem a uridilação 3' terminal do pré-miRNA de let-7, fenômeno que evita o processamento desse mRNA pela enzima citoplasmática Dicer e aumenta sua susceptibilidade a degradação [78]. A uridilação 3' terminal no RNA é conhecida por ser um marcador para a 
degradação [82]. Posteriormente foi demonstrado que Lin28a recruta a enzima Zcchc11, uma uridil-transferase (TUTAse), para realizar a uridilação 3' terminal do pré-let-7a e consequentemente bloquear o seu processamento em célulastronco embrionárias [83]. Além disso, a redução de expressão de Zcchc11 e Lin28a aliviou a inibição seletiva do processamento de pré-let-7 e levou ao acúmulo de miRNA maduro de alguns membros da família let-7 em células tronco embrionária de roedores [83].

Os miRNAs da família let-7 são conhecidos por controlarem o tempo de desenvolvimento de $C$. elegans e atuarem como supressores tumorais [84]. Em humanos e camundongos, essa família de miRNAs é composta por doze membros que apresentam uma alta homologia na sequência dos miRNAs maduros [77]. Esses miRNAs regulam negativamente oncongenes tais como k-Ras, c-Myc e HmgA2 e inibem a proliferação e tumorigênese quando expressos ectopicamente em células murinas e humanas [85]. De fato, alguns loci que codificam esses miRNAs estão frequentemente deletados em células cancerígenas humanas [84]. Recentemente, LIN28A foi utilizado juntamente com OCT4, NANOG, e SOX2 para reprogramar pluripotencialidade de fibroblastos somáticos humanos [86].

Uma vez que mutações nos genes KISS1 e KISS1R estão implicadas no desenvolvimento de PPC e polimorfismos no gene LIN28B estão relacionados com o tempo de puberdade em humanos, no presente trabalho pesquisamos a presença de mutações ou polimorfismos nesses genes em pacientes com PPC de origem idiopática e, conseqüentemente, estabelecemos suas prevalências nos pacientes afetados com essa doença. 
2 OBJETIVOS 
2.1- Identificar mutações e polimorfismos nos genes KISS1, KISS1R e LIN28B em pacientes com puberdade precoce central idiopática.

2.2- Correlacionar os achados moleculares com o fenótipo dos pacientes e segregá-los entre os membros da família.

2.3- Determinar a prevalência de conhecidas ou novas mutações e polimorfismos nos genes KISS1, KISS1R e LIN28B em pacientes com puberdade precoce central idiopática.

2.4- Avaliar as consequências funcionais das novas mutações dos genes KISS1, KISS1R e LIN28B eventualmente identificadas. 
3 MÉTODOS 
Este estudo foi aprovado pela Comissão de Ética do Hospital das Clínicas da Faculdade de Medicina da Universidade de São Paulo (HCFMUSP/aprovação $n^{\circ}$ 0892/08) e o consentimento informado formal foi concedido pelos pacientes ou responsáveis.

\subsection{Pacientes}

Crianças com puberdade precoce central idiopática foram selecionadas no ambulatório da Unidade de Endocrinologia do Desenvolvimento do Hospital das Clínicas da Faculdade de Medicina da USP, São Paulo (HCFMUSP), no Centro de Investigações Endocrinológicas do Hospital de Niños Ricardo Gutiérrez, Buenos Aires, além de alguns casos isolados provenientes de outros serviços. Um grupo controle de 200 indivíduos adultos, 133 mulheres e 77 homens, que não apresentaram anormalidades no desenvolvimento puberal foi também selecionado.

Dos 107 pacientes com PPC, 101 (94,4\%) eram do sexo feminino e seis $(5,6 \%)$ do sexo masculino. Teles et al. [60] e Silveira et al. [61] estudaram os genes KISS1R e KISS1 em 53 e 83 pacientes com PPC desta casuística, respectivamente. Estudamos um grupo adicional de 54 pacientes com PPC para o gene KISS1R e 8 pacientes para o gene KISS1. O maior 
número de pacientes estudados para o gene KISS1R se deve ao fato que a grande parte do DNA de pacientes estrangeiros foram encaminhados ao nosso laboratório em pequenas quantidades e exclusivamente para o estudo do gene KISS1R. Os critérios clínicos e laboratoriais considerados para inclusão dos pacientes com PPC no presente estudo foram: início dos caracteres sexuais secundários antes dos 8 anos nas meninas e dos 9 anos nos meninos, concentrações de LH puberais em condição basal e/ou após estímulo com GnRH exógeno, ressonância magnética (RM) do SNC sem anormalidades e resposta terapêutica satisfatória ao tratamento com análogos de GnRH depot. Noventa pacientes dos 107 pacientes apresentavam a forma esporádica e 17 pacientes, pertencentes a 13 famílias, apresentavam a forma familial de PPC, totalizando 15,9\% de casos familiares. A idade cronológica (IC) média do início do aparecimento dos caracteres sexuais secundários foi de 5,1 \pm 2 anos ( $0-7,9$ anos). O estágio de desenvolvimento mamário variou de 2 a 5 e o estádio dos pêlos pubianos variou de 1 a 5, de acordo com os critérios de Tanner e Marshall [87, 88]. Os pacientes do sexo masculino apresentaram diâmetro testicular superior a $2,5 \mathrm{~cm}$ ou volume testicular maior que $4 \mathrm{~mL}$ ao diagnóstico. A idade óssea (IO) média foi $10 \pm 2$ anos (2 - 12,5 anos), segundo os critérios de Greulich e Pyle [89]. Resumimos nas Tabelas 1 e 2 os achados clínicos de 83 pacientes do sexo feminino com PPC e quatro pacientes do sexo masculino com PPC, respectivamente. 


\subsection{Avaliação hormonal}

O diagnóstico laboratorial da puberdade precoce central foi baseado nas dosagens das gonadotropinas (LH e FSH) e dos esteróides sexuais (estradiol e testosterona). No período do estudo foram utilizados dois métodos de dosagens para as gonadotropinas séricas: o radioimunoensaio (RIE) com duplo anticorpo (Wallac, Turku, Finlândia) ou o ensaio imunofluorométrico (IFMA) (Perkin Elmer, Wallac, Finlândia).

O teste de estímulo com $\mathrm{GnRH}$ de ação curta foi realizado pela administração de $100 \mu \mathrm{g}$ de gonadorelina intravenosa no tempo zero e coleta de sangue nos tempos $-15,0,15,30,45$ e 60 minutos. Os valores de esteróides sexuais e de LH e FSH basais e após estímulo com GnRH considerados normais, estão descritos nas Tabelas 3 e 4.

As concentrações puberais dos hormônios do eixo gonadotrófico foram: $\mathrm{LH}$ basal > 0,6 U/L ou após estímulo com $\mathrm{GnRH}>$ 6,9 U/L para o IFMA [90]; $\mathrm{LH}$ (delta) após estímulo com $\mathrm{GnRH}>15 \mathrm{U} / \mathrm{L}$, para o RIE. Adicionalmente, concentrações de estradiol superior a $13 \mathrm{pg} / \mathrm{mL}$ para o IFMA e $10 \mathrm{pg} / \mathrm{mL}$ para o RIE foram consideradas púberes [91]. No sexo masculino, foram considerados concentrações puberais: $\mathrm{LH}$ basal $>0,6 \mathrm{U} / \mathrm{L}$ ou após estímulo com GnRH > 9,6 U/L [90]; LH (delta) após estímulo com GnRH > 15 U/L [91], para o RIE. Adicionalmente, concentrações de testosterona superior a $14 \mathrm{ng} / \mathrm{dL}$ para o IFMA e $10 \mathrm{ng} / \mathrm{dL}$ para o RIE foram consideradas púberes. Além disso, LH > $10 \mathrm{U} / \mathrm{L}$, dosado duas horas após administração da primeira ampola de acetato de leuprolida 3,75 mg via subcutânea, também foi considerado como resposta puberal para ambos os sexos [92]. 
Tabela 1. Dados clínicos dos pacientes do sexo feminino com PPC. IC: idade cronológica; E: estatura; IO: idade óssea; IE: idade estatural; Z score: desvio padrão de estatura; PP: pêlos pubianos (estádio segundo critérios de Tanner); EA: estatura alvo; E2: estradiol, mamas: estádio segundo critérios de Tanner, * Exames realizados por radioimunoensaio (RIE). Os demais exames foram realizados por IFMA

\begin{tabular}{|c|c|c|c|c|c|c|c|c|c|c|c|c|c|c|c|}
\hline Paciente & $\begin{array}{c}\text { IC início } \\
\text { puberdade }\end{array}$ & $\begin{array}{l}\text { IC início } \\
\text { tratamento }\end{array}$ & $\mathrm{E}(\mathrm{cm})$ & $\begin{array}{c}10 \\
\text { (anos) }\end{array}$ & $\begin{array}{c}\text { IE } \\
\text { (anos) }\end{array}$ & $\begin{array}{c}\text { Z } \\
\text { score }\end{array}$ & $\begin{array}{l}\text { peso } \\
(\mathrm{kg})\end{array}$ & Mamas & PP & $\mathrm{EA}(\mathrm{cm})$ & $\begin{array}{l}\text { LH } \\
\text { (U/L) }\end{array}$ & $\begin{array}{l}\text { FSH } \\
\text { (U/L) }\end{array}$ & $\begin{array}{c}\text { E2 } \\
\text { (pg/mL) }\end{array}$ & $\begin{array}{l}\text { LH pós } \\
\text { GnRH }\end{array}$ & $\begin{array}{l}\text { LH } 2 \mathrm{~h} \text { pós } \\
\text { lupron }\end{array}$ \\
\hline 1 & 5,8 & 6,6 & 129,5 & 11 & 9 & 2,5 & 30 & 4 & 2 & 166 & 1,9 & 6,2 & 53,3 & 31,5 & \\
\hline 2 & 6,5 & 10,2 & 131,7 & 11 & 9 & $-0,1$ & 37 & 4 & 5 & 153 & 4,2 & & 98,8 & & \\
\hline 3 & 6,8 & 9,8 & 141,4 & 11,5 & 11 & 0,7 & 34,8 & 3 & 4 & 153 & 1,7 & 4,6 & $<13$ & & \\
\hline 4 & 5,5 & 8 & 132 & 11 & 9 & 1,2 & 28,2 & 3 & 4 & 160,5 & 1 & 1,9 & 17,4 & & 8,8 \\
\hline 5 & 5 & 8,2 & 140 & 11 & 10,5 & 1,9 & 39,2 & 4 & 1 & 158,5 & 1,7 & 3,9 & 34,6 & & 34,1 \\
\hline 6 & 4,5 & 7 & 129 & 7,8 & 8,7 & 2,0 & 26,3 & 3 & 1 & 158,5 & $<0,6$ & 1,6 & $<13$ & 11,4 & \\
\hline 7 & 6 & 7,3 & 129,5 & 9 & 8,7 & 1,3 & 38,2 & 3 & 1 & 157,5 & $<0,6$ & & $<13$ & 8,1 & \\
\hline 8 & 4 & 5,2 & 116,5 & 6,8 & 6,3 & 1,2 & 19,6 & 3 & 1 & 158,5 & $<0,6$ & 2 & $<13$ & 16,9 & 13,4 \\
\hline 9 & 6 & 8,7 & 141,5 & 12 & 10,7 & 2,1 & 33,2 & 4 & 4 & 153,5 & 1,2 & & 19,8 & & \\
\hline 10 & 1,2 & 2,7 & 100,5 & 6,8 & 4 & 2,8 & 18,3 & 4 & 4 & 168,7 & $2,6^{*}$ & & 4,4 & $30 *$ & \\
\hline 11 & 0,7 & 1,7 & 83 & 2 & 1,7 & 0 & 12,4 & 4 & 3 & 144,5 & 1,1 & 4,3 & 60,4 & 21 & 13,1 \\
\hline 12 & 3,2 & 3,4 & 106 & 6,8 & 5 & 2,3 & 19,1 & 4 & 1 & 149 & 5 & 9,8 & $<13$ & 89.7 & \\
\hline 13 & 6,3 & 6,7 & 124 & 10 & 8 & 1,4 & 25,7 & 2 & 1 & & 0,7 & & 45 & 7,5 & \\
\hline 14 & 2,3 & 7,2 & 136,4 & 11 & 10 & 3,1 & 37,7 & 3 & 2 & 155,5 & 0,9 & & $<13$ & & \\
\hline 15 & 2,3 & 4,7 & 118,8 & 8,8 & 6,8 & 2,3 & 24,7 & 4 & 1 & 160 & 0,7 & 1,5 & 19,1 & 18,8 & \\
\hline 16 & 6 & 6,4 & 123,1 & 8,8 & 7,6 & 0,7 & 26,6 & 2 & 2 & & $<0,6$ & & $<10^{*}$ & 9,5 & \\
\hline 17 & 5,8 & 9,7 & 135 & 12 & 9,6 & 0,1 & 39,3 & 4 & 3 & 153,5 & 0,7 & 1,7 & $<13$ & & 13,2 \\
\hline 18 & 3,2 & 6,5 & 136 & 8,8 & 10 & 3,7 & 30,4 & 4 & 3 & 169,5 & $<0,6$ & 3,7 & $<13$ & 4,2 & 10 \\
\hline 19 & 6,5 & 8,1 & 136,8 & 12 & 10 & 2,0 & 33,6 & 3 & 3 & & 1,5 & & 21,1 & 76,9 & \\
\hline 20 & 6,4 & 7,8 & 141,5 & 11 & 10,5 & 3,0 & 32,8 & 3 & 4 & & 1 & & 15 & 12 & \\
\hline 21 & 3,2 & 5,2 & 129,4 & 12 & 8,8 & 3,5 & 30 & 4 & 3 & 148 & $4,9^{\star}$ & & $14^{*}$ & $23,7^{*}$ & \\
\hline 22 & 6,7 & 7,5 & 128,4 & 10 & 8,2 & 0,9 & 38,8 & 3 & 2 & 156,5 & 1,4 & 2 & $<13$ & 20 & 23 \\
\hline 23 & 6,8 & 7,8 & 125,5 & 8,8 & 8,2 & 0,1 & 27,9 & 3 & 3 & 153,5 & $2,8^{\star}$ & 4,5 & $<10^{*}$ & $41^{*}$ & \\
\hline 24 & 4 & 6,8 & 136 & 9,5 & 9,5 & 3,2 & 31,3 & 4 & 3 & 153 & 6,1 & 4,7 & 62 & & \\
\hline 25 & 2,3 & 7,6 & 140,3 & 11 & 10,5 & 2,7 & 34,4 & 2 & 3 & 161,5 & 2,2 & 6 & 21 & 9,8 & \\
\hline 26 & 2 & 4,8 & 115 & 8 & 6,3 & 2,4 & 23,3 & 3 & 1 & & $3,8^{*}$ & $16.3^{*}$ & $23^{*}$ & $28,8^{\star}$ & \\
\hline 27 & 0,3 & 8,6 & 131,5 & 11 & 9,2 & 0,6 & 26,7 & 4 & 2 & adotiva & 0,5 & 1 & 22 & 6,4 & 8,5 \\
\hline 28 & 5 & 8,4 & 133 & 11 & 9,5 & 0,9 & 30,5 & 3 & 2 & 157 & $<0,6$ & $<1,0$ & 13 & 2,3 & \\
\hline 29 & 4 & 7 & 128,7 & 11 & 8,7 & 1,5 & 31,3 & 3 & 2 & 155,5 & 0,7 & $<1,0$ & $<13$ & & 4,2 \\
\hline 30 & 6 & 8,7 & 157,2 & 12 & 10,5 & 1,6 & 39,7 & 5 & 4 & 157,2 & 1,5 & 5,9 & 62,2 & 13,5 & \\
\hline
\end{tabular}


Continuação Tabela 1

\begin{tabular}{|c|c|c|c|c|c|c|c|c|c|c|c|c|c|c|c|}
\hline Paciente & $\begin{array}{c}\text { IC início } \\
\text { puberdade }\end{array}$ & $\begin{array}{l}\text { IC início } \\
\text { tratamento }\end{array}$ & $E(\mathrm{~cm})$ & $\begin{array}{c}10 \\
\text { (anos) }\end{array}$ & $\begin{array}{c}\text { IE } \\
\text { (anos) }\end{array}$ & $\begin{array}{c}Z \\
\text { score }\end{array}$ & $\begin{array}{c}\text { peso } \\
(\mathrm{kg})\end{array}$ & Mamas & PP & $\mathrm{EA}(\mathrm{cm})$ & $\begin{array}{l}\text { LH } \\
\text { (U/L) }\end{array}$ & $\begin{array}{l}\text { FSH } \\
\text { (U/L) }\end{array}$ & $\begin{array}{c}\mathrm{E2} \\
(\mathrm{pg} / \mathrm{mL})\end{array}$ & $\begin{array}{l}\text { LH pós } \\
\text { GnRH }\end{array}$ & $\begin{array}{c}\text { LH 2h pós } \\
\text { lupron }\end{array}$ \\
\hline 31 & 6 & 8 & 127,8 & 11 & 8,6 & 0,5 & & 3 & 3 & & 1 & & 17,4 & 8 & \\
\hline 32 & 6 & 8,2 & 128,6 & 12 & 8,7 & 0,4 & 30,7 & 3 & 2 & 152,2 & $<0,6$ & 2,7 & 13,4 & 5,3 & 12 \\
\hline 33 & & 6,8 & 125 & 7,8 & 8 & 1,2 & & 3 & 1 & & $3,5^{\star}$ & & $<10^{*}$ & $35,0^{*}$ & \\
\hline 34 & 7 & 8 & 136 & 12 & 10 & 1,9 & 35 & 4 & 3 & 157,5 & 1,2 & 4,1 & 20,5 & & 50,4 \\
\hline 35 & 7 & 8,7 & 135,4 & 11 & 9,8 & 0,9 & 32,6 & 3 & 3 & 154,5 & 1,2 & 1,8 & 13,1 & 19 & \\
\hline 36 & 7 & 8,9 & 135,3 & 11 & 9,8 & 0,8 & 29 & 3 & 4 & 155,5 & $<0,6$ & 2 & 40 & 8 & \\
\hline 37 & & 8,4 & 146,7 & 12 & 11,8 & 2,1 & 51,5 & 4 & 5 & 155,5 & 5,4 & 4,4 & 53,4 & & \\
\hline 38 & 2,8 & 4,2 & 106,6 & 6,8 & 4,8 & 1,2 & 19,5 & 4 & 1 & 158 & 0,6 & 4,2 & 18,2 & 13,5 & \\
\hline 39 & 6 & 9,8 & 129 & 11 & 8,8 & -1 & 27 & 4 & 3 & 147 & 0,8 & 3,5 & 22,2 & & \\
\hline 40 & 7 & 8,5 & 141,8 & 12 & 10,8 & 2,4 & 42 & 3 & 3 & adotiva & 1,1 & 5,6 & 35 & & 10,3 \\
\hline 41 & 7 & 8,6 & 142,4 & 11 & 11 & 2,3 & 31,6 & 3 & 1 & 165 & & & 17 & & 15,1 \\
\hline 42 & 7,3 & 8 & 148,5 & 11 & 11,8 & 4 & 42,2 & 3 & 3 & 171,5 & 1,5 & 2,7 & $<13$ & & 45,8 \\
\hline 43 & 6,8 & 8,2 & 139 & 11,5 & 10,3 & 2,3 & 38,3 & 4 & 3 & 158,5 & 1,5 & 5,6 & 46,3 & & \\
\hline 44 & 6,8 & 7,5 & 129,5 & 8,8 & 8,8 & 1,3 & 30,8 & 3 & 1 & 157,3 & 1,2 & 3,9 & 15 & 27,6 & \\
\hline 45 & 5 & 7,6 & 135,1 & 11,4 & 9,8 & 2,1 & 27 & 4 & 1 & 148,5 & 1,6 & 2,8 & 26,8 & 29,4 & \\
\hline 46 & 5 & 7,8 & 127,2 & 10 & 8,3 & 1,6 & 28 & 4 & 3 & & 1,6 & 4,7 & 29 & & 23,5 \\
\hline 47 & 6 & 7,8 & 143,5 & 11 & 11,2 & 3,4 & 31,1 & 3 & 3 & 168 & $<0,6$ & 1,2 & $<13$ & 6,9 & 7,7 \\
\hline 48 & 7 & 8 & 135 & 11 & 9,5 & 1,7 & 25,5 & 3 & 1 & 153 & $<0,6$ & 3,4 & 38 & 9,9 & \\
\hline 49 & 6 & 6,7 & 120,9 & 8,8 & 7,2 & 0,5 & 27,1 & 3 & 2 & 156,5 & 1,6 & 4,6 & & & \\
\hline 50 & 7 & 9,7 & 135 & 11 & 9,8 & 0 & 28,9 & 4 & 3 & 160 & 3,7 & 3,6 & 16 & & \\
\hline 51 & 6 & 8,2 & 142,6 & 11 & 11 & 2,7 & 36,5 & 3 & 3 & 174,5 & 2,1 & 1,2 & 15 & & \\
\hline 52 & 5 & 9,1 & 143,2 & 12 & 11,1 & 1,9 & 39,6 & 3 & 3 & 170,5 & 0,9 & 4,1 & 22 & & 27,8 \\
\hline 53 & 6 & 8,5 & 141 & 10 & 10,8 & 1 & 30 & 4 & 3 & 158,2 & $<0,6$ & 3 & $<13$ & 24 & \\
\hline 54 & 6 & 7,6 & 130 & 11 & 9 & 1 & 30,7 & 3 & 2 & 149 & $<0,6$ & $<1,0$ & 14,4 & 3,3 & 4,4 \\
\hline 55 & 6,2 & 7 & 114 & 7 & 6,2 & 0 & 19,8 & 3 & & & $<0,6$ & 1,1 & 13,2 & 36 & \\
\hline 56 & 7,7 & 8,2 & 133,2 & 11 & 9,4 & 1,1 & 28,6 & 3 & 3 & 166,5 & $<0,6$ & 4,2 & 31 & & 17,6 \\
\hline 57 & 7,6 & 7,7 & 132,2 & 8,8 & 9,3 & 1,4 & 33,6 & 3 & 2 & 163,5 & 1 & 5,3 & 69,9 & & \\
\hline 58 & 6,7 & 7,3 & 133,2 & 8,8 & 9,5 & 2,2 & 33,8 & 4 & 2 & 155,6 & 0,3 & 3,7 & 27,2 & 16,9 & 16 \\
\hline 59 & 3 & 7,5 & 133,3 & 11,6 & 9,5 & 2 & 33,3 & 2 & 1 & 160,5 & 0,8 & 5,4 & 33 & 4,1 & 8,6 \\
\hline 60 & 8 & 8,5 & 121 & 11 & 7,3 & $-1,1$ & 24 & 3 & 1 & 149,2 & $<0,6$ & 3,1 & 34,2 & & 16,3 \\
\hline
\end{tabular}


Conclusão Tabela 1

\begin{tabular}{|c|c|c|c|c|c|c|c|c|c|c|c|c|c|c|c|}
\hline Paciente & $\begin{array}{l}\text { IC início } \\
\text { puberdade }\end{array}$ & $\begin{array}{l}\text { IC início } \\
\text { tratamento }\end{array}$ & $E(\mathrm{~cm})$ & $\begin{array}{c}10 \\
\text { (anos) }\end{array}$ & $\begin{array}{c}\text { IE } \\
\text { (anos) }\end{array}$ & $\begin{array}{c}\mathrm{Z} \\
\text { score }\end{array}$ & $\begin{array}{l}\text { peso } \\
(\mathrm{kg})\end{array}$ & Mamas & PP & $\mathrm{EA}(\mathrm{cm})$ & $\begin{array}{l}\text { LH } \\
\text { (U/L) }\end{array}$ & $\begin{array}{l}\text { FSH } \\
\text { (U/L) }\end{array}$ & $\begin{array}{c}\mathrm{E2} \\
(\mathrm{pg} / \mathrm{mL})\end{array}$ & $\begin{array}{l}\text { LH pós } \\
\text { GnRH }\end{array}$ & $\begin{array}{l}\text { LH 2h pós } \\
\text { lupron }\end{array}$ \\
\hline 61 & 7 & 9,1 & 142,5 & 11 & 11 & 1,8 & 43,6 & 4 & 3 & 163,2 & 0,7 & 3,6 & 30 & 5,1 & \\
\hline 62 & 7 & 8,2 & 133 & 11 & 9,4 & 0,9 & 31,6 & 3 & 2 & & 0,6 & 3,5 & 46 & & \\
\hline 63 & 0 & 8,3 & 132,2 & 11 & 9,3 & 0,9 & 28 & 4 & 1 & 158,5 & 1,3 & 3 & 14,6 & 15,1 & \\
\hline 64 & 7,9 & 8,5 & 143,6 & 11 & 11,3 & 2,6 & 39,2 & 3 & 2 & 162 & 0,88 & 2,1 & 16 & & \\
\hline 65 & 0,9 & 1,3 & 83,5 & 2,3 & 2,5 & 2,4 & 12,4 & 2 & 2 & 164,8 & 3,2 & 5,9 & 58,1 & 88 & \\
\hline 66 & 6,6 & 7,2 & 142,2 & 11,5 & 11,2 & 4 & 33,9 & 3 & 3 & 166,5 & 1,3 & 5,3 & 13 & 11,9 & \\
\hline 67 & 7,6 & 7,5 & 127 & 10 & 8,5 & 0,2 & 27,9 & 3 & 1 & 152,5 & $<0,6$ & 1,4 & $<13$ & 5 & \\
\hline 68 & 2,1 & 4,2 & 104 & 5,9 & 2,6 & 0,7 & 20,5 & 3 & 1 & 160,7 & $<0,6$ & 3,5 & 13 & 9,1 & \\
\hline 69 & 7,6 & & 135 & 8,9 & 10 & 2,3 & 36,3 & 2 & 3 & 168,7 & $<0,6$ & 2,2 & 18 & 8,9 & \\
\hline 70 & 1 & & 84,3 & 2,8 & 1,9 & 2,7 & 16,5 & 3 & 2 & 157 & 3,2 & 6,3 & 48 & 142,7 & \\
\hline 71 & 7,8 & 8,3 & 147,5 & 10 & 11,6 & 3,7 & 46 & 3 & 3 & 170,3 & 1,4 & 6,7 & 41 & 11,4 & \\
\hline 72 & 7,8 & 8,8 & 141,5 & 10 & 11,4 & 2,3 & 38,8 & 3 & 3 & 165,7 & 1,5 & 4,6 & 35 & 8,6 & \\
\hline 73 & 7,9 & 8 & 140 & 11 & 10,6 & 2,4 & 41,1 & 3 & 2 & 160,5 & $<0,6$ & $<1,0$ & $<13$ & 20,4 & 8,3 \\
\hline 74 & 6,6 & 8,5 & 128,2 & 11 & 10 & 1,07 & 30,6 & 3 & 1 & 158,25 & $<0,6$ & 4,2 & 18 & 10 & \\
\hline 75 & 7 & & 146 & 12,5 & 12 & 3,3 & 36 & 4 & 4 & 164,5 & $<0,6$ & 1,7 & 57 & 20,5 & \\
\hline 76 & 6,3 & 7,2 & 133,6 & 8,9 & 9,2 & 2,58 & 30,5 & 3 & 3 & 163,7 & 4,3 & 3,7 & 38 & 38,7 & \\
\hline 77 & 0,8 & 1,3 & 85 & 2,6 & 2,4 & 2,84 & 16,1 & 3 & 2 & 157,5 & 1,1 & 4,2 & & 20,3 & \\
\hline 78 & 7,3 & 7,8 & 142 & 11 & 10,9 & 3,1 & 40,7 & 3 & 3 & & 2 & 6,8 & 13 & & \\
\hline 79 & 6 & 8,3 & 140,3 & 11 & 10,7 & 2,3 & 27,3 & 2 & 3 & 161 & $<0,6$ & 1,4 & $<13$ & 11,3 & \\
\hline 80 & 7 & 7,8 & 138,5 & 11 & 10,3 & 2,5 & 41,5 & 3 & 3 & 166,5 & 1,2 & 3,4 & 35,2 & 17,9 & \\
\hline 81 & 0 & 5,1 & 113,7 & 4,1 & 6,1 & 1,1 & 18 & 4 & 1 & & $<0,6$ & 4,6 & 15,9 & 11,4 & \\
\hline 82 & 5,5 & 7,4 & 135,1 & 11 & 9,8 & 2,3 & 33,2 & 4 & 3 & 160,5 & 2,1 & 4,8 & 16 & & \\
\hline 83 & 1,3 & 2,3 & 92,7 & 2,5 & 3 & 1,5 & 13,2 & 4 & 1 & 168,7 & $<0,6$ & 1,7 & & 8,8 & \\
\hline
\end{tabular}


Tabela 2. Dados clínicos dos pacientes do sexo masculino com PPC. IC: idade cronológica; E: estatura; IO: idade óssea; IE: idade estatural; Z score: desvio padrão de estatura; PP: pêlos pubianos (estádio segundo critérios de Tanner); EA: estatura alvo; T: testosterona, pênis: comprimento em cm; * Exames realizados por radioimunoensaio (RIE). Os demais exames foram realizados por IFMA

\begin{tabular}{|c|c|c|c|c|c|c|c|c|c|c|c|c|c|c|c|}
\hline Paciente & $\begin{array}{l}\text { IC início } \\
\text { puberdade }\end{array}$ & $\begin{array}{l}\text { IC início } \\
\text { tratamento }\end{array}$ & $E(\mathrm{~cm})$ & $\begin{array}{c}10 \\
\text { (anos) }\end{array}$ & $\begin{array}{c}\mathrm{IE} \\
\text { (anos) }\end{array}$ & $\begin{array}{c}Z \\
\text { score }\end{array}$ & $\begin{array}{l}\text { peso } \\
(\mathrm{kg})\end{array}$ & Pênis & PP & $\begin{array}{l}\text { EA } \\
(\mathbf{c m})\end{array}$ & $\begin{array}{l}\text { LH } \\
\text { (U/L) }\end{array}$ & $\begin{array}{l}\text { FSH } \\
\text { (U/L) }\end{array}$ & $\begin{array}{c}\mathbf{T}^{\mathrm{T}} \\
(\mathrm{ng} / \mathrm{dL})\end{array}$ & $\begin{array}{l}\text { LH pós } \\
\text { GnRH }\end{array}$ & $\begin{array}{l}\text { LH } 2 \mathrm{~h} \text { pós } \\
\text { lupron }\end{array}$ \\
\hline 1 & 2,3 & 5,2 & 129 & 13 & 8,5 & 4,4 & 27,9 & 10,5 & 4 & 178,5 & 1,1 & 1,1 & 92 & & 28 \\
\hline 2 & 1 & 1,4 & 85 & 2,6 & 1,8 & 0,5 & 14,3 & 2 & 2 & 165 & $11.5^{*}$ & $8,3^{*}$ & $600^{*}$ & 47.2 * & 29 \\
\hline 3 & 6 & 8,1 & 131 & 10 & 8,9 & 0,8 & 30,5 & 8 & 1 & 167 & 1,2 & 1,5 & 116 & & 14,1 \\
\hline 4 & 8 & 10,7 & 150 & 13,5 & 12,5 & 1,4 & 43,2 & 9 & 4 & 166,2 & 1,7 & 1,8 & 312 & & \\
\hline
\end{tabular}


Tabela 3. Valores normais de testosterona e LH no sexo masculino, obtidos nos ensaios IFMA e RIE em pré-púberes e adultos

\begin{tabular}{ccccc} 
& $\begin{array}{c}\text { Testosterona } \\
\text { ng/dL }\end{array}$ & $\begin{array}{c}\text { LH basal } \\
\text { U/L }\end{array}$ & $\begin{array}{c}\text { LH pico* } \\
\text { U/L }\end{array}$ & Ensaio \\
& $<14$ & $\leq 0,6$ & $<9,6$ & IFMA \\
Pré-púberes & $200-950$ & $1,4-9,2$ & $12-29,7$ & \\
Adultos & & & & RIE \\
Pré-púberes & $<10$ & & Delta $<15$ & \\
Adultos & $350-1090$ & & Delta $\geq 15$ & \\
\hline
\end{tabular}

* após $100 \mu \mathrm{g}$ de gonadorelina i.v.

Tabela 4. Valores normais de estradiol e LH no sexo feminino, obtidos nos ensaios de IFMA e RIE em pré-púberes e adultos

\begin{tabular}{lcccc}
\hline & $\begin{array}{c}\text { Estradiol } \\
\text { pg/mL }\end{array}$ & $\begin{array}{c}\text { LH basal } \\
\text { U/L }\end{array}$ & $\begin{array}{c}\text { LH pico* } \\
\text { U/L }\end{array}$ & Ensaio \\
& $<13$ & $\leq 0,6$ & $<6,9$ & IFMA \\
Pré-púberes & $30-94$ & $1,0-8,4$ & $7,6-31,7$ & \\
$\begin{array}{c}\text { Adultas fase } \\
\text { folicular }\end{array}$ & & & & \\
& & & DIE \\
$\begin{array}{c}\text { Pré-púberes } \\
\text { Adultas fase } \\
\text { folicular }\end{array}$ & $10-80$ & & Delta $\geq 15$ & \\
\hline
\end{tabular}

* após $100 \mu \mathrm{g}$ de gonadorelina i.v. 


\subsection{Pesquisa de mutações}

\subsubsection{Extração do DNA genômico de leucócitos a partir de sangue periférico}

O DNA genômico foi extraído de $12 \mathrm{~mL}$ de sangue periférico colhido em tubo com EDTA. O sangue foi incubado em solução para lise de glóbulos vermelhos (114 mM cloreto de amônia; 1 mM carbonato de amônia) durante 30 minutos a $4^{\circ} \mathrm{C}$. Após este período, a amostra foi centrifugada a $3.000 \mathrm{rpm}$ durante 15 minutos a $4^{\circ} \mathrm{C}$. O sobrenadante foi descartado, o botão de células foi ressuspenso em solução tampão constituída de 100 mM NaCl; 10 mM Tris$\mathrm{HCl} \mathrm{pH} \mathrm{8,0;} 1$ mM EDTA pH 8,0 contendo 1\% SDS e 0,2 mg/mL proteinase $\mathrm{K}$ e mantido durante a noite a $37^{\circ} \mathrm{C}$. No dia seguinte, a amostra foi submetida a duas extrações com fenol:clorofórmio:álcool isoamílico (25:24:1) e a uma extração com clorofórmio e álcool isoamílico (24:1). O DNA foi precipitado com acetato de sódio 0,3 M em pH 7,0 e com 2 volumes de etanol absoluto gelado. Posteriormente, o DNA foi lavado em etanol $70 \%$ por 5 minutos e ressuspenso em TE (10 mM Tris- $\mathrm{HCl}$ pH 8,0; 0,1 mM EDTA pH 8,0).

A concentração do DNA foi estimada a partir da leitura da densidade óptica por espectrofotometria com luz ultravioleta (Ultrospec III- Pharmacia Biotech, EUA); o grau de pureza foi avaliado pela relação A260/280, sendo desejado um valor próximo de 1,8. A integridade do material foi verificada com eletroforese em gel de agarose 1\% e visualização por transluminação com luz ultravioleta após coloração com solução de brometo de etídio. As amostras foram armazenadas a $4^{\circ} \mathrm{C}$ até sua utilização. 


\subsubsection{Amplificação de DNA genômico por reação em cadeia da polimerase (PCR)}

O DNA genômico obtido foi utilizado como substrato para a amplificação dos três exons do gene KISS1 (número de acesso do Genbank, MIM: 603286) e da região promotora proximal, incluindo 1 kb da região 5' a montante do sítio de início de transcrição, dos cinco exons do gene KISS1R (MIM: 604161) e dos quatro exons do gene LIN28B (MIM: 611044), por meio da reação em cadeia da polimerase (PCR), utilizando-se pares de oligonucleotídeos intrônicos específicos (Tabela 5). Os oligonucleotídeos específicos foram desenhados utilizando-se o programa computacional Primer3 (http://fokker.wi.mit.edu/primer3/primer3_code.html). 
Tabela 5. Oligonucleotídeos utilizados para amplificação dos genes KISS1, KISS1R e LIN28B

\begin{tabular}{|c|c|c|c|}
\hline $\begin{array}{l}\text { Gene/Região } \\
\text { amplificada }\end{array}$ & Oligonucleotídeos específicos & $\begin{array}{l}\text { Tamanho do } \\
\text { Fragmento (pb) }\end{array}$ & $\begin{array}{l}\text { Temperatura do } \\
\text { Anelamento }\left({ }^{\circ} \mathrm{C}\right)\end{array}$ \\
\hline KISS1/promotora2 & $\begin{array}{l}\text { 5'-GAG CGT CCT GTC TGA GGG TA-3' } \\
\text { 5'-AGA GAG GGG ACT TCC AGG TG-3' }\end{array}$ & 353 & 56 \\
\hline KISS1/promotora1 & $\begin{array}{l}\text { 5'-ACC TGG AAG TCC CCT CTC TG-3' } \\
\text { 5'-AGC CTC TGA GGT GAC GAG AC-3' }\end{array}$ & 812 & 55 \\
\hline KISS1/Exon1 & $\begin{array}{l}\text { 5'-GGG CTT TAT AAA AGG GAT GTG-3' } \\
\text { 5'- GTC TTA GAA CGG ATT CCC TG-3' }\end{array}$ & 240 & 58 \\
\hline KISS1/Exon2 & $\begin{array}{l}\text { 5'-CAG ATC CTG TGC CTG ACC T-3' } \\
\text { 5'-TTG CAA CAA CCC АCT TGC T-3' }\end{array}$ & 238 & 60 \\
\hline KISS1/Exon3 & $\begin{array}{l}\text { 5'-GTG TTG CAA AGC CAT CTT TC-3' } \\
\text { 5'-TCT TTT ATT GCC TCG GGT TG-3' }\end{array}$ & 500 & 57 \\
\hline KISS1R/Exon1 & $\begin{array}{l}\text { 5'-GCT GGG TGA ATA GAG GGC-3' } \\
\text { 5'-GGA GTT TGC GAC CTC TAG C-3' }\end{array}$ & 721 & 60 \\
\hline KISS1R/Exon2 & $\begin{array}{l}\text { 5'-CCA TCC TGC TGG TCA CTC G-3' } \\
\text { 5'-CAC TGC GGA GCG CAC TCC-3' }\end{array}$ & 303 & 55 \\
\hline KISS1R/Exon3 & $\begin{array}{l}\text { 5'-GCC TGA GTG TTC GCA CAC G-3' } \\
\text { 5'-GCG CCC ATT TTC CAG ATG C-3' }\end{array}$ & 340 & 55 \\
\hline KISS1R/Exon4 & $\begin{array}{l}\text { 5'-GCA TCT GGA AAA TGG GCG C-3' } \\
\text { 5'-GGA AGG CGT AGA GCA GCG-3' }\end{array}$ & 430 & 60 \\
\hline KISS1R/Exon5 & $\begin{array}{l}\text { 5'-GGA GGA CAG CAA GGC TGG-3' } \\
\text { 5'-AAA CTG CAC CGA ACG TCA CA-3' }\end{array}$ & 751 & 58 \\
\hline LIN28B/Exon1 & $\begin{array}{l}\text { 5'-GCC CCT TAA GGA TAC GAG GT-3' } \\
\text { 5'-GGA GGG GGA GGA GAA AAG AA-3' }\end{array}$ & 317 & 56 \\
\hline LIN28B/Exon2 & $\begin{array}{l}\text { 5'-TGT GGC TGA AAA ATG GAG TT-3' } \\
\text { 5'-ACA CGT ACC CTA AAC GTT GG-3' }\end{array}$ & 306 & 55 \\
\hline LIN28B /Exon3 & $\begin{array}{l}\text { 5'-TCT CCC ACT GCC AGT ATT GC-3' } \\
\text { 5'-ATG ATG GTG GTT TCC TTT GG-3' }\end{array}$ & 481 & 60 \\
\hline LIN28B /Exon4 & $\begin{array}{l}\text { 5'-ACC AGA ACA TTT TGG TGA TGA-3' } \\
\text { 5'-TCC CAG GTC AGC TAC TGC TT-3' }\end{array}$ & 560 & 60 \\
\hline
\end{tabular}


As reações foram realizadas em um volume final de $25 \mu \mathrm{L}$. Para cada reação foram utilizados 100 a 200 ng de DNA genômico, $200 \mu \mathrm{M}$ de cada desoxinucleotídeo (dNTP), 10 pmol de cada oligonucleotídeo, 1,25 U de enzima Taq polimerase (Amersham Pharmacia, Upsala, Suécia) e tampão da reação fornecido pelo fabricante contendo $1,5 \mathrm{mM}$ de $\mathrm{MgCl}_{2}$. A reação de amplificação foi realizada em um termociclador GeneAmp PCR System 2400 (Perkin-Elmer, Foster City, CA, EUA) e consistiu das seguintes etapas: desnaturação inicial a $95^{\circ} \mathrm{C}$ por 5 minutos, seguida por 35 ciclos de desnaturação a $94^{\circ} \mathrm{C}$ por 30 segundos, anelamento variando de 55 a $60^{\circ} \mathrm{C}$ por 30 segundos e extensão a $72^{\circ} \mathrm{C}$ por 1 minuto e extensão final a $72^{\circ} \mathrm{C}$ por 10 minutos. Os produtos de PCR foram submetidos à eletroforese em gel de agarose a $1 \%$, corados com brometo de etídio $(0,5 \mu \mathrm{g} / \mathrm{mL})$ e visualizados por transiluminação em luz ultravioleta.

\subsubsection{Sequenciamento automático}

A concentração de DNA dos produtos gerados pela PCR foi determinada a partir da comparação da intensidade de sinal emitido pelos fragmentos de um marcador de peso molecular de concentração conhecida em gel de agarose. Posteriormente, os produtos de amplificação foram submetidos à purificação enzimática, utilizando-se o produto comercial EXO-SAP contendo as enzimas Shrimp Alkaline Phosphatase e exonuclease I (Amersham Science, USB, Cleveland, Ohio, EUA). A reação de sequenciamento foi realizada utilizando o produto comercial ABI Prism ${ }^{T M}$ BigDye Terminator (Perkin Elmer, Foster City, $C A, E U A)$. Os produtos desta reação foram submetidos à eletroforese no 
sequenciador automático ABI Prism Genetic Analyzer 3100 automatic DNA sequencer (Perkin Elmer, Foster City, CA).

As sequênciais obtidas foram alinhadas através do software Sequencher4.7(http://bip.weizmann.ac.il/toolbox/target/dna/Sequencher_4.7_ PC_User_Manual.pdf) e comparadas com as sequências depositadas na base de dados do National Center for Biotechnology and Information (NCBI).

\subsubsection{Análise estatística dos polimorfismos}

Para comparar as frequências genotípicas e alélicas dos polimorfismos no KISS1 entre pacientes com PPC e controles, foram considerados apenas indivíduos não relacionados, incluindo somente o propósito de cada família com PPC, totalizando 91 pacientes com PPC. A distribuição genotípica e a frequência alélica entre pacientes com PPC e o grupo controle foram avaliadas em tabelas de contingência, pelo teste exato de Fisher ou pelo teste qui-quadrado $\left(\chi^{2}\right)$. Para a análise dos dados, foi utilizado o programa GraphPad Instat3 (San Diego, CA, EUA). Foram considerados significantes valores de $p<0,05$.

\subsubsection{Predição de mudança de sítio de splicing}

A predição dos potenciais sítios crípticos de splicing na ocorrência da perda do sítio constitutivo foi investigada por meio do programa computacional NetGene2 (http://genome.cbs.dtu.dk/services/NetGene2/). 


\subsubsection{Digestão por enzima de restrição}

Uma troca nucleotídica c.799A>G (p.H199R) localizada no exon 4 do LIN28B foi estudada no grupo controle pela técnica de digestão enzimática. A presença da base G leva à perda de um sítio de restrição para a enzima Nlalll (New England Biolabs, Beverly, MA, USA). Portanto, na presença da base $A$, o produto inicial de 380 pb é digerido em três fragmentos (201 pb, 71 pb e 38 pb), enquanto que na presença da base $\mathrm{G}$ ele é digerido em dois fragmentos (239 pb e 71 pb). A reação de digestão foi realizada utilizando 5 $\mu \mathrm{L}$ do produto de PCR do exon 4, 1,25 UI da enzima Nlalll e o tampão da reação fornecido pelo fabricante por três horas a $60^{\circ} \mathrm{C}$. O produto da digestão foi submetido à eletroforese em gel de agarose a $2 \%$ corado com brometo de etídio e fotografado sob luz ultravioleta.

\subsection{Estudos funcionais}

Os estudos funcionais foram desenvolvidos em colaboração com o laboratório do Doutor Richard Gregory, chefe do Departament of Biological Chemistry and Molecular Pharmacology, Harvard Medical School, Boston, EUA. 


\subsection{1- Clonagem e mutagênese sítio-dirigida}

Lin28B humano e a variante LIN28B H199R foram clonados no vetor pFLAG-CMV2 (Sigma). Lin28B H199R foi gerado por mutação sítio-dirigida com o produto comercial QuickChange ${ }^{\circledR}$ II Site-Directed Mutagenesis Kit (Stratagene, La Jolla, CA) e foi confirmada por seqüenciamento automático. Pri-let-7g murino foi clonado no vetor pcDNA3 (Invitrogen) e um vetor pSiCheck2-Luciferase repórter contendo sítios de ligação à let-7 na região 3’UTR também foi construído. [79]

\subsection{2- Cultura celular e transfecção}

As células HEK293 e Hella foram mantidas em meio de cultura Dulbecco's Modified Eagle's Medium (DMEM), suplementado com soro fetal bovino a 10\%, Pen/Strep, L-Glutamina, aminoácidos não essenciais (Gibco, Invitrogen) e incubadas a $37^{\circ} \mathrm{C}$, em $5 \% \mathrm{CO} 2$. As transfecções foram realizadas com a lipofectamina (Invitrogen) de acordo com as instruções do fabricante.

\subsection{3- Imunoprecipitação, Western Blotting e EMSA}

Lisados celulares foram preparados utilizando um tampão de lise (20 mM Tris/pH 8,0, $137 \mathrm{mM} \mathrm{NaCl,} 1 \mathrm{mM}$ EDTA, 1\% Triton X100, 10\% Glicerol, 1,5 mM MgCl $2,1 \mathrm{mM}$ DTT e inibidores de protease (Roche). Imunoprecipitações foram realizadas em microesferas de agarose-Flag 
(Sigma) durante 90 min a $4^{\circ} \mathrm{C}$. As microesferas foram lavadas com tampão de $\mathrm{KCl}$ 300mM. As eluições foram realizadas com peptídeo Flag (Sigma), separadas em géis de Tris-Glycine-SDS a 4-12\% (Invitrogen) e transferidas para membrana Immobilon-P PVDF (Millipore). Anticorpo anti-Flag-HRP (Sigma, A8592) foi utilizado na diluição 1:1000 em 5\% de leite por uma hora. Para o estudo de EMSA, foi utilizado um RNA pré-let-7 marcado radioativamente na região 5', como descrito previamente [93].

\subsection{4- Extração de RNA e PCR em Tempo Real}

O RNA foi extraído de células HEK293 utilizando-se o reagente Trizol (Invitrogen). Para a quantificação da expressão de miRNAs maduros foi utilizado o ensaio TaqMan microRNA assays (Applied Biosystems) como descrito previamente [83]. U18 foi utilizado como gene normalizador.

\subsection{5- Ensaio de luciferase}

Células Hela cultivadas em placas de seis poços foram cotransfectadas com $1 \mu \mathrm{g}$ dos plasmídeos com as sequências do LIN28B selvagem, LIN28B H199R, pri-let-7g e do gene repórter let-7. Células foram coletadas 48 horas após a transfecção. As transfecções foram realizadas em triplicata e os valores de luciferase foram avaliados utilizando-se o ensaio Dual Luciferase Assay System (Promega). 
4 RESULTADOS 


\subsection{Pesquisa de mutações e polimorfismos no gene KISS1}

Uma transição de uma citosina por uma guanina na posição 422 do cDNA do gene KISS1 (c.422C>G) (Figura 6), resultando na substituição de uma histidina por um ácido aspártico na posição 90 da kisspeptina-1 (p.H90D), foi identificada no exon 3 do gene KISS1 em quatro meninas não relacionadas com PPC [61]. Apenas duas destas meninas apresentaram a variante em homozigose. Identificamos apenas uma mutação p.P74S em 91 crianças com puberdade precoce central, anteriormente descrita [61]. A prevalência para a variante p.H90D foi $4,4 \%$ (4/91) e para a mutação p.P74S foi 1,1\% (1/91). Essas variantes estavam ausentes em 400 alelos controles analisados.

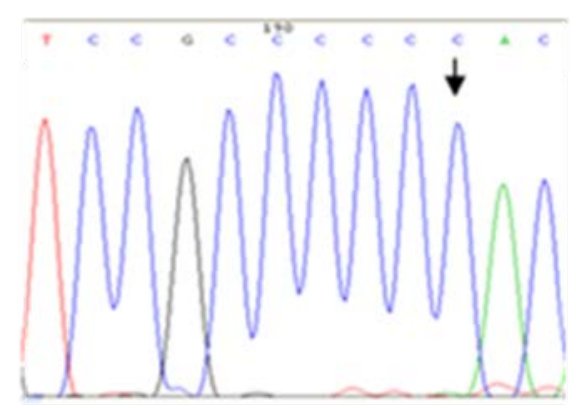

selvagem

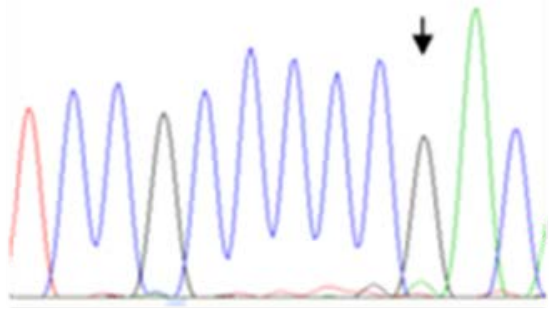

c. $422 \mathrm{C}>\mathrm{G}(\mathrm{p} . \mathrm{H} 90 \mathrm{D})$

Figura 6. Eletroferograma mostrando a substituição de uma citosina por uma guanina em homozigose no exon 3 do gene KISS1 (c.422C>G), em comparação com uma sequência normal 
Identificamos seis variantes polimórficas exônicas: duas na região 5' não traduzida (c.18delT e c.75G>A) e quatro na região codificadora, não sinônimas (c.221G>A, c.270A>G, c.405C>G e c.579_580insA) (Figura 7). Todos os polimorfismos encontrados haviam sido previamente descritos (ref seq CONTIG NT-004487.3 www.ncbi.nlm.nih.gov/SNP), e não houve diferença estatística nas frequências genotípicas e alélicas das variantes entre as populações estudadas (PPC e controles) (Tabelas 6 e 7). Um total de 91 crianças com PPC foi selecionado para o estudo do gene KISS1.

c.18delT

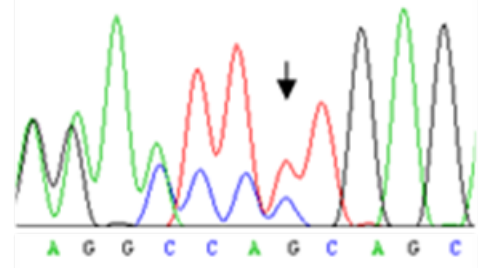

c. $270 \mathrm{~A}>\mathrm{G}$

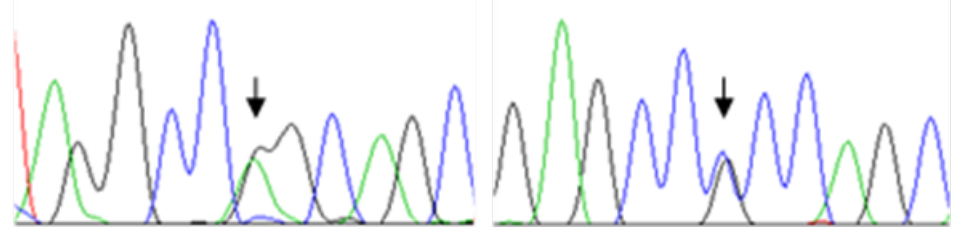

c. $75 \mathrm{G}>\mathrm{A}$

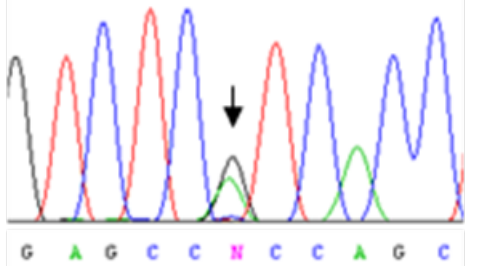

c. $405 \mathrm{C}>\mathrm{G}$

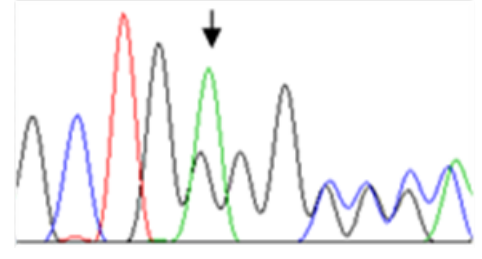

Figura 7. Eletroferograma mostrando as variantes polimórficas identificadas nos três exons do gene KISS1, incluindo regiões codificadoras e não traduzidas 
Tabela 6. Frequência alélica dos polimorfismos identificados nos exons 1 a 3 do gene KISS1 em pacientes com PPC e controles.

\begin{tabular}{|c|c|c|c|c|c|}
\hline EXON & Nucleotídeo & Ref seq & Proteína & $\begin{array}{c}\text { PPC } \\
(n=91)\end{array}$ & $\begin{array}{c}\text { Controles } \\
(n=200)\end{array}$ \\
\hline 1 & c.18delT & rs5780218 & 5'UTR & $\begin{array}{r}\text { T } 54 \% \\
-46 \%\end{array}$ & $\begin{array}{c}\text { T 64,3\% } \\
\_35,7 \%\end{array}$ \\
\hline 1 & c. $75 G>A$ & rs3924587 & 5'UTR & $\begin{array}{l}\text { G } 90 \% \\
\text { A } 10 \%\end{array}$ & $\begin{array}{c}\text { G 92\% } \\
\text { A 8\% }\end{array}$ \\
\hline 2 & c. $221 \mathrm{G}>\mathrm{A}$ & rs12998 & E20Q & $\begin{array}{c}\text { G } 97,3 \% \\
\text { A } 2,7 \%\end{array}$ & $\begin{array}{c}\text { G } 98,2 \% \\
\text { A } 1,8 \%\end{array}$ \\
\hline 3 & c. $270 A>G$ & rs35431622 & Q36R & $\begin{array}{c}\text { A } 93,5 \% \\
\text { G } 6,5 \%\end{array}$ & $\begin{array}{c}\text { A } 95,5 \% \\
\text { G } 4,5 \%\end{array}$ \\
\hline 3 & c. $405 C>G$ & rs1132112 & P81R & $\begin{array}{l}\text { C } 74 \% \\
\text { G } 26 \%\end{array}$ & $\begin{array}{l}\text { C } 67,2 \% \\
\text { G } 32,8 \%\end{array}$ \\
\hline 3 & c.579_580insA & rs4889 & $\begin{array}{l}\text { Omite } 7 \text { aa } \\
\text { (stop códon) }\end{array}$ & $\begin{array}{r}\text { A } 77,8 \% \\
-22,2 \%\end{array}$ & $\begin{array}{r}\text { A } 77,2 \% \\
-22,8 \%\end{array}$ \\
\hline
\end{tabular}

Tabela 7. Frequência genotípica dos polimorfismos identificados nos exons 1 a 3 do gene KISS1 em pacientes com PPC e controles

\begin{tabular}{|c|c|c|c|c|c|}
\hline EXON & Nucleotídeo & Ref seq & Proteína & $\begin{array}{c}\text { PPC } \\
(n=91)\end{array}$ & $\begin{array}{c}\text { Controles } \\
(n=200)\end{array}$ \\
\hline 1 & c.18delT & rs5780218 & 5'UTR & $\begin{array}{c}\text { T/T } 30,4 \% \\
\text { T/_48\% } \\
\text { I_ 21,6\% }\end{array}$ & $\begin{array}{c}\mathrm{T} / \mathrm{T} 40,5 \% \\
\mathrm{~T} / \_47,5 \% \\
\text { /_12\% }\end{array}$ \\
\hline 1 & c. $75 \mathrm{G}>\mathrm{A}$ & rs3924587 & 5'UTR & $\begin{array}{l}\text { G/G } 80 \% \\
\text { G/A 20\% }\end{array}$ & $\begin{array}{c}\text { G/G } 85 \% \\
\text { G/A } 14 \% \\
\text { A/A } 1 \%\end{array}$ \\
\hline 2 & c. $221 G>A$ & rs12998 & p.E20Q & $\begin{array}{c}\text { G/G 94\% } \\
\text { G/A 6\% }\end{array}$ & $\begin{array}{c}\text { G/G } 96,5 \% \\
\text { G/A 3,5\% }\end{array}$ \\
\hline 3 & c. $270 A>G$ & rs35431622 & p.Q36R & $\begin{array}{c}\text { A/A } 86,9 \% \\
\text { A/G 13,1\% } \\
\\
\end{array}$ & $\begin{array}{c}\text { A/A } 92 \% \\
\text { A/G } 7 \% \\
\text { G/G } 1 \% \\
\end{array}$ \\
\hline 3 & c. $405 C>G$ & rs1132112 & p.P81R & $\begin{array}{c}\text { C/C } 56,5 \% \\
\text { C/G } 34,8 \% \\
\text { G/G } 9,7 \% \\
\end{array}$ & $\begin{array}{c}\text { C/C } 41,5 \% \\
\text { C/G } 51.5 \% \\
\text { G/G 7\% }\end{array}$ \\
\hline 3 & c.579_580insA & rs4889 & $\begin{array}{l}\text { Omite } 7 \text { aa } \\
\text { (stop códon) }\end{array}$ & $\begin{array}{c}\text { AlA } 63 \% \\
A I_{-} 29,3 \% \\
\text { I_ } 7,7 \%\end{array}$ & $\begin{array}{c}\text { AlA } 59 \% \\
\text { Al_36,5\% } \\
\text { I_ } 4,5 \%\end{array}$ \\
\hline
\end{tabular}

$p>0,05$

_: Ausência de base nitrogenada 
$\mathrm{Na}$ região promotora, identificamos cinco variantes polimórficas: -936 delC, $-454 \mathrm{C}>\mathrm{T},-415 \mathrm{G}>\mathrm{A},-353 \mathrm{~T}>\mathrm{C}$ e $-60 \mathrm{G}>\mathrm{A}$ (Figura 8). Os SNPs $-454 \mathrm{~T}>\mathrm{C}, \quad-415 \mathrm{G}>\mathrm{A}, \quad-353 \mathrm{~T}>\mathrm{C}$ e $-60 \mathrm{G}>\mathrm{A}$ haviam sido previamente descritos (ref seq CONTIG NT-004487 www.ncbi.nlm.nih.gov/SNP). A freqüência genotípica e alélica das variantes polimórficas encontradas não foi estatisticamente diferente entre crianças com PPC e controles. (Tabelas 8 e 9).

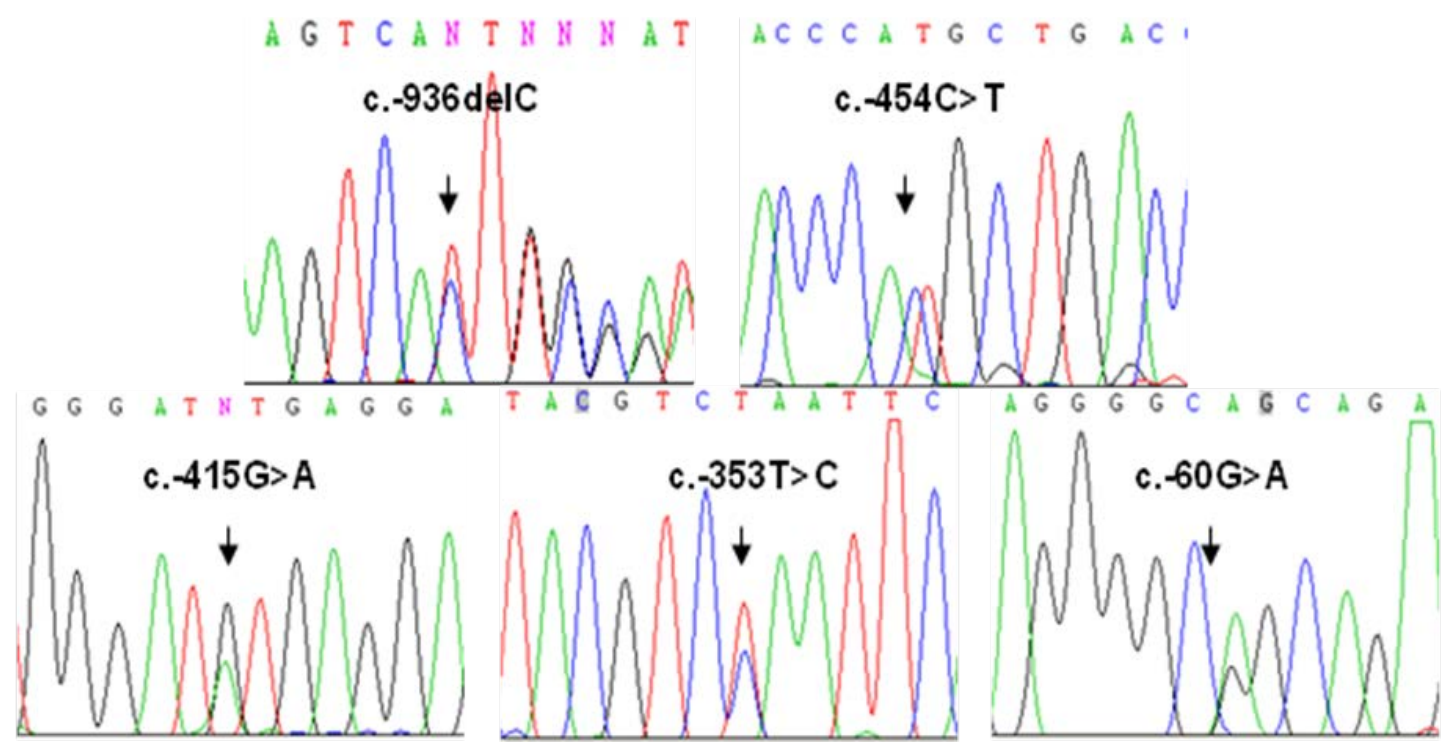

Figura 8. Eletroferograma mostrando as variantes polimórficas identificadas na região promotora do gene KISS1 
Tabela 8. Frequência alélica dos polimorfismos identificados na região promotora do gene KISS1 em pacientes com PPC e controles

\begin{tabular}{|c|c|c|c|}
\hline Nucleotídeo & Ref seq & $\begin{array}{c}\text { PPC } \\
(n=91)\end{array}$ & $\begin{array}{c}\text { Controles } \\
(n=200)\end{array}$ \\
\hline \multirow{2}{*}{-936 delC } & & C 90,8\% & C $91,9 \%$ \\
\hline & & $-9,2 \%$ & - 8,1\% \\
\hline \multirow{2}{*}{$-454 C>T$} & \multirow{2}{*}{ rs3924585 } & C 92\% & C $92,8 \%$ \\
\hline & & Т 8\% & Т 7,2\% \\
\hline \multirow{2}{*}{$-415 C>T$} & \multirow{2}{*}{ rs3924586 } & C 50,92\% & G $45,2 \%$ \\
\hline & & T 40,1\% & A $54,8 \%$ \\
\hline \multirow{2}{*}{$-353 T>C$} & \multirow{2}{*}{ rs56095702 } & Т 95,6\% & T 94,3\% \\
\hline & & C $4,4 \%$ & C $5,7 \%$ \\
\hline \multirow{2}{*}{$-60 G>A$} & \multirow{2}{*}{ rs72749747 } & G 98,3\% & G 98,1\% \\
\hline & & A $1,7 \%$ & A $1,9 \%$ \\
\hline
\end{tabular}

${ }^{*} p>0,05$

_. Ausência de base nitrogenada

Tabela 9. Frequência genotípica dos polimorfismos identificados na região promotora do gene KISS1 em pacientes com PPC e controles

\begin{tabular}{|c|c|c|c|}
\hline Nucleotídeo & Ref seq & PPC & Controles \\
\hline \multirow{2}{*}{-936 delC } & & C/C 81,5\% & C/C 82,9\% \\
\hline & & $C l \_18,5 \%$ & $\mathrm{Cl} \_17,1 \%$ \\
\hline \multirow{3}{*}{$-454 C>T$} & \multirow{3}{*}{ rs3924585 } & C/C 84,8\% & C/C 85,6\% \\
\hline & & $\mathrm{C} / \mathrm{T} 14,1 \%$ & $\mathrm{C} / \mathrm{T} 14,4 \%$ \\
\hline & & $\mathrm{T} / \mathrm{T}$ 1,1\% & 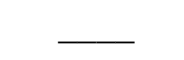 \\
\hline \multirow{3}{*}{$-415 G>A$} & \multirow{3}{*}{ rs3924586 } & G/G 33,7\% & G/G $17,3 \%$ \\
\hline & & G/A 32,3\% & G/A 55,8\% \\
\hline & & A/A 33,7\% & A/A $26,9 \%$ \\
\hline \multirow{2}{*}{$-353 T>C$} & \multirow{2}{*}{ rs56095702 } & T/T 91,3\% & $\mathrm{T} / \mathrm{T} 88,5 \%$ \\
\hline & & T/C 8,7\% & T/C 11,5\% \\
\hline \multirow{2}{*}{$-60 G>A$} & \multirow{2}{*}{ rs 72749747} & G/G 96,7\% & G/G 96,1\% \\
\hline & & G/A 3,3\% & G/A 3,9\% \\
\hline
\end{tabular}

${ }^{*} p>0,05$

_.: Ausência de base nitrogenada 


\subsection{Pesquisa de mutações e polimorfismos no gene KISS1R}

A partir do estudo de 107 pacientes com PPC, identificamos seis variantes polimórficas na região codificadora do gene KISS1R: quatro SNPS sinônimos; c.185A>G, c.776A>C, c.848C>T, c.1316G>A e dois SNPs não sinônimos; c.726G>A e c.1252T>A; e uma variante alélica na região não codificadora: c.39C>T (Figura 9). Todos os polimorfismos encontrados haviam sido previamente descritos (ref seq CONTIG NT-011255.14 www.ncbi.nlm.nih.gov/SNP). (Tabelas 10 e 11). Identificamos apenas uma mutação p.R386P, anteriormente descrita por Teles et al. [60] , a partir da análise de 107 crianças com PPC. A prevalência para essa variante foi 0,93\% (1/107). Um total de 100 controles foi selecionado para o estudo do gene KISS1R.
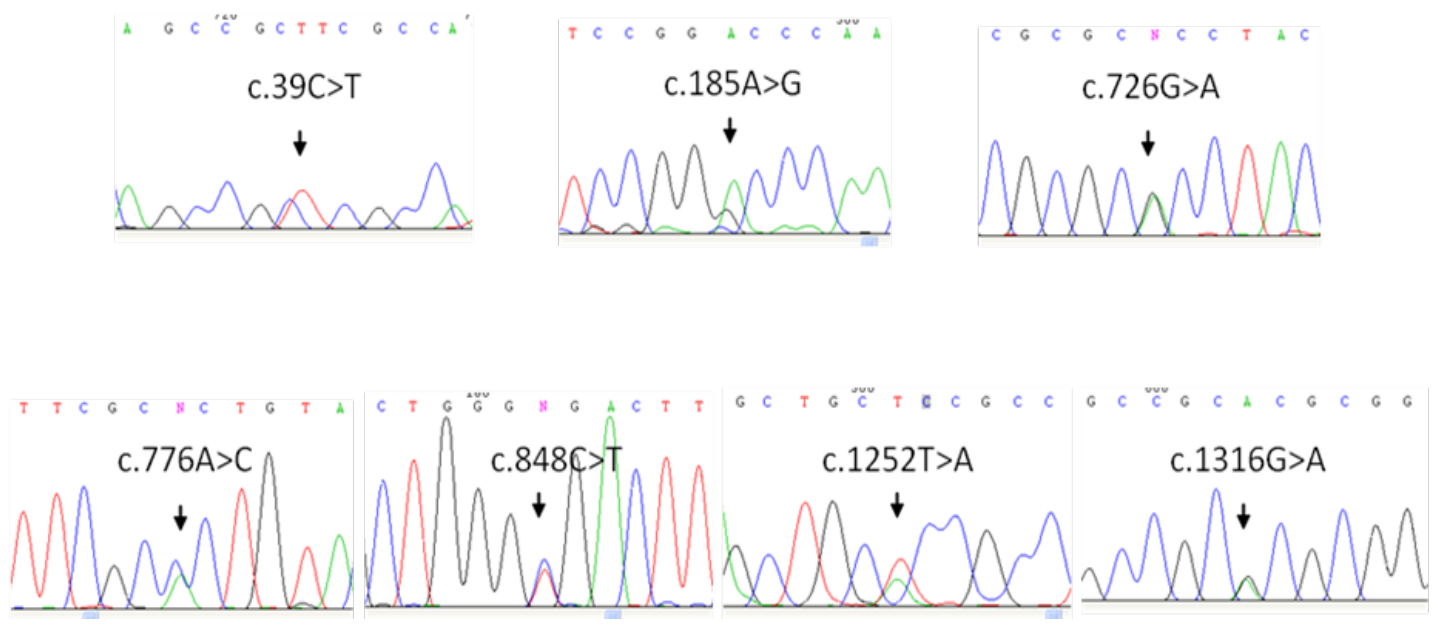

Figura 9. Eletroferograma mostrando as variantes polimórficas identificadas nos cinco exons do gene $K I S S 1 R$, incluindo regiões codificadoras e não traduzidas 
Tabela 10. Frequência alélica dos polimorfismos identificados no gene KISS1R em pacientes com PPC

\begin{tabular}{|c|c|c|c|c|c|}
\hline EXON & Nucleotídeo & Ref seq & Proteína & $\begin{array}{c}\text { PPC } \\
(n=107)\end{array}$ & $\begin{array}{c}\text { Controles } \\
(n=100)\end{array}$ \\
\hline 1 & c. $39 \mathrm{C}>\mathrm{T}$ & rs3810423 & 5'UTR & $\begin{array}{c}\text { C } 98,1 \% \\
\text { т } 1,9 \%\end{array}$ & $\begin{array}{c}\text { C } 97 \% \\
\text { T } 3 \%\end{array}$ \\
\hline 1 & c. $185 A>G$ & rs10407968 & p.G8G & $\begin{array}{l}\text { A } 83,3 \% \\
\text { G } 16,7 \%\end{array}$ & $\begin{array}{l}\text { A 84\% } \\
\text { G 16\% }\end{array}$ \\
\hline 4 & c. $726 \mathrm{G}>\mathrm{A}$ & rs73507527 & p.A189T & $\begin{array}{c}\text { G } 96,7 \% \\
\text { A } 3,3 \%\end{array}$ & $\begin{array}{c}\text { G } 96,2 \% \\
\text { A } 3,8 \%\end{array}$ \\
\hline 4 & c. $776 A>C$ & rs8111938 & p.A205A & $\begin{array}{l}\text { A 99\% } \\
\text { C 1\% }\end{array}$ & $\begin{array}{c}\text { A } 98,5 \% \\
\text { C } 1,5 \%\end{array}$ \\
\hline 4 & c. $848 \mathrm{C}>\mathrm{T}$ & rs115335009 & p.R229R & $\begin{array}{c}\text { C } 98,6 \% \\
\text { T } 1,4 \%\end{array}$ & $\begin{array}{l}\text { C 98\% } \\
\text { T 2\% }\end{array}$ \\
\hline 5 & c. $1252 T>A$ & rs350132 & p.H364L & $\begin{array}{l}\text { T } 54,2 \% \\
\text { A } 45,8 \%\end{array}$ & $\begin{array}{l}\text { T } 52,2 \% \\
\text { A } 47,8 \%\end{array}$ \\
\hline 5 & c. $1316 \mathrm{G}>\mathrm{A}$ & rs3746147 & p.A385A & $\begin{array}{c}\text { G } 99,5 \% \\
\text { A } 0,5 \%\end{array}$ & $\begin{array}{c}\text { G } 99,6 \% \\
\text { A } 0,4 \%\end{array}$ \\
\hline
\end{tabular}

$*_{p}>0,05$

Tabela 11. Frequência genotípica dos polimorfismos identificados no gene KISS1R em pacientes com PPC

\begin{tabular}{|c|c|c|c|c|c|}
\hline EXON & Nucleotídeo & Ref seq & Proteína & $\begin{array}{c}\text { PPC } \\
(n=107)\end{array}$ & $\begin{array}{c}\text { Controles } \\
(n=100)\end{array}$ \\
\hline 1 & c. $39 \mathrm{C}>\mathrm{T}$ & rs3810423 & 5'UTR & $\begin{array}{c}\text { C/C } 96,3 \% \\
\text { C/T 3,7\% }\end{array}$ & $\begin{array}{c}\text { C/C 94\% } \\
\text { C/T 6\% }\end{array}$ \\
\hline 1 & c. $185 A>G$ & rs10407968 & p.G8G & $\begin{array}{c}\text { A/A } 67,6 \% \\
\text { A/G 31,5\% } \\
\text { G/G 0,9\% }\end{array}$ & $\begin{array}{c}\text { A/A } 69,4 \% \\
\text { A/G 29,3\% } \\
\text { G/G 1,3\% }\end{array}$ \\
\hline 4 & c. $726 \mathrm{G}>\mathrm{A}$ & rs73507527 & p.A189T & $\begin{array}{c}\text { G/G 93,5\% } \\
\text { G/A } 6,5 \%\end{array}$ & $\begin{array}{c}\text { G/G } 92,4 \% \\
\text { G/A } 7,6 \%\end{array}$ \\
\hline 4 & c. $776 A>C$ & rs8111938 & p.A205A & $\begin{array}{c}\text { A/A } 98,1 \% \\
\text { A/C } 1,9 \%\end{array}$ & $\begin{array}{c}\text { A/A } 97 \% \\
\text { A/C } 3 \%\end{array}$ \\
\hline 4 & c. $848 \mathrm{C}>\mathrm{T}$ & rs115335009 & p.R229R & $\begin{array}{c}\text { C/C } 97,2 \% \\
\text { C/T 2,8\% }\end{array}$ & $\begin{array}{c}\text { C/C } 96,1 \% \\
\text { C/T 3,9\% }\end{array}$ \\
\hline 5 & c. $1252 T>A$ & rs350132 & p.H364L & $\begin{array}{l}\text { T/T 36,1\% } \\
\text { T/A 36,3\% } \\
\text { A/A 30,6\% }\end{array}$ & $\begin{array}{c}\text { T/T 32,7\% } \\
\text { T/A 39\% } \\
\text { A/A 28,3\% }\end{array}$ \\
\hline 5 & c. $1316 G>A$ & rs3746147 & p.A385A & $\begin{array}{c}\text { G/G 99\% } \\
\text { G/A } 1 \%\end{array}$ & $\begin{array}{c}\text { G/G 99,3\% } \\
\text { G/A 0,7\% }\end{array}$ \\
\hline
\end{tabular}




\subsection{Pesquisa de mutações e polimorfismos no gene LIN28B}

O estudo dos quatro exons do gene LIN28B em 79 crianças com PPC, revelou uma transição de uma adenina por uma guanina em heterozigose na posição 799 do cDNA no exon 4 do gene LIN28B (c.799A>G) (Figura 10), resultando na substituição de uma histidina por uma arginina na posição 199, localizada na região carboxi-terminal. A variante p.H199R foi identificada em uma menina com PPC esporádica. Seu pai era portador da mesma variante, em heterozigose, apesar de apresentar um histórico de desenvolvimento puberal normal. Em contraste sua mãe não apresentou a mesma variante e sua irmã não foi disponível para estudo molecular. A variante c.799A >G estava ausente nos 400 alelos dos controles analisados (Figura 10).

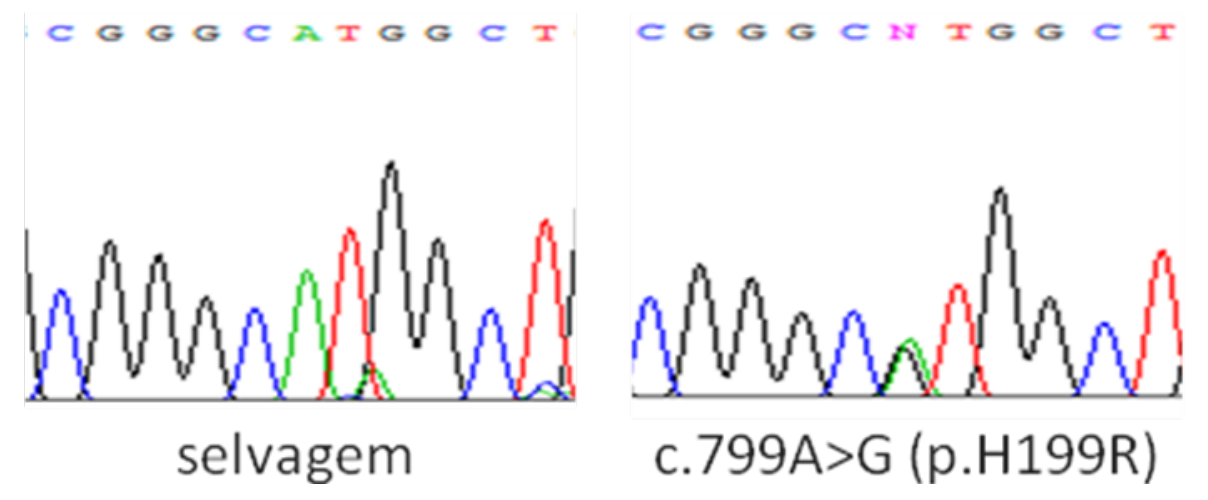

Figura 10. Eletroferograma mostrando a substituição de uma adenina por uma guanina em heterozigose no exon 4 do gene $L I N 28 B$ (c.799A $>G$ ), em comparação com uma sequência normal 
Uma variante alélica no íntron 2 do gene $L I N 28 B$ foi identificada numa menina com PPC, consistindo de uma transição de timina por citosina em heterozigose na posição IVS2-118 (Figura 11). Entretanto, a análise computacional utilizando o software NetGene2 demonstrou que a variante alélica IVS2-118C>T não altera o sítio de splicing no RNA maduro.

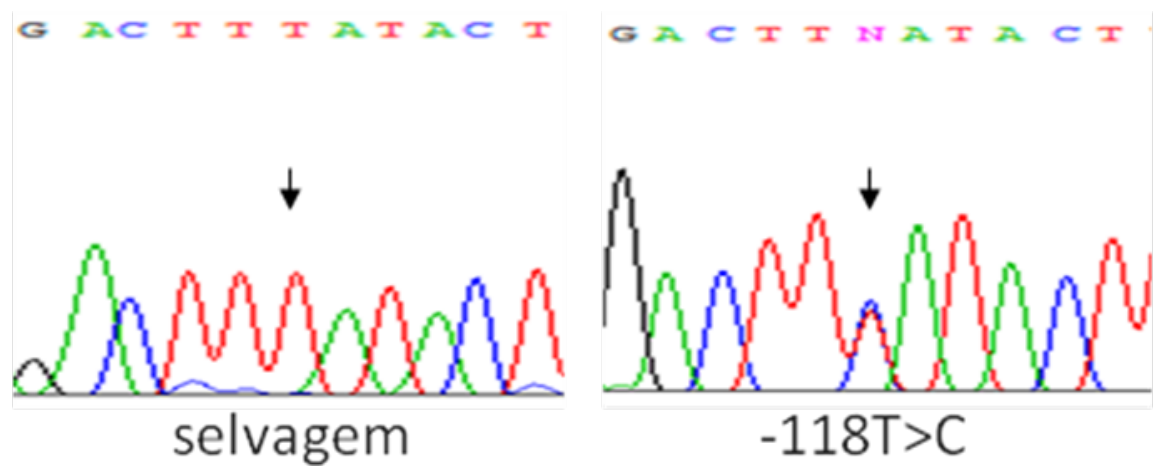

Figura 11. Eletroferograma mostrando a substituição de uma timina por uma citosina em heterozigose no íntron 2 do gene LIN28B (IVS2-118T>C), em comparação com uma sequência normal

\subsubsection{Apresentação clínica da paciente portadora da variante p.H199R do LIN28B}

Uma menina de 5,3 anos de idade foi avaliada em nosso ambulatório com queixa de telarca aos 4 anos de idade (Paciente número 8 da Tabela 1). $\mathrm{Na}$ história pregressa, apresentava relato de parto normal a termo, sem intercorrências. Negava exposição a esteróides sexuais. A paciente apresentou uma convulsão isolada e anemia tratada com sulfato ferroso. Nos antecedentes familiares, a mãe da paciente apresentava uma estatura de 158 cm e história de menarca aos 13 anos de idade e a irmã do propósito uma estatura de $162 \mathrm{~cm}$, telarca e menarca aos nove e dez anos de idade, 
respectivamente. O exame clínico evidenciou mamas direita e esquerda nos estádios puberal Tanner 3 e 2, respectivamente, pelos pubianos Tanner 1 , peso: $19,6 \mathrm{~kg}$, altura $116,5 \mathrm{~cm}$, com Z score :1,3, correspondendo a uma IE de seis anos e três meses. A IO era de seis anos e dez meses. Sinais adicionais de puberdade, como acne, pêlos axilares e sangramento vaginal estavam ausentes. No exame físico, foi constatado presença de uma mancha café com leite no abdome. Os exames complementares mostraram: FSH basal (IFMA): 2,1 UI/L, LH basal (IFMA): $<0,6 \mathrm{UI} / \mathrm{L}$, estradiol: $<13 \mathrm{ng} / \mathrm{dL}$ e LH pós- estímulo: 17 UI/L (IFMA); ultra-sonografia pélvica demonstrou ovários direito e esquerdo com volumes de $1,18 \mathrm{~cm}^{3}$, sem cistos e útero com volume de $1,16 \mathrm{~cm}^{3}$; RM do sistema nervoso central mostrou um ligeiro aumento na hipófise. Tratamento com análogo de GnRH (acetato de leuprolida $3,75 \mathrm{mg}$ a cada 28 dias) foi instituído por cinco anos e 9 meses (dos cinco anos e três meses aos onze anos), com resposta clínica adequada.

$\mathrm{Na}$ última consulta, a paciente estava com 16 anos e cinco meses, estatura de $156 \mathrm{~cm}$ (estatura alvo= 158,5 cm). Menarca espontânea ocorreu aos 12 anos de idade. O resumo da apresentação clínica da paciente portadora da variante p.H199R pode ser visto na Tabela 12. 
Tabela 12. Características clínicas da paciente portadora da variante p.H199R no gene LIN28B

\begin{tabular}{ll}
\hline sexo & feminino \\
Início de puberdade & $4 \mathrm{a}$ \\
Início de seguimento & $5 \mathrm{a} 3 \mathrm{~m}$ \\
& estádio puberal: T3 mama direita; \\
& T2 mama esquerda \\
& IO: $6 \mathrm{a} 10 \mathrm{~m}$ \\
& $\mathrm{E}_{2}:<13 \mathrm{ng} / \mathrm{dL}$ \\
& LH (IFMA): $<0,6 \mathrm{UI} / \mathrm{L}$ \\
Exames & $\mathrm{FSH}(\mathrm{IFMA}): 2,1 \mathrm{UI} / \mathrm{L}$ \\
& LH pós GnRH: $17 \mathrm{UI} / \mathrm{L}$ \\
& Hipófise ligeiramente aumentada- \\
& normal \\
RM & Acetato de leuprolida depot \\
\end{tabular}

RM: ressonância magnética

\subsection{Estudos funcionais}

O estudo consistiu inicialmente em avaliar a expressão dos cDNAs do LIN28B selvagem e da variante H199R, e na purificação da proteína Flag a partir de células HEK293 transfectadas com os vetores contendo as sequências selvagem (pFLAG-CMV2-LIN28B) ou mutante (pFLAG-CMV2LIN28B H199R). Posteriormente, analisamos o imunoprecipitado (Flag+proteína) por Western Blotting. Essa análise revelou que não houve uma diferença significativa na expressão da proteína LIN28B selvagem e mutante (Figura12). Entretanto, nos estudos de Western Blotting, foi observada a presença de uma banda com uma atividade migratória mais lenta na proteína LIN28B selvagem, utilizando-se tanto um anticorpo 
específico para Flag, quanto um anticorpo específico para o LIN28B (dados não disponíveis). De fato, essa banda não foi identificada na migração da proteína da variante p.H199R (Figura12).

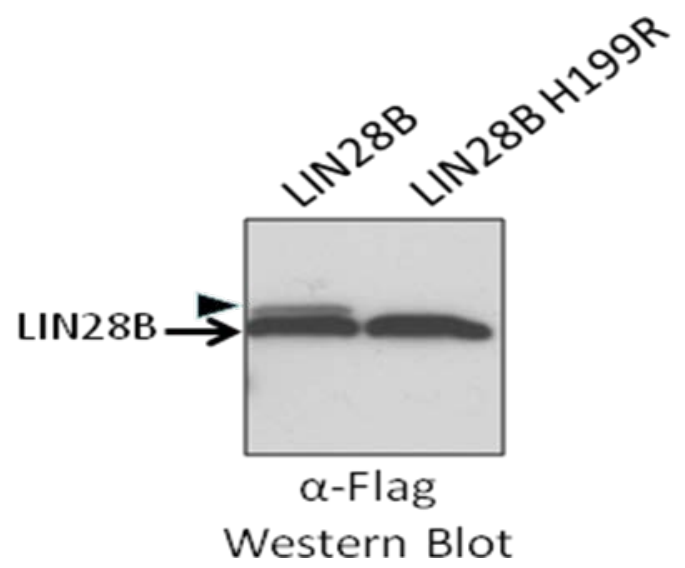

Figura 12. Análise por Western Blotting das proteínas LIN28B e LIN28B H199R imunopurificadas com anticorpo anti-Flag

A afinidade de ligação das proteínas LIN28B selvagem e LIN28B H199R foi avaliada por EMSA, utilizando-se um RNA pré-let-7 sintético marcado radioativamente. Essa análise revelou que ambas proteínas exibiram afinidades similares de ligação ao RNA pré-let-7 (Figura13).

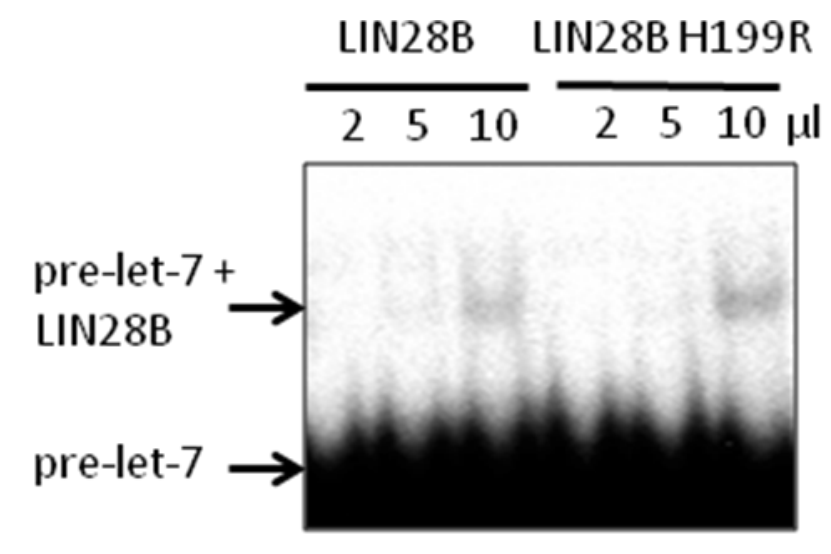

EMSA

Figura 13. EMSA realizado com pré-let-7 e quantidades crescentes de proteínas LIN28B e LIN28B H199R imunopurificadas com anticorpo anti-Flag 
Avaliamos também a capacidade dessas proteínas em inibir a expressão de let-7. Para isso, células HEK293 foram transfectadas com plasmídeos expressando pri-let-7g, juntamente com plasmídeos expressando LIN28B, LIN28B H199R ou controle. Analisamos os níveis de expressão de miRNA maduros de let-7 por PCR em Tempo Real. Ambas proteínas levaram à uma inibição no acúmulo de let-7g maduro, e apresentaram a mesma capacidade de bloquear a biogênese de let-7g maduro (Figura 14).

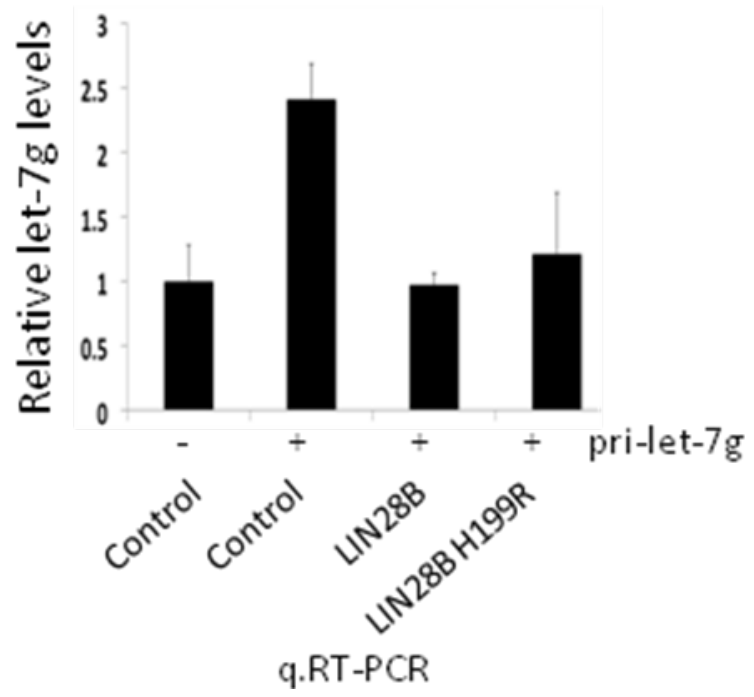

Figura 14. Análise por PCR em Tempo Real da expressão de let-7g maduro em células HEK293

Finalmente, comparamos a capacidade de LIN28B selvagem e LIN128B H199R de inibir o let-7 no ensaio de luciferase, caracterizado por um plasmídeo contendo o gene repórter da luciferase e sítios funcionais de ligação ao let-7 na região 3'UTR. A expressão da luciferase foi reprimida 
pelo let-7 nesse vetor, como esperado (Figura 15). Utilizando esse sistema, observamos que a co- expressão de LIN28B e let-7 levou ao alívio na repressão da luciferase e consequentemente, estimulou a expressão desse gene (Figura 15). Além disso, a expressão da proteína LIN28B H199R apresentou a mesma capacidade de aliviar a repressão da luciferase que a proteína selvagem (Figura 15). Esses dados em conjunto sugeriram que a variante LIN28B H199R não altera a capacidade de reprimir a expressão de let-7.

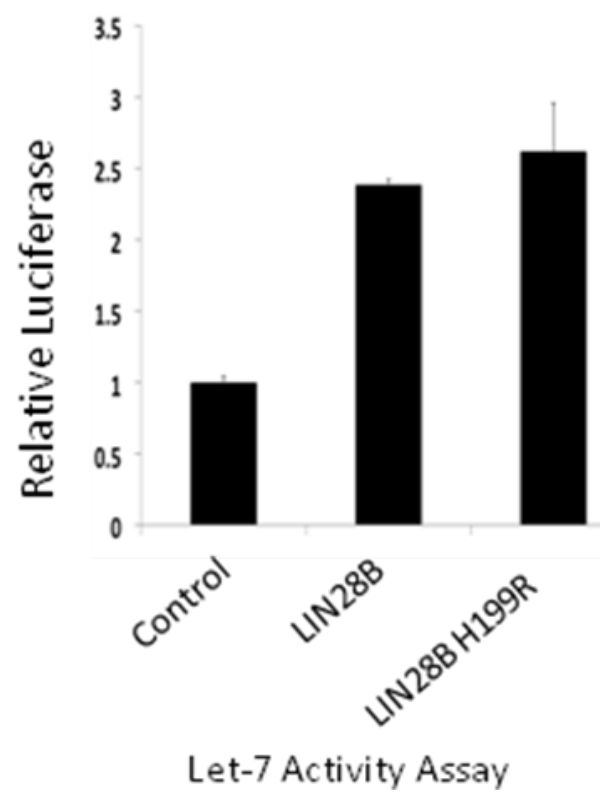

Figura 15. Ensaio da atividade de luciferase através de um gene repórter responsivo a let-7. Células Hela foram co-transfectadas com plasmídeos expressando pri-let-7g, juntamente com plasmídeos expressando LIN28B, LIN28B H199R ou controle 


\section{DISCUSSÃO}


A identificação de mutações inativadoras e deleções no gene KISS1R em humanos com ausência de desenvolvimento puberal foi a primeira evidência de que o sistema kisspeptina-KISS1R é essencial para a ativação da secreção do GnRH e para o início da puberdade [2, 27, 33].

Em 2007, um estudo de rastreamento para polimorfismos no gene KISS1R em 272 meninas chinesas com PPC identificou apenas uma mutação em uma menina (p.P196H), localizada na segunda alça extracelular do receptor [94]. Nenhum estudo foi realizado para avaliar se esse receptor mutado apresenta um ganho de função [94]. Por outro lado, o mesmo estudo identificou um polimorfismo prevalente no gene KISS1 (p.P110T), o qual se mostrou estatisticamente associado com PPC, entretanto, estudos funcionais ainda não foram realizados para confirmar se essa substituição de aminoácidos leva a um aumento na capacidade de ativação do KISS1R [95].

Teles et al. [60], e Silveira et al. [61] identificaram mutações nos genes KISS1R e KISS1, que foram implicadas com o desenvolvimento de PPC em crianças brasileiras. Teles et al. [60] estudaram o gene KISS1R em 53 crianças com PPC idiopática e identificaram a mutação p.R386P numa menina. Estudos in vitro revelaram uma redução significante no índice de dessensibilização do KISS1R mutante, levando a um ganho de função da via de sinalização intracelular em resposta a kisspeptina. Recentemente, Bianco et al. [96] elucidaram o mecanismo de dessensibilização do receptor mutante 
KISS1R R386P pela observação que esse receptor permanece na membrana da superfície celular por tempos mais prolongados, devido a uma diminuição na sua taxa de degradação.

Silveira et al. [61] estudaram o gene KISS1 em 83 crianças com PPC idiopática e identificaram a mutação p.P74S num menino que apresentou desenvolvimento puberal extremamente precoce (12 meses de idade), com valores muito elevados de testosterona e gonadotropinas basais, associados a RM normal do SNC. Estudos in vitro revelaram que a mutação p.P74S possui uma maior resistência a degradação, devido a sua menor taxa de degradação, podendo levar ao aumento na disponibilidade de kisspeptina e consequentemente influenciar o desenvolvimento do fenótipo de puberdade precoce nesse menino. Uma segunda variante, p.H90D, foi identificada numa menina com PPC e estudos in vitro com essa variante não revelaram alterações na capacidade de ligação ou ativação do KISS1R e na resistência a degradação.

É notável, que as variantes p.P196H e p.P110T identificadas nos estudos de Luan et al. [94, 95] não foram encontradas no grupo de crianças sul-americanas com PPC [60, 61]. Além disso, as mutações ativadoras p.R386P e p.P74S, também não foram identificadas na casuística chinesa, indicando que essas variantes são provavelmente específicas para cada população.

Recentemente, pesquisadores da USP de Ribeirão Preto também identificaram uma mutação na região amino-terminal do KISS1R (p.P37S) em uma menina com PPC idiopática, num grupo de 104 crianças, entretanto, 
o estudo funcional desta nova mutação ainda não foi publicado [97].

resumo das mutações ou polimorfismos identificados nos genes KISS1 e KISS1R em crianças com PPC pode ser encontrado na Tabela 13.

Tabela 13. Resumo das mutações ou polimorfismos do tipo missense identificados nos genes KISS1R e KISS1 em crianças com PPC

\begin{tabular}{cccccc}
\hline Gene & $\begin{array}{c}\text { Mutação ou } \\
\text { polimorfismo }\end{array}$ & $\begin{array}{c}\text { Número de } \\
\text { pacientes com a } \\
\text { variante } \\
\text { (prevalência) }\end{array}$ & $\begin{array}{c}\text { Número de } \\
\text { controles com } \\
\text { a variante } \\
\text { (prevalência) }\end{array}$ & $\begin{array}{c}\text { Estudo } \\
\text { Funcional }\end{array}$ & Referência \\
\hline $\begin{array}{c}\text { KISS1 } \\
\text { R }\end{array}$ & p.P196H & $1(0,36 \%)$ & 0 & Não realizado & $(94)$ \\
\hline $\begin{array}{c}\text { KISS1 } \\
\text { R }\end{array}$ & p.R386P & $1(0,93 \%)$ & 0 & $\begin{array}{c}\text { Redução no } \\
\text { índice de } \\
\text { dessensibilização }\end{array}$ & $\begin{array}{c}\text { dissertação } \\
\text { atual }\end{array}$ \\
\hline KISS1 & p.P37S & $1(0,96 \%)$ & 0 & Não disponível & $(97)$ \\
\hline KISS1 & p.P110T & $255(94 \%)$ & $16(5,7 \%)$ & Não realizado & (95) \\
\hline KISS1 & p.P74S & $1(1,1 \%)$ & 0 & $\begin{array}{c}\text { Aumento na } \\
\text { resitência à } \\
\text { degradação }\end{array}$ & $\begin{array}{c}\text { dissertação } \\
\text { atual }\end{array}$ \\
\hline KISS1 & p.H90D & $4(4,4 \%)$ & $\begin{array}{c}\text { Nenhuma } \\
\text { alteração na } \\
\text { ligação ou } \\
\text { ativação do } \\
\text { GPR54 }\end{array}$ & $\begin{array}{c}\text { dissertação } \\
\text { atual }\end{array}$ \\
\hline
\end{tabular}

Devido a importância do sistema kisspeptina-KISS1R na regulação da secreção de $\mathrm{GnRH}$, e consequentemente no desenvolvimento puberal, é possível que novas alterações nesses genes possam contribuir para o desenvolvimento de PPC. Como um dos objetivos do nosso projeto foi determinar a prevalência de mutações conhecidas ou novas nos genes KISS1 e KISS1R em crianças com PPC idiopática, nós agregamos os resultados obtidos e publicados anteriormente $[60,61]$ com os resultados 
deste trabalho. Nosso grupo identificou apenas uma mutação ativadora no gene KISS1R (p.R386P) a partir do estudo de 107 crianças com PPC e duas mutações no gene KISS1 em cinco pacientes (um deles com a p.P74S e os demais com a p.H90D) a partir de 91 crianças com PPC. As prevalências dessas mutações foram: 0,93\% (1/107) para o gene KISS1R e 5,5\% (5/91), para o KISS1. Esses dados sugerem que as mutações ativadoras p.R386P do KISS1R e p.P74S da kisspeptina apresentaram prevalência muito baixa em um grupo de crianças com puberdade precoce central.

\subsection{Variante p.H90D no gene KISS1}

A variante $c .422 C>G$ (p.H90D), foi identificada em quatro meninas brasileiras com PPC. Apenas duas destas meninas apresentaram essa variante em homozigose, e suas mães, as quais apresentaram desenvolvimento puberal normal, também eram portadoras da mesma variante, sendo uma delas em homozigose e a outra em heterozigose. Nenhum dos familiares das duas meninas que apresentaram a variante em heterozigose estavam disponíveis para o estudo molecular. Essa variante está localizada no exon 3 do gene KISS1, levando a substituição do aminoácido histidina polar não conservada por um ácido aspártico apolar na posição 90 da kisspeptina-1 (p.H90D), correspondendo à região aminoterminal da kisspeptina-54 (Figura 5). 
Essa variante estava ausente em 200 controles brasileiros, sugerindo que essa alteração não é um polimorfismo. Uma variante alélica é considerada um polimorfismo gênico se está presente em mais de $1 \%$ de uma determinada população. Esse conceito é baseado na frequência populacional e não leva em conta os efeitos patogênicos de uma variante [98].

Embora a variante p.H90D estava ausente em controles brasileiros, ela tem sido raramente identificada em heterozigose em alguns indivíduos normais e hipogonádicos em populações americana e francesa, respectivamente [99]. Além disso, estudos in vitro com a variante p.H90D não revelaram alterações na capacidade de ligação ou ativação do KISS1R e na resistência a degradação [61].

\subsection{Polimorfismos no gene KISS1}

O KISS1 é um gene polimórfico com variações nucleotídicas descritas nas regiões promotora, codificadora e não codificadora. Na população estudada, identificamos dois SNPs na região não codificadora e quatro SNPs não sinônimos na região codificadora, previamente descritos, porém apenas um deles localizado dentro da sequência de kisspeptina-54 (p.P81R). Os SNPs identificados não diferiram significantemente em frequência nos grupos com PPC e controles, sugerindo uma ausência de correlação desses SNPs, pelo menos em um caráter individual, com a 
regulação do início da puberdade. No presente estudo, a associação de haplótipos específicos com os fenótipos de PPC não foi avaliada. No entanto, Nicolas de Roux (dados não publicados) mostrou um estudo sobre haplótipos envolvendo SNPs da região 3' não traduzida em 25 casos de PPC. Um dos haplótipos apresentou correlação positiva com o fenótipo de PPC, reforçando um papel potencial para a região 3' não traduzida na regulação da transcrição do KISS1 e, consequentemente, no início da puberdade. Uma sequência conservada de 1 kb na região 5' a montante do sítio de início de transcrição do KISS1 foi analisada neste estudo nos grupos PPC e controle. Essa região tem despertado interesse crescente devido à presença de sequências consenso de ligação de fatores de transcrição conhecidos, alguns desses associados à regulação da transcrição do KISS1 em estudos prévios, como TTF1 e o Sp1 [100, 101]. O estrógeno exerce um papel regulatório na transcrição hipotalâmica do KISS1 por meio do ER $\alpha$, porém o mecanismo molecular ainda não é bem estabelecido. Foi sugerido que essa regulação ocorre através da interação de ER $\alpha$ e Sp1 com regiões ricas em GC no promotor do KISS1 [102].

Identificamos cinco SNPs na região promotora do KISS1. O SNP 60G>A encontra-se em uma sequência consenso potencial de ligação do Sp1, entretanto, a freqüência genotípica e alélica deste e dos demais SNPs identificados não foram estatisticamente diferentes entre crianças com PPC e controles (Tabelas 8 e 9). 


\subsection{Variante p.H199R no gene LIN28B}

A variante p.H199R foi identificada em heterozigose em uma menina brasileira com PPC idiopática. Essa variante está localizada no exon 4 do gene $L I N 28 B$, levando a substituição de uma histidina por uma arginina na posição 199 da região carboxi-terminal. O pai da paciente, que apresentou desenvolvimento puberal normal, era portador da mesma variante em heterozigose. Tanto histidina, quanto arginina são aminoácidos hidrofílicos e polares positivos.

A análise comparativa da sequência de aminoácidos de LIN28B revelou que a histidina na posição 199 é conservada entre os mamíferos (Tabela 14).

Tabela 14. Análise comparativa da sequência de aminoácidos de LIN28B entre diferentes espécies de mamíferos

\begin{tabular}{|l|l|ll|}
\hline V-G-G-G- H & -G-C-T-S-P & Homo sapiens \\
V-G-G-G- H & -G-C-T-S-P & Pan troglodytes \\
V-G-G-G- H & -G-C-T-S-P & Gorilla gorilla \\
V-G-G-G- H & -G-C-T-S-P & Macaca mulatta \\
V-G-G-G- H & -S-C-T-S-- & Bos taurus \\
V-G-G-G- H & -G-C-T-V-L & Mus musculus \\
V-G-G-G- H & -G-C-T-V-P & Rattus Novergicus
\end{tabular}

Entre os genes que são regulados pelo LIN28B está o let-7, um membro da família dos miRNAs let-7. Esses miRNAs são conhecidos por controlarem o tempo de desenvolvimento de C. elegans e atuarem como 
supressores tumorais [69]. A expressão de let-7 é temporalmente regulada, exibindo uma ausência de expressão nas fases L1 e L2 do desenvolvimento larval no C. elegans, baixa expressão na L3 e alta expressão no começo de L4 e adulto [103]. Mutações recessivas que geraram a perda de atividade do gene let-7 causaram a reiteração de destinos celulares específicos de larvas durante o estágio adulto, enquanto que mutações dominantes que levaram a um ganho de função desse gene acarretaram numa precoce expressão de destinos celulares específicos de adultos durante os estágios larvais no $C$. elegans [103]. A transativação do gene LIN28B humano pelo oncongene c-Myc pode reprimir a expressão de miRNAs da família let-7 numa linhagem de células B de linfoma [104]. Estudos de imunoprecipitação de cromatina (ChIP) revelaram que c-Myc se liga a sequências conservadas (E)-box enhancer localizadas dentro do primeiro íntron do gene LIN28B, resultando assim no aumento da expressão gênica de LIN28B e conseqüente diminuição dos níveis de miRNAs da família let-7 [104]. Let-7 também é capaz de regular a expressão de LIN28B em células Hela, por meio de dois elementos de reconhecimento de miRNA (miRNA-recognition elements, MREs) presentes na região 3 'UTR do mRNA de LIN28B [70].

O miRNA-let-7 também apresenta sequências complementares as regiões 3'UTR de outros genes heterocrônicos, entre eles: lin-14, lin-41, lin-42 e daf-12, indicando que a expressão desses genes podem ser também diretamente controlada pelo let-7 [103]. Por outro lado, Lin28a e Lin28b bloqueiam a maturação do miRNA-let-7 em células-tronco embrionárias e em células de carcinoma embrionário indiferenciado [78, 79]. 
Estudos recentes observaram que a presença de uma citosina na região terminal da alça do pré-let-7 é de fundamental importância para a ligação do Lin28a, uma vez que a troca de citosina por adenina resultou numa severa redução dessa ligação. Além disso, Lin28a com mutações nos domínios CSD ou ZFD não foi capaz de se ligar ao pré-let-7 e inibir o seu processamento [93].

Uma vez que LIN28B regula o mRNA let-7, mutações inativadoras em LIN28B poderiam afetar a repressão de mRNA let-7 e consequentemente estimular o desenvolvimento puberal em humanos. Entre os mecanismos potenciais de inativação da variante p.H199R estão: (1) redução da concentração de transcritos de $L I N 28 B$, devido a uma diminuição na transcrição e/ou aumento na degradação; (2) redução da concentração protéica, devido a uma diminuição na produção; (3) redução da capacidade de ligação ao pré-let-7 e (4) redução do recrutamento da TUTase (Zcchc11).

De fato, mutações deletérias em lin-28 levam a um rápido desenvolvimento puberal em larvas de C. elegans [69]. Além dos quatro diferentes estudos de associação ampla do genoma (GWAS) que estabeleceram que marcadores genéticos próximos ou dentro do gene LIN28B estavam relacionados com o tempo de menarca em meninas [65-68], outros artigos demonstraram uma relação de LIN28B com a exposição de andrógenos no período pré-natal e puberdade [105, 106].

De fato, a razão entre o comprimento do segundo (indicador) e quarto (anelar) dedos de um indivíduo (2D:4D) é normalmente usado como um biomarcador retrospectivo não invasivo para exposição de andrógenos no 
período pré-natal [105]. Com o intuito de identificar variantes genéticas que estivessem relacionadas com 2D:4D, Medland et al. [107] realizaram um GWAS em 2889 crianças de dois estudos populacionais. A meta-análise dos estudos identificou um único SNP no íntron 2 do gene LIN28B que estava fortemente associado com 2D:4D (rs 314277: $p=4,1 \times 10^{-8}$ ) e cada cópia do alelo A do SNP foi associado com aumento de 0,6 anos na razão 2D:4D. Esse gene é altamente expresso em testículos, placenta e fígado fetal [70], sugerindo que LIN28B poderia influenciar na razão 2D:4D no começo do desenvolvimento. Recentemente, Zhu et al. [108] observaram que camundongos transgênicos que superexpressam Lin28a apresentam um atraso na puberdade. As linhagens de camundongos CD-1 e C57BL/6 exibiram um atraso de 2,24 e 2,18 dias na abertura vaginal, respectivamente. No dia 26 pós-natal, o peso dos ovários e útero foi maior em camundongos selvagem, além disso, esses camundongos tiveram o primeiro ciclo estral 4,5 dias mais cedo do que os transgênicos [106].

Com o objetivo de avaliar a hipótese de que a variante p.H199R poderia afetar a repressão de mRNA let-7 e consequentemente estimular o desenvolvimento puberal na menina com PPC, planejamos um estudo funcional em colaboração com o professor Richard Gregory do Department of Biological Chemistry and Molecular Pharmacology, Harvard Medical School, Boston, que consistiu na análise comparativa da regulação da expressão de mRNA let-7 pelo LIN28B selvagem e mutante in vitro. Nesse estudo, observamos que a proteína LIN28B mutante mostrou uma mesma capacidade de inibir a expressão do miRNA-let-7 que a proteína 
LIN28B selvagem, quando expressas ectopicamente em células HEK293. De acordo com esses achados, LIN28B selvagem e mutante também não mostraram uma diferença na capacidade de ligação ao pré-let-7. Esses dados em conjunto sugerem que a proteína mutante não afeta a função de LIN28B na regulação da expressão de let-7. Além disso, a variante p.H199R não está localizada em nenhum dos domínios de ligação ao miRNA let-7, os quais têm definidas funções na repressão da tradução e estabilização de miRNAs, nos primeiros estágios de células somáticas e embriões [80, 81]. Embora esses estudos indicaram que a variante p.H199R não afeta a regulação da expressão de mRNA let-7, não pode ser descartado o fato de que LIN28B possa regular a expressão de outros genes que estejam envolvidos na regulação do tempo de puberdade em humanos. De fato, Lin28A também apresenta uma função adicional na regulação gênica no citoplasma de células embrionárias humanas, onde pode se associar diretamente a outros tipos de mRNAs [109]. Lin28A e Lin28B apresentam um diferente modelo de localização, com LIN28B sendo mais predominante no núcleo (Piskounova et al., dados não publicados). Assim, seria importante explorarmos as funções adicionais de LIN28B e avaliarmos as consequências da variante p.H199R nesse contexto. Além disso, seria interessante identificarmos as modificações pós-traducionais na proteína LIN28B mutante, as quais podem ser responsáveis pela alteração no seu modelo de migração no gel de poliacrilamida (Figura 12).

A variante p.H199R estava ausente em 200 controles brasileiros, sugerindo que essa alteração não é um polimorfismo [110]. No entanto, a 
presença da variante no pai assintomático do propósito, contraria o papel desse defeito no fenótipo de PPC. Além disso, a frequência genotípica da variante p.H199R (c.A799G) foi investigada em 1634 meninas que apresentaram desenvolvimento sexual normal, as quais foram divididas em dois grupos: idade de menarca mais precoce (<11 anos) ou tardia (>15 anos) (dados em submissão). O alelo $\mathrm{G}$ estava em baixa frequência em ambos os grupos (<1\%) e não apresentou diferença estatística significante entre os dois grupos estudados. A variante p.H199R foi também recentemente identificada como uma variante rara em menos de $1 \%$ da população estudada no "1000 genome pilot Project", o qual caracterizou as variações da sequência do genoma humano, utilizando- se diferentes GWAS com plataformas de high-throughput [111]. Em conjunto, esses dados sugerem que a variante p.H199R não é a causa do fenótipo de PPC.

O estudo do gene LIN28B em 145 crianças com atraso constitucional de crescimento e desenvolvimento puberal (RCCP) não identificou nenhuma variante alélica na região codificadora do gene, indicando que variantes alélicas nessa região são raras [112]. No entanto, recentemente, pesquisadores da USP de Ribeirão Preto identificaram quatro variantes no gene LIN28B em crianças com PPC (dados em submissão). Uma substituição de uma citosina por timina c.-11C>T em heterozigose foi identificada em dois pacientes e um controle na região promotora do gene LIN28B. Outras duas variantes também foram identificadas no íntron 2 do gene LIN28B. A primeira variante foi encontrada em um paciente, caracterizada pela deleção de dois nucleotídeos (IVS2-33_34del) em heterozigose, mas não foi identificada em 110 controles. 
A análise computacional utilizando o programa NNSplice 0,9 demonstrou que a variante alélica (IVS2-33_34del) não altera o sítio de splicing no RNA maduro. A segunda variante identificada no íntron 2, uma troca de adenina por citosina 9575731A>C em heterozigose, já havia sido previamente descrita (rs17065417) e estava presente em 18 pacientes com PPC. Finalmente, uma variante silenciosa c.519 C>T (P173P) foi identificada no exon 3 do gene LIN28B de uma menina com PPC e estava ausente em 110 controles e análises in silico sugeriram que ela não gera um sítio de splicing anormal. O resumo das mutações ou polimorfismos identificados no gene LIN28B em crianças com PPC neste trabalho e pelo grupo de Ribeirão Preto pode ser encontrado na Tabela15.

Tabela 15. Resumo das mutações ou polimorfismos identificados no gene LIN28B em crianças com PPC. * Número de pacientes e controles estudados refere-se a junção da casuística deste trabalho e do grupo de Ribeirão Preto

\begin{tabular}{ccccc}
\hline $\begin{array}{c}\text { Mutação ou } \\
\text { polimorfismo }\end{array}$ & Localização & $\begin{array}{c}\text { Número de } \\
\text { pacientes com a } \\
\text { variante } \\
\text { (prevalência) }\end{array}$ & $\begin{array}{c}\text { Número de } \\
\text { controles com a } \\
\text { variante } \\
\text { (prevalência) }\end{array}$ & Fenótipo \\
\hline C.-11C>T & $\begin{array}{c}\text { 5'UTR } \\
\text { (promotor) }\end{array}$ & $2(2 \%)$ & $1(1 \%)$ & Desconhecido \\
\hline $\begin{array}{c}\text { IVS2- } \\
\text { 33_34delCT }\end{array}$ & Íntron2 & $1(0,5 \%)$ & 0 & $\begin{array}{c}\text { Provavelmente não } \\
\text { altera sítio de } \\
\text { splicing }\end{array}$ \\
\hline $\begin{array}{c}\text { g.9575731A>C } \\
\text { (rs17065417) }\end{array}$ & Íntron2 & $18(18 \%)$ & Sob análise & $\begin{array}{c}\text { Desconhecido } \\
\text { p.P173P }\end{array}$ \\
\hline Exon3 & $1(0,5 \%)$ & 0 & $\begin{array}{c}\text { Provavelmente não } \\
\text { altera sítio de } \\
\text { splicing }\end{array}$ \\
\hline p.H199R & Exon4 & $1(0,5 \%)$ & 0 & $\begin{array}{c}\text { Não afeta a função } \\
\text { de LIN28B na } \\
\text { regulação da } \\
\text { expressoão de let-7 }\end{array}$ \\
\hline
\end{tabular}




\section{CONCLUSÕES}


- Novas mutações nos genes KISS1 e KISS1R não foram identificadas em um grupo maior de crianças com puberdade precoce central idiopática.

- As mutações ativadoras p.R386P do KISS1R e p.P74S da kisspeptina, previamente descritas em puberdade precoce central, apresentaram prevalência muito baixa $(<1 \%)$.

- Estudos de segregação familial e populacionais sugerem que a variante p.H90D da kisspetina seja um polimorfismo raro.

- Polimorfismos nos genes KISS1, KISS1R e LIN28B não foram associados ao fenótipo de puberdade precoce central idiopática.

- Identificamos uma variante rara no LIN28B (p.H199R) em uma menina com puberdade precoce central idiopática e esporádica.

- Estudos funcionais do LIN28B selvagem ou contendo a variante p.H199R mostraram capacidade semelhante de inibir o microRNA let 7, sugerindo que a variante p.H199R do LIN28B não está relacionada ao fenótipo de puberdade precoce central.

- Embora os polimorfismos do gene LIN28B foram associados com as variações temporais do início da puberdade normal, defeitos nesse gene não estão envolvidos frequentemente na patogênese molecular da PPC. 


\section{REFERÊNCIAS}


1. Palmert MR, Boepple PA. Variation in the timing of puberty: clinical spectrum and genetic investigation. J Clin Endocrinol Metab, 2001. 86(6): p. 2364-8.

2. Seminara SB, et al. The GPR54 gene as a regulator of puberty. $N$ Engl J Med, 2003. 349(17): p. 1614-27.

3. Seminara S, Crowley Jr WF. The genetics of $\mathrm{IHH}--a$ paradox. Clin Endocrinol (Oxf), 2001. 55(2): p. 159-60.

4. Grumbach MM. The neuroendocrinology of human puberty revisited. Horm Res, 2002. 57 Suppl 2: p. 2-14.

5. Kakarla N, Bradshaw KD. Disorders of pubertal development: precocious puberty. Semin Reprod Med, 2003. 21(4): p. 339-51.

6. Terasawa E, Fernandez DL. Neurobiological mechanisms of the onset of puberty in primates. Endocr Rev, 2001. 22(1): p. 111-51.

7. Plant TM, Barker-Gibb ML. Neurobiological mechanisms of puberty in higher primates. Hum Reprod Update, 2004. 10(1): p. 67-77.

8. Dhillo WS, et al. Kisspeptin-54 stimulates the hypothalamic-pituitary gonadal axis in human males. J Clin Endocrinol Metab, 2005. 90(12): p. 6609-15.

9. El Majdoubi M, et al. Neuropeptide Y: A hypothalamic brake restraining the onset of puberty in primates. Proc Natl Acad Sci U S A, 2000. 97(11): p. 6179-84.

10. Papathanasiou A, Hadjiathanasiou C. Precocious puberty. Pediatr Endocrinol Rev, 2006. 3 Suppl 1: p. 182-7. 
11. Brito VN, et al. Factors determining normal adult height in girls with gonadotropin-dependent precocious puberty treated with depot gonadotropin-releasing hormone analogs. J Clin Endocrinol Metab, 2008. 93(7): p. 2662-9.

12. Gonzalez ER. For puberty that comes too soon, new treatment highly effective. JAMA, 1982. 248(10): p. 1149-51, 1155.

13. Partsch CJ, Sippell WG. Pathogenesis and epidemiology of precocious puberty. Effects of exogenous oestrogens. Hum Reprod Update, 2001. 7(3): p. 292-302.

14. Brunner HG, Otten BJ. Precocious puberty in boys. $N$ Engl J Med, 1999. 341(23): p. 1763-5.

15. de Vries $L$, et al. Familial central precocious puberty suggests autosomal dominant inheritance. J Clin Endocrinol Metab, 2004. 89(4): p. 1794-800.

16. Kotani $\mathrm{M}$, et al. The metastasis suppressor gene KiSS-1 encodes kisspeptins, the natural ligands of the orphan $G$ protein-coupled receptor GPR54. J Biol Chem, 2001. 276(37): p. 34631-6.

17. Muir Al, et al. AXOR12, a novel human $G$ protein-coupled receptor, activated by the peptide KiSS-1. J Biol Chem, 2001. 276(31): p. 28969-75.

18. Ohtaki T, et al. Metastasis suppressor gene KiSS-1 encodes peptide ligand of a G-protein-coupled receptor. Nature, 2001. 411(6837): p. 613-7.

19. Lee $\mathrm{JH}$, et al. KiSS-1, a novel human malignant melanoma metastasissuppressor gene. J Natl Cancer Inst, 1996. 88(23): p. 1731-7.

20. Lee JH, Welch DR. Suppression of metastasis in human breast carcinoma MDA-MB-435 cells after transfection with the metastasis suppressor gene, KiSS-1. Cancer Res, 1997. 57(12): p. 2384-7. 
21. Biran J, Ben-Dor S, Levavi-Sivan B. Molecular identification and functional characterization of the kisspeptin/kisspeptin receptor system in lower vertebrates. Biol Reprod, 2008. 79(4): p. 776-86.

22. Kanda S, et al. Identification of KiSS-1 product kisspeptin and steroidsensitive sexually dimorphic kisspeptin neurons in medaka (oryzias latipes). Endocrinology, 2008. 149(5): p. 2467-76.

23. van Aerle $\mathrm{R}$, et al. Evidence for the existence of a functional Kiss1/Kiss1 receptor pathway in fish. Peptides, 2008. 29(1): p. 57-64.

24. Popa SM, Clifton DK, Steiner RA. The role of kisspeptins and GPR54 in the neuroendocrine regulation of reproduction. Annu Rev Physiol, 2008. 70: p. 213-38.

25. West A, et al. Chromosome localization and genomic structure of the KiSS1 metastasis suppressor gene (KISS1). Genomics, 1998. 54(1): p. 145-8.

26. Lee DK, et al. Discovery of a receptor related to the galanin receptors. FEBS Lett, 1999. 446(1): p. 103-7.

27. de Roux $\mathrm{N}$, et al. Hypogonadotropic hypogonadism due to loss of function of the KiSS1-derived peptide receptor GPR54. Proc Natl Acad Sci U S A, 2003. 100(19): p. 10972-6.

28. Stafford LJ, et al. Identification and characterization of mouse metastasis-suppressor KiSS1 and its G-protein-coupled receptor. Cancer Res, 2002. 62(19): p. 5399-404.

29. Castellano JM, et al. Ontogeny and mechanisms of action for the stimulatory effect of kisspeptin on gonadotropin-releasing hormone system of the rat. Mol Cell Endocrinol, 2006. 257-258: p. 75-83.

30. Castellano JM, Roa J, Luque RM, Dieguez C, Aguilar E, Pinilla L, TenaSempere M. KiSS-1/kisspeptins and the metabolics control of reproduction physiologic roles and putative physiopathological implications. Peptides, 2009. 30(1): p. 139-45. 
31. Han SK, et al. Activation of gonadotropin-releasing hormone neurons by kisspeptin as a neuroendocrine switch for the onset of puberty. J Neurosci, 2005. 25(49): p. 11349-56.

32. Navarro VM, et al. Developmental and hormonally regulated messenger ribonucleic acid expression of KiSS-1 and its putative receptor, GPR54, in rat hypothalamus and potent luteinizing hormone-releasing activity of KiSS-1 peptide. Endocrinology, 2004. 145(10): p. 4565-74.

33. Funes S, et al. The KiSS-1 receptor GPR54 is essential for the development of the murine reproductive system. Biochem Biophys Res Commun, 2003. 312(4): p. 1357-63.

34. d'Anglemont de Tassigny $X$, et al. Hypogonadotropic hypogonadism in mice lacking a functional Kiss1 gene. Proc Natl Acad Sci U S A, 2007. 104(25): p. 10714-9.

35. Lapatto R, et al. Kiss1-/- mice exhibit more variable hypogonadism than Gpr54-/- mice. Endocrinology, 2007. 148(10): p. 4927-36.

36. Gottsch ML, et al. A role for kisspeptins in the regulation of gonadotropin secretion in the mouse. Endocrinology, 2004. 145(9): p. 4073-7.

37. Messager $\mathrm{S}$, et al. Kisspeptin directly stimulates gonadotropin-releasing hormone release via G protein-coupled receptor 54. Proc Natl Acad Sci U S A, 2005. 102(5): p. 1761-6.

38. Shahab M, et al. Increased hypothalamic GPR54 signaling: a potential mechanism for initiation of puberty in primates. Proc Natl Acad Sci U S A, 2005. 102(6): p. 2129-34.

39. Matsui $\mathrm{H}$, et al. Peripheral administration of metastin induces marked gonadotropin release and ovulation in the rat. Biochem Biophys Res Commun, 2004. 320(2): p. 383-8. 
40. Clarkson J, Herbison AE. Postnatal development of kisspeptin neurons in mouse hypothalamus; sexual dimorphism and projections to gonadotropin-releasing hormone neurons. Endocrinology, 2006. 147(12): p. 5817-25.

41. Kauffman AS, et al. Sexual differentiation of Kiss1 gene expression in the brain of the rat. Endocrinology, 2007. 148(4): p. 1774-83.

42. Pompolo S, et al. Colocalization of kisspeptin and gonadotropinreleasing hormone in the ovine brain. Endocrinology, 2006. 147(2): p. 804-10.

43. Ramaswamy $S$, et al. Structural interactions between kisspeptin and $\mathrm{GnRH}$ neurons in the mediobasal hypothalamus of the male rhesus monkey (Macaca mulatta) as revealed by double immunofluorescence and confocal microscopy. Endocrinology, 2008. 149(9): p. 4387-95.

44. Seminara SB, et al. Continuous human metastin 45-54 infusion desensitizes G protein-coupled receptor 54-induced gonadotropinreleasing hormone release monitored indirectly in the juvenile male Rhesus monkey (Macaca mulatta): a finding with therapeutic implications. Endocrinology, 2006. 147(5): p. 2122-6.

45. Navarro VM, et al. Characterization of the potent luteinizing hormonereleasing activity of KiSS-1 peptide, the natural ligand of GPR54. Endocrinology, 2005. 146(1): p. 156-63.

46. Franceschini I, et al. Kisspeptin immunoreactive cells of the ovine preoptic area and arcuate nucleus co-express estrogen receptor alpha. Neurosci Lett, 2006. 401(3): p. 225-30.

47. Smith JT, et al. Kiss1 neurons in the forebrain as central processors for generating the preovulatory luteinizing hormone surge. $J$ Neurosci, 2006. 26(25): p. 6687-94. 
48. Goodman RL., et al. Kisspeptin neurons in the arcuate nucleus of the ewe express both dynorphin A and neurokinin B. Endocrinology, 2007. 148(12): p. 5752-60.

49. Roseweir AK, Millar RP. The role of kisspeptin in the control of gonadotrophin secretion. Hum Reprod Update, 2009. 15(2): p. 203-12.

50. Smith JT, et al. Regulation of Kiss1 gene expression in the brain of the female mouse. Endocrinology, 2005. 146(9): p. 3686-92.

51. Smith JT, et al. Differential regulation of KiSS-1 mRNA expression by sex steroids in the brain of the male mouse. Endocrinology, 2005. 146(7): p. 2976-84.

52. Rometo AM, et al. Hypertrophy and increased kisspeptin gene expression in the hypothalamic infundibular nucleus of postmenopausal women and ovariectomized monkeys. J Clin Endocrinol Metab, 2007. 92(7): p. 2744-50.

53. Shibata M, et al. Evidence that down regulation of hypothalamic KiSS-1 expression is involved in the negative feedback action of testosterone to regulate luteinising hormone secretion in the adult male rhesus monkey (Macaca mulatta). J Neuroendocrinol, 2007. 19(6): p. 432-8.

54. Adachi S, et al. Involvement of anteroventral periventricular metastin/kisspeptin neurons in estrogen positive feedback action on luteinizing hormone release in female rats. J Reprod Dev, 2007. 53(2): p. 367-78.

55. Seminara SB, et al. Genetics of hypogonadotropic hypogonadism. J Endocrinol Invest, 2000. 23(9): p. 560-5.

56. Semple RK, et al. Two novel missense mutations in $\mathrm{g}$ protein-coupled receptor 54 in a patient with hypogonadotropic hypogonadism. J Clin Endocrinol Metab, 2005. 90(3): p. 1849-55. 
57. Lanfranco $F$, et al. Role of sequence variations of the $\mathrm{GnRH}$ receptor and $G$ protein-coupled receptor 54 gene in male idiopathic hypogonadotropic hypogonadism. Eur J Endocrinol, 2005. 153(6): p. 845-52.

58. Tenenbaum-Rakover $\mathrm{Y}$, Commenges-Ducos M, lovane A, Aumas C, Admoni $\mathrm{O}$, de Roux $\mathrm{N}$. Neuroendocrine phenotype analysis in five patients with isolated hypogonadotropic hypogonadism due to a L102P inactivating mutation of GPR54. J Clin Endocrinol Metab, 2007. 92(3): p. 1137-44.

59. Teles MG, et al. A novel homozygous splice acceptor site mutation of KISS1R in two siblings with normosmic isolated hypogonadotropic hypogonadism. Eur J Endocrinol, 2010. 163(1): p. 29-34.

60. Teles MG, et al. A GPR54-activating mutation in a patient with central precocious puberty. $N$ Engl J Med, 2008. 358(7): p. 709-15.

61. Silveira LG, et al. Mutations of the KISS1 gene in disorders of puberty. J Clin Endocrinol Metab. 95(5): p. 2276-80.

62. Harms JF, Welch DR, Miele ME. KISS1 metastasis suppression and emergent pathways. Clin Exp Metastasis, 2003. 20(1): p. 11-8.

63. Rechsteiner $M$, Rogers SW. PEST sequences and regulation by proteolysis. Trends Biochem Sci, 1996. 21(7): p. 267-71.

64. Roa J, et al. New frontiers in kisspeptin/GPR54 physiology as fundamental gatekeepers of reproductive function. Front Neuroendocrinol, 2008. 29(1): p. 48-69.

65. Sulem $P$, et al. Genome-wide association study identifies sequence variants on 6q21 associated with age at menarche. Nat Genet, 2009.

66. He C, et al. Genome-wide association studies identify loci associated with age at menarche and age at natural menopause. Nat Genet, 2009. 
67. Ong KK, et al. Genetic variation in LIN28B is associated with the timing of puberty. Nat Genet, 2009.

68. Perry JR, et al. Meta-analysis of genome-wide association data identifies two loci influencing age at menarche. Nat Genet, 2009.

69. Ambros V, Horvitz HR. Heterochronic mutants of the nematode Caenorhabditis elegans. Science, 1984. 226(4673): p. 409-16.

70. Guo $\mathrm{Y}$, et al. Identification and characterization of lin-28 homolog $\mathrm{B}$ (LIN28B) in human hepatocellular carcinoma. Gene, 2006. 384: p. 51-61.

71. Polesskaya A, Harel-Bellan A. [A novel role for an embryonic regulatory protein Lin-28 in adult skeletal muscle differentiation]. Med Sci (Paris), 2007. 23(10): p. 796-7.

72. Yang $\mathrm{DH}$, Moss EG. Temporally regulated expression of Lin-28 in diverse tissues of the developing mouse. Gene Expr Patterns, 2003. 3(6): p. 719-26.

73. Ermolenko DN, Makhatadze GI. Bacterial cold-shock proteins. Cell Mol Life Sci, 2002. 59(11): p. 1902-13.

74. Moss EG, Lee RC, Ambros V, The cold shock domain protein LIN-28 controls developmental timing in $\mathrm{C}$. elegans and is regulated by the lin4 RNA. Cell, 1997. 88(5): p. 637-46.

75. Ambros V. A hierarchy of regulatory genes controls a larva-to-adult developmental switch in C. elegans. Cell, 1989. 57(1): p. 49-57.

76. Euling S, Ambros V. Heterochronic genes control cell cycle progress and developmental competence of $\mathrm{C}$. elegans vulva precursor cells. Cell, 1996. 84(5): p. 667-76.

77. Ricarte Filho JC, Kimura ET. [MicroRNAs: novel class of gene regulators involved in endocrine function and cancer]. Arq Bras Endocrinol Metabol, 2006. 50(6): p. 1102-7. 
78. Heo I, et al. Lin28 mediates the terminal uridylation of let-7 precursor MicroRNA. Mol Cell, 2008. 32(2): p. 276-84.

79. Viswanathan SR, Daley GQ, Gregory RI. Selective blockade of microRNA processing by Lin28. Science, 2008. 320(5872): p. 97-100.

80. Wilhelm JE, et al. Isolation of a ribonucleoprotein complex involved in mRNA localization in Drosophila oocytes. J Cell Biol, 2000. 148(3): p. 427-40.

81. Kohno $\mathrm{K}$, et al. The pleiotropic functions of the $\mathrm{Y}$-box-binding protein, YB-1. Bioessays, 2003. 25(7): p. 691-8.

82. Mullen TE, Marzluff WF. Degradation of histone mRNA requires oligouridylation followed by decapping and simultaneous degradation of the mRNA both 5' to 3' and 3' to 5'. Genes Dev, 2008. 22(1): p. 50-65.

83. Hagan JP, Piskounova E, Gregory RI. Lin28 recruits the TUTase Zcchc11 to inhibit let-7 maturation in mouse embryonic stem cells. Nat Struct Mol Biol, 2009. 16(10): p. 1021-5.

84. Calin GA, et al. Human microRNA genes are frequently located at fragile sites and genomic regions involved in cancers. Proc Natl Acad Sci U S A, 2004. 101(9): p. 2999-3004.

85. Park SM, et al. Let-7 prevents early cancer progression by suppressing expression of the embryonic gene HMGA2. Cell Cycle, 2007. 6(21): p. 2585-90.

86. $\mathrm{Yu} \mathrm{J}$, et al. Induced pluripotent stem cell lines derived from human somatic cells. Science, 2007. 318(5858): p. 1917-20.

87. Marshall WA, Tanner JM. Variations in pattern of pubertal changes in girls. Arch Dis Child, 1969. 44(235): p. 291-303.

88. Marshall WA, Tanner JM. Variations in the pattern of pubertal changes in boys. Arch Dis Child, 1970. 45(239): p. 13-23. 
89. Greulich WW PS. Radiographic atlas of skeletal development of the hand and wrist. 2nd ed, ed. 1959., Stanford.: Stanford University Press.

90. Brito VN, et al. Diagnostic value of fluorometric assays in the evaluation of precocious puberty. J Clin Endocrinol Metab, 1999. 84(10): p. 3539-44.

91. Lee PA. Laboratory monitoring of children with precocious puberty. Arch Pediatr Adolesc Med, 1994. 148(4): p. 369-76.

92. Brito $\mathrm{VN}$, et al. A single luteinizing hormone determination 2 hours after depot leuprolide is useful for therapy monitoring of gonadotropindependent precocious puberty in girls. J Clin Endocrinol Metab, 2004. 89(9): p. 4338-42.

93. Piskounova $\mathrm{E}$, et al. Determinants of microRNA processing inhibition by the developmentally regulated RNA-binding protein Lin28. J Biol Chem, 2008. 283(31): p. 21310-4.

94. Luan X, et al. GPR54 polymorphisms in Chinese girls with central precocious puberty. Neuroendocrinology, 2007. 86(2): p. 77-83.

95. Luan X, et al. Association study of the polymorphisms in the KISS1 gene with central precocious puberty in Chinese girls. Eur J Endocrinol, 2007. 157(1): p. 113-8.

96. Bianco SD, et al. KISS1R intracellular trafficking and degradation: effect of the Arg386Pro disease-associated mutation. Endocrinology. 152(4): p. 1616-26.

97. ACS Reis AM, Castro M, Antonini SR. A Novel GPR54 Mutation in a Patient with Gonadotropin-Dependent Precocious Puberty. Endocrine Society's 92th Annual Meeting, 2010..

98. Morton N. Methods in Genetic Epidemiology. New York: Krager, 1983. 
99. Houang M, Roze C, Kaci FM, Yves LB, Carel JC, Leger J, de Roux N, KiSS 1 polymorphisms analysis in a cohort of patients with disorder in the timing of pubertal onset shows association between 3' UTR polymorphisms and central precocious puberty. Abstract in Hormone Research, Proceedings of the LWPES/ESPE 8th Joint Meeting, 2009. $72: 49$.

100. Mastronardi $\mathrm{C}$, et al. Deletion of the Ttf1 gene in differentiated neurons disrupts female reproduction without impairing basal ganglia function. J Neurosci, 2006. 26(51): p. 13167-79.

101. Mitchell DC, et al. Regulation of KiSS-1 metastasis suppressor gene expression in breast cancer cells by direct interaction of transcription factors activator protein-2alpha and specificity protein-1. J Biol Chem, 2006. 281(1): p. 51-8.

102. Li D, et al. Estrogen regulates KiSS1 gene expression through estrogen receptor alpha and SP protein complexes. Endocrinology, 2007. 148(10): p. 4821-8.

103. Reinhart BJ, et al. The 21-nucleotide let-7 RNA regulates developmental timing in Caenorhabditis elegans. Nature, 2000. 403(6772): p. 901-6.

104. Viswanathan SR, et al. Lin28 promotes transformation and is associated with advanced human malignancies. Nat Genet, 2009. 41(7): p. 843-8.

105. Medland SE, et al. A variant in LIN28B is associated with 2D:4D fingerlength ratio, a putative retrospective biomarker of prenatal testosterone exposure. Am J Hum Genet, 2010. 86(4): p. 519-25.

106. Zhu $\mathrm{H}$, et al. Lin28a transgenic mice manifest size and puberty phenotypes identified in human genetic association studies. Nat Genet, 2010. 42(7): p. 626-30. 
107. Medland SE, et al. A variant in LIN28B is associated with 2D:4D fingerlength ratio, a putative retrospective biomarker of prenatal testosterone exposure. Am J Hum Genet. 86(4): p. 519-25.

108. Zhu $\mathrm{H}$, et al. Lin28a transgenic mice manifest size and puberty phenotypes identified in human genetic association studies. Nat Genet. 42(7): p. 626-30.

109. Peng S, et al. Genome-wide studies reveal that Lin28 enhances the translation of genes important for growth and survival of human embryonic stem cells. Stem Cells. 29(3): p. 496-504.

110. Morton NE. Methods in Genetic Epidemiolgy. New York: Karger, 1983.

111. Durbin RM, et al. A map of human genome variation from populationscale sequencing. Nature. 467(7319): p. 1061-73.

112. Tommiska J, et al. LIN28B in constitutional delay of growth and puberty. J Clin Endocrinol Metab. 95(6): p. 3063-6. 